
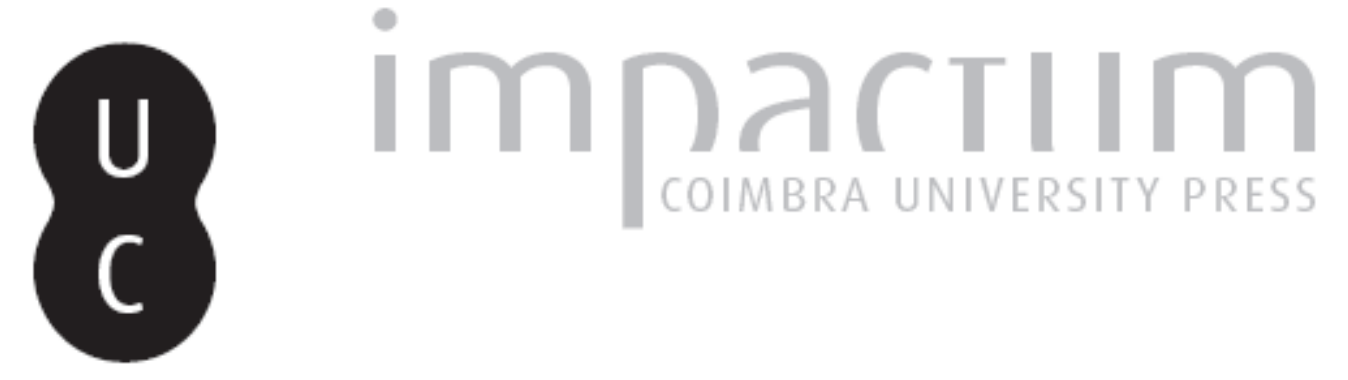

\title{
Inquisição, jesuítas e cristãos-novos em Portugal no século XVI
}

\author{
Autor(es): $\quad$ Marcocci, Giuseppe
}

Publicado por: Imprensa da Universidade de Coimbra

URL persistente:

URl:http://hdl.handle.net/10316.2/43699

DOI:

DOI:https://doi.org/10.14195/2183-8925_25_8

Accessed : $\quad$ 26-Apr-2023 16:21:08

A navegação consulta e descarregamento dos títulos inseridos nas Bibliotecas Digitais UC Digitalis, UC Pombalina e UC Impactum, pressupõem a aceitação plena e sem reservas dos Termos e Condições de Uso destas Bibliotecas Digitais, disponíveis em https://digitalis.uc.pt/pt-pt/termos.

Conforme exposto nos referidos Termos e Condições de Uso, o descarregamento de títulos de acesso restrito requer uma licença válida de autorização devendo o utilizador aceder ao(s) documento(s) a partir de um endereço de IP da instituição detentora da supramencionada licença.

Ao utilizador é apenas permitido o descarregamento para uso pessoal, pelo que o emprego do(s) título(s) descarregado(s) para outro fim, designadamente comercial, carece de autorização do respetivo autor ou editor da obra.

Na medida em que todas as obras da UC Digitalis se encontram protegidas pelo Código do Direito de Autor e Direitos Conexos e demais legislação aplicável, toda a cópia, parcial ou total, deste documento, nos casos em que é legalmente admitida, deverá conter ou fazer-se acompanhar por este aviso.

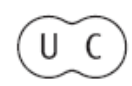



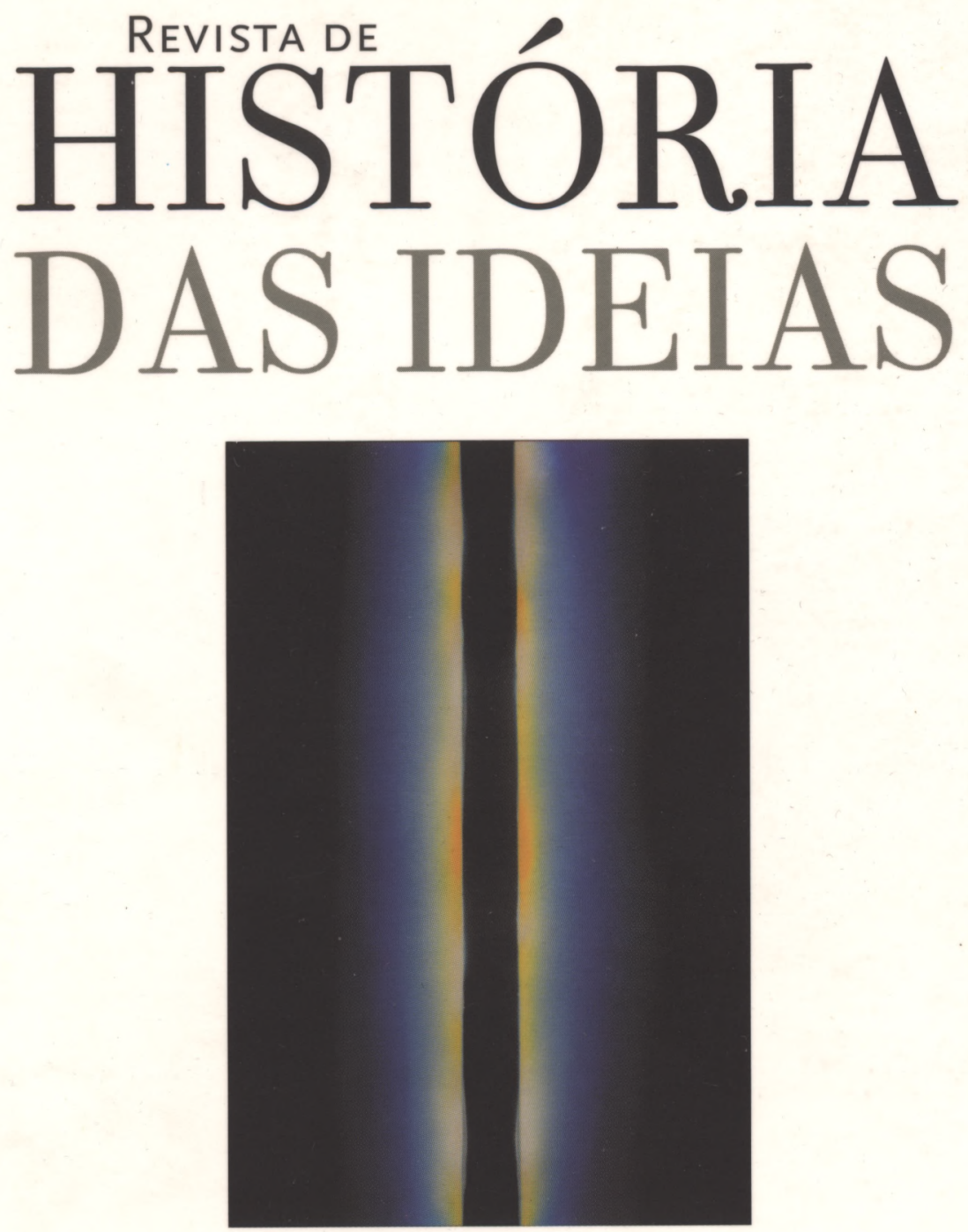

TOLERÂNCIAS, INTOLERÂNCIAS

\author{
Volume 25, 2004
}

INSTITUTO DE HISTÓRIA E TEORIA DAS IDEIAS

Faculdade de Letras da Universidade de CoImbra 


\section{INQUISIÇÃO, JESUÍTAS E CRISTÃOS-NOVOS EM PORTUGAL NO SÉCULO XVI**}

Os dois primeiros jesuítas, mestre Simão Rodrigues e Francisco Xavier, chegaram a Portugal em 1540, no mesmo ano em que em Lisboa se celebrou o primeiro auto-da-fé. A Inquisição tinha sido fundada pouco tempo antes, em 1536, procurando velar pela ortodoxia dos cristãos-novos, nome pelo qual eram designados os judeus que, em 1497, foram baptizados à força em Portugal, bem como os seus descendentes. Durante quase duzentos e cinquenta anos, o Sagrado Tribunal da Inquisição conseguiu impor-se como a principal autoridade eclesiástica no reino, exercendo um poder de controlo sobre a fé e de repressão da heresia, que se foi intensificando. A dura e demorada perseguição promovida pelo Santo Ofício contra os cristãos-novos tinha raízes num clima de intolerância anti-judaica, cada vez mais difundido na sociedade portuguesa que, naquela altura, módelava a sua própria identidade cultural e religiosa a partir de uma sólida obediência à ortodoxia católica romana.

A Companhia de Jesus, juntamente com a Inquisição, foi outra grande novidade entre as instituções eclesiásticas que, desde os meados do século XVI, participaram na definição de algumas características que marcaram

* Aluno do curso de aperfeiçoamento em disciplinas históricas da Scuola Normale Superiore de Pisa (Itália)

** Uma primeira versão deste ensaio foi apresentada e discutida na Faculdade de Letras da Universidade de Coimbra em Janeiro de 2004, durante uma sessão do seminário Inquisição e poder, dirigido pelo Prof. José Pedro Paiva. 
a sociedade portuguesa. Acolhidos favoravelmente na corte, onde foram adquirindo um peso político cada vez mais consistente, os jesuítas dedicaram-se, com êxito significativo, a diversas actividades, destacando-se a catequização pelo ministério da palavra e pela administração dos sacramentos, as obras de caridade e de pacificação social, a animação da vida espiritual dos fiéis, o empenho na instrução superior e universitária e as grandes missões de evangelização nas regiões extra-europeias. Durante a segunda metade do século XVI, depois de ultrapassadas algumas dificuldades iniciais, os jesuítas adquiriram enorme influência sobre a vida religiosa, cultural e também política do reino. Foi nesta época que as ligações entre o Santo Ofício e a Companhia de Jesus se tornaram cada vez mais intensas, até se estabelecer uma íntima relação de colaboração sistemática, que não teve comparação com nenhum outro país da Europa católica da época, onde, pelo contrário, as relações entre as duas instituições foram sempre bastante complexas e difíceis ${ }^{(1)}$.

A necessidade de reconstruir as relações que se verificaram entre a Inquisição e a Companhia fundada por Inácio de Loyola, foi afirmada recentemente no livro de Dauril Alden sobre a história da Companhia de Jesus em Portugal e no seu império colonial. Na opinião de Alden, os jesuítas desempenharam um papel muito maior nas operações do Santo Ofício do que a tradição historiográfica tem admitido ${ }^{(2)}$. A imagem duma ausência quase total de relações directas e orgânicas entre ambas as partes, com a notável excepção da obra de assistência aos condenados durante os autos-da-fé - sobre a qual sempre se insistiu muito -, surgiu a partir de, pelo menos, três razões: acima de tudo, devido à elevada conflitualidade entre as duas, durante o século XVII, que culminou com o dramático caso de António Vieira (1663-1667) e com a suspensão da Inquisição entre 1674 e $1681^{(3)}$; em segundo lugar, a tendência deliberada

(1) Para uma breve síntese, cf. John W. O' Malley, I Primi Gesuiti, Milano, Vita e Pensiero, 1999 [ed. or. em inglês, Cambridge (Mass.)-London 1993], pp. 341-352.

(2) Cf. Dauril Alden, The Making of an Enterprise. The Society of Jesus in Portugal, Its Empire, and Beyond, 1540-1750, Stanford (California), Stanford University Press, 1996, pp. 670-673.

(3) O primeiro episódio de choque entre a Companhia de Jesus e a Inquisição em Portugal no século XVII aconteceu no início da Restauração, quando o Santo Ofício de Évora processou o padre jesuíta Francisco Pinheiro (1642-1644). Sobre o caso ver Francisco Rodrigues, História da Companhia de Jesus na assistência de 
para reduzir notavelmente a importância de qualquer forma de colaboração activa entre jesuítas e inquisidores por parte de Francisco Rodrigues, o autor da principal obra de referência sobre a história da Companhia de Jesus em Portugal, publicada entre 1931 e $1950^{(4)}$; por fim, a proprensão da historiografia sobre a Inquisição portuguesa para estudar o Sagrado Tribunal como um objecto de análise isolado, sem considerar as suas ligações com as outras instituições, principalmente as eclesiásticas e, em particular, as ordens religiosas ${ }^{(5)}$. Tendo estratégias e métodos de inter-

Portugal, Porto, Livraria Apostolado da Imprensa, 1931-1950, 4 tomos em 7 vols.; em particular t. III, vol. 1, pp. 479-491; Pedro Lage Reis Correia, "O caso do padre Francisco Pinheiro: estudo de um conflito entre a Inquisição e a Companhia de Jesus no ano de 1643", Lusitania Sacra, 2a sér., vol. XI, 1999, pp. 295-322. Sobre a figura do padre António Vieira ver o clássico estudo de João Lúcio de Azevedo, História de António Vieira, Lisboa, Livraria Clássica Editora, $1992^{3}$ [1ª ed. 1918], 2 vols. Para a sua relação conflituosa com o Santo Ofício, cf. Francisco Rodrigues, $o b$. cit., t. III, vol. 1, pp. 445-477. O texto do processo inquisitorial de Vieira encontra-se publicado em Os Autos do Processo de Vieira na Inquisição, Edição, Transcrição, Glossário e Notas de Adma Fadul Muhana, São Paulo-Salvador (Bahia), Editora da Universidade Estadual Paulista-Fundação Cultural do Estado da Bahia, 1995. Sobre o papel dos jesuítas durante a crise do Santo Ofício desde o sacrilégio de Odivelas (1671) até o restabelecimento das funções ordinárias (1681) ver Francisco Rodrigues, ob. cit., t. III, vol. 1, pp. 491-502. Para outros aspectos ver João Lúcio de Azevedo, "Os Jesuítas e a Inquisição em conflito no século XVII", Boletim da Segunda Classe da Academia das Sciencias, vol. X, 1916, pp. 319-345; Isräel-Salvator Révah, "Les Jesuítes portugais contre l'Inquisition: la campagne pour la création de la Compagnie générale du commerce du Brésil", Revista do Livro, vol. XXXIV, 1956, pp. 29-53; agora em Idem, Études Portugaises, Paris, Fundação Calouste Gulbenkịan - Centro Cultural Português, 1975, pp. 155-183.

(4) Ver o tom das afirmações de Francisco Rodrigues, ob. cit., t. I, vol. 1, pp. 693-697; vol. 2, pp. 598-601; 625-627; t. II, vol. 1, pp. 150-155; 509-514. Nestas páginas o autor refere-se ao século XVI e procura defender a tese de que as relações entre o Santo Ofício e a Companhia de Jesus foram apenas episódicas e que os encargos inquisitoriais seriam um risco e um melindre para os jesuítas. A sua intenção dominante é a de manter separada a imagem histórica das duas instituições, distinguindo entre uma positiva e santa, a da Companhia, e outra negativa e cruel, a da Inquisição.

(5) Uma excepção é constituída por dois recentes artigos sobre as relações entre os bispos e a Inquisição durante o século XVI: cf. o meu "'Catequização pelo medo'? Inquisitori, vescovi e confessori di fronte ai 'nuovi cristiani' nel Portogallo del Cinquecento", em Le inquisizioni cristiane e gli Ebrei, Roma, Atti dei Convegni Lincei, 2003, pp. 123-193; José Pedro Paiva, “Os bispos e a Inquisição 
venção diferentes dos da Inquisição, as ordens religiosas - e a Companhia de Jesus foi um claro exemplo disso - auxiliaram o Santo Ofício de várias formas, oferecendo competências e ampliando o raio de acção do tribunal da fé para direç̧ões em que este, de outro modo, dificilmente se poderia encaminhar.

A relação peculiar que se estabeleceu entre a Inquisição e os jesuítas entende-se à luz de factores que não são exclusivamente religiosos, mas também, em boa parte, políticos, que tentarei evidenciar nas páginas seguintes. O estudo das ligações entre a Companhia de Jesus e o Santo Ofício não pode, porém, ficar separado da questão da presença na sociedade portuguesa da minoria discriminada, mas muito influente, dos cristãos-novos. Sente-se a falta dum estudo de conjunto sobre as dinâmicas concretas da discriminação e da segregação dos cristãos-novos e sobre a aplicação dos estatutos de limpeza de sangue ${ }^{(6)}$. Esta ausência dificulta ainda mais a compreensão dos elementos de continuidade e de diferenciação existentes entre as posições da Inquisição e das outras instituições eclesiásticas em relação ao problema dos cristãos-novos. Contudo, o caso da Companhia de Jesus em Portugal, e em toda Península Ibérica, foi já objecto de numerosos estudos que permitem, com o auxílio de nova documentação, observar como tempos e modos de colaboração entre os inquisidores e os jesuítas foram intimamente entrelaçados com os ásperos choques que existiram durante o século XVI na vida interna da província lusitana da Companhia. Entre estes choques deve-se destacar a questão da admissão de noviços cristãos-novos e das formas de discriminação a

portuguesa (1536-1613)”, Lusitania Sacra, 2a sér., vol. XV, 2003, pp. 43-76. Sobre as ordens religiosas ver a recente comunicação intitulada Os dominicanos e a Inquisição em Portugal (1536-1614), apresentada por José Pedro Paiva no Congresso internacional Los Dominicos y la Inquisición en España, Portugal y América, organizado pelo Instituto Histórico Dominicano (Roma) e realizado em Sevilha, em Março de 2004. Agradeço ao autor por me ter possibilitado a leitura do texto da sua intervenção antes da publicação.

(6) Sobre Espanha ver o clássico estudo de Albert A. Sicroff, Los estatutos de limpieza de sangre. Controversias entre los siglos XV y XVII, Madrid, Taurus Ediciones, 1985 [ed. or. em francês, Paris 1960]. Com especial referência à Companhia de Jesus face à questão da limpeza de sangue, cf. ibidem, pp. 315-343. Para o caso português a obra de referência é ainda João Lúcio de Azevedo, História dos cristãos novos portugueses, Lisboa, Livraria Clássica Editora, $1975^{2}$ [1 $1^{\mathrm{a}}$ ed. 1921]. 
que foram sujeitos alguns padres que tinham ascendência judaica ${ }^{(7)}$. Consequentemente, o presente estudo pretende tratar dos problemas surgidos, no século XVI, no quadro da complexa relação entre a Inquisição, os jesuítas e os cristãos-novos.

\section{Os primórdios da Companhia de Jesus em Portugal}

ACompanhia de Jesus estabeleceu-se em Portugal em 1540. Os primeiros padres fixaram-se em Lisboa e logo tiveram acesso à corte régia, onde gozaram de amplo favor e influência junto da família real e da nobreza como confessores e directores de exercícios espirituais ${ }^{(8)}$. Logo em 1541

(7) Para uma síntese geral ver John W. O'Malley, ob. cit., pp. 208-212 e a bibliografia citada nas pp. 460-461. Sobre o caso da província lusitana ver Francisco Rodrigues, ob. cit., t. II, vol. 1, pp. 336-361. O autor prolongou nas suas páginas os prejuízos da corrente segregacionista da Companhia contra os cristãos-novos ao afirmar que "a mistura de tal gente na sociedade portuguesa, naquêle século XVI, quase a podemos classificar de calamidade nacional" (p. 336). Sobre as relações entre a Companhia de Jesus e os cristãos-novos na Península Ibérica, com especial referência ao caso português, ver também: Isräel-Salvator Révah, "Les origines juives de quelques Jésuites hispano-portugais du XVIe siècle", em Etudes ibériques et latino-américaines: IV Congrès des Hispanistes français, Paris, Presses Universitaires de France, 1968, pp. 87-96; António Borges Coelho, "Tradição e mudança na política da Companhia de Jesus face à comunidade dos cristãos-novos", Revista de História, Centro de História da Universidade do Porto, vol. X, 1990, pp. 87-94; Francisco de Borja Medina, "Ignacio de Loyola y la 'limpieza de sangre'", em Juan Plazaola (Ed.), Ignacio de Loyola y su tiempo, Congresso Internacional de Historia (9-13 Setiembre 1991), Bilbao, Ediciones Mensajero, 1992, pp. 579-615; Pierre-Antoine Fabre, "La conversion infinie des Conversos. Des 'nouveaux-chrétiens' dans la Compagnie de Jésus au $16^{\mathrm{e}}$ siècle", Annales HSS, vol. LIV, 1999, pp. 875-893.

(8) Sobre os primeiros anos da Companhia de Jesus em Portugal ver Francisco Rodrigues, ob. cit., t. I, vol. 1, pp. 217-256; Marcel Bataillon, "L'implantation de la Compagnie de Jésus au Portugal", em Idem, Études sur le Portugal au temps de l'Humanisme, Paris, Fundação Calouste Gulbenkian-Centro Cultural Português, $1974^{2}$ [1 $1^{\mathrm{a}}$ ed. 1952], pp. 221-224; José Carlos Monteiro Pacheco, Simão Rodrigues. Iniciador da Companhia de Jesus em Portugal, Braga-São Paulo, Editorial A. O.-Edições Loyola, 1987, pp. 79-139. Sobre o favor de que gozaram os jesuítas na corte ver Ricardo García Villoslada, Sant'Ignazio di Loyola, Cinisello Balsamo, Edizioni Paoline, 1990 [ed. or. Madrid 1986], pp. 714-716; António Lopes, "Ignace de Loyola, 
mestre Simão Rodrigues obteve para a Companhia uma casa em Lisboa, graças à concessão, por parte do rei D. João III e da rainha D. Catarina, do mosteiro de S. Antão, no bairro da Mouraria. No ano seguinte, foi fundado o colégio de Coimbra. Contudo, não faltava quem olhasse os jesuítas com desconfiança, como o infante D. Henrique, que naquela altura já exercia o cargo de inquisidor mor, o qual pelos meados dos anos quarenta mandou fazer dois inquéritos sobre a Companhia ${ }^{(9)}$. Os motivos de suspeita de D. Henrique eram, fundamentalmente, dois. Primeiro, os contornos da espiritualidade jesuítica, em relação à qual alguns sectores eclésiasticos continuavam a ter reservas, devido aos processos a que, anos antes, fora sujeito Inácio de Loyola em Espanha - reservas amplificadas em Portugal pelo envolvimento de dois padres Jesuítas, o espanhol Alfonso Cipriano e o português Gonçalo de Medeiros, no processo inquisitorial contra a beata Isabel Fernandes, acusada de alumbradismo em $1544^{(10)}$. O padre Cipriano foi proibido pelo mestre

François Xavier et Jean III du Portugal", em Juan Plazaola, ob. cit., pp. 636-682; John W. O'Malley, ob. cit., p. 81; Dauril Alden, ob. cit., pp. 24-28. A acção dos padres da Companhia como confessores na corte foi analisada por João Francisco Marques, "Os Jesuítas, confessores da corte portuguesa na época barroca", Revista da Faculdade de Letras-História, $2^{a}$ sér., vol. XII, 1995, pp. 231-270; Idem, "Confesseurs des princes, les jésuites à la Cour de Portugal", em Les jésuites à l'âge baroque (1540-1640), sous la direction de Luce Giard et Louis de Vaucelles, Grenoble, Jérôme Millon, 1996, pp. 213-228.

(9) Sobre as iniciais suspeitas de D. Henrique, que mesmo Francisco Rodrigues tenta negar (cf. ob. cit., t. I, vol. 2, pp. 607-609), já insistira Baltasar Teles, Chronica da Companhia de Iesu, na provincia de Portugal; e do que fizeram, nas conquistas d'este Reyno, os Religiosos, que na mesma Provincia entràram, nos annos em que viveo S. Ignacio de Loyola, nosso Fundador, parte I, Lisboa, Paulo Craesbeeck, 1645, p. 511. Ver também José Carlos Monteiro Pacheco, ob. cit., pp. 123-124.

(10) No fim do segundo processo inquisitorial celebrado contra Isabel Fernandes, entre 1571 e 1573, encontram-se também algumas folhas pertencentes ao primeiro, que teve lugar no Santo Ofício de Lisboa, em 1544; ver Arquivo Nacional da Torre do Tombo (daqui em frente abreviado em ANTT), Inquisição de Lisboa, processo 9287, fls. 132-141. Numa anotação sucessiva, provavelmente escrita na altura do segundo processo, lê-se: "Nam vam aqui as testemunhas por onde então foi presa Isabel Fernandez por que se nam acharão, somente estas preguntas com este despacho dos Inquisidores" (fl. 132). De facto, o fascículo contém alguns interrogatórios feitos entre Março e Outubro de 1544 (fls. 132-140) e a sentença final, publicada pela Inquisição no dia 24 de Dezembro de 1544 (fl. 141). Na sessão 
Simão Rodrigues de contactar Isabel Fernandes e no dia 20 de Março de 1544 o jesuíta espanhol chegou a ser mandado chamar pelo inquisidor dominicano Jorge de Santiago para dar esclarecimentos sobre o tipo de relações que tivera com a processada ${ }^{(11)}$. O segundo elemento que induzia

de 18 de Março Isabel Fernandes, ao ser perguntada pela identidade dos seus directores espirituais, mencionou, entre outros, dois "padres de Roma", o "mestre Ceprano" e o "mestre Gonçalo" (fl. 132), que José Sebastião da Silva Dias não hesitou em identificar correctamente com os padres jesuítas Alfonso Cipriano e Gonçalo de Medeiros (ver Correntes do sentimento religioso em Portugal (séculos XVI-XVIII), Coimbra, Instituto dos Estudos Filosóficos da Universidade de Coimbra, 1960, p. 599; mais em geral, acerca da figura e dos processos de Isabel Fernandes ver ibidem, pp. 375-381;600-601). O problema dos confessores de Isabel Fernandes foi também referido na sentença final do processo de 1544, em que se assentou que "se confesara todalas vezes que tiver devação ao confesor que lhe sera nomeado no mosteiro de Sam Dominguos, e com seu conselho podera tomar - Santo Sacramento e doutra maneira nam" (em ANTT, Inquisição de Lisboa, processo 9287, fl. 141). Pelos interrogatórios do segundo processo depreende-se que o primeiro dominicano nomeado para ser confessor foi frei João da Cruz, mas depois de oito dias o cargo passou a ser exercido durante um ano e meio por frei Jorge de Santiago, um dos inquisidores que tinham assinado a sentença de Isabel Fernandes. De facto, é um exemplo de como a Inquisição continuava a manter o controlo sobre a ortodoxia duma penitenciada através da confissão sacramental. Entre os confessores de Isabel Fernandes que seguiram o inquisidor dominicano contam-se também alguns jesuítas, entre os quais o padre Gonçalo Vaz de Melo. Ver a sessão de 10 de Outubro de 1571, ibidem, fl. 12 ro da segunda numeração; sobre Gonçalo Vaz de Melo, ver a sessão de 16 de Setembro de 1572, ibidem, fls. 83-84.

(11) Na sessão de 24 de Março Isabel Fernandes foi "preguntada se dispois de dito tempo que começou a comungar cada dia alguum padre frequentara sua casa imdo a praticar com ella em cousas de noso Senhor, dise que si que huum padre de Sam Aõtam que chamão Ceprano foi alla por vezes e não se acorda bem por quanto tempo contenuaria ir a sua casa mas que lhe parece que seria por huum mes pouco mães ou menos no qual tempo hia amiude por que elle a comungava polla menhaã e à tarde a hia a ver e que por lho mestre Simão difimder leixara de ir a sua casa", ibidem, fl. 135v. Na fl. 137 encontra-se o testemunho do padre Alfonso Cipriano, que quatro dias antes, a 20 de Março, tinha sido convocado pelo inquisidor de Lisboa, frei Jorge de Santiago. Frente ao dominicano, o confessor jesuíta tinha procurado defender a ortodoxia de Isabel Fernandes. Trata-se de um documento de considerável interesse, sobre o qual já chamou atenção José Sebastião da Silva Dias (ob. cit., p. 605) e que se acha publicado integralmente no apêndice deste artigo. 
D. Henrique a ter reservas para com os jesuítas era a disponibilidade da Companhia em admitir cristãos-novos ${ }^{(12)}$. A este último ponto tentou remediar o provincial Simão Rodrigues com um breve regimento, composto entre o 1546 e 1550, em que se davam as regras para admissão dos noviços na Companhia. Depois do preâmbulo, declarava-se: "Os que por inspiração devina pedirem ser reçebidos no collegio pera no instituto da Companhia servirem a seu Deos e Senhor, serão examinados das cousas seguintes; e se em alguma dellas forem comprendidos, não se receberão; e se o negarem, em todo tempo que se souber, serão lançados fora". Acrescente-se que entre as regras que justificavam a recusa de um candidato e autorizavam os superiores, caso descobrissem uma declaração falsa, a expulsar da Companhia um noviço admitido, a terceira dizia: "Se por alguma via descende de christãos novos. Se ha tido openiao, polla qual aja sido reprovado por ereje ou conhecido pubricamente por tal"(13). A equiparação entre cristãos-novos e hereges era manifesta neste regimento. Mas, de facto, as regras do provincial não entraram em funções e a Companhia continuou a aceitar noviços cristãos-novos.

O problema da admissão de cristãos-novos na Companhia era muito sentido, sobretudo na Península Ibérica, onde era maior a discriminação para com as pessoas de origem judaica ou moura. Alguns dos principais jesuítas, como Diego Laínez e Juan Alfonso de Polanco, eram mesmo cristãos-novos. Aliás, o fundador e primeiro geral da Companhia, Inácio de Loyola, sempre manteve uma posição de abertura para com os cristãos-novos, opondo-se a disposições de discriminação racial - naquela época uma questão de procedência socio-religiosa -, apesar de encomendar a máxima prudência ${ }^{(14)}$. Todavia, as inquirições não deviam ser muito aprofundadas, pelo que numerosos cristãos-novos puderam dar entrada na Companhia, encobrindo a própria identidade, como, provavelmente,

(12) Ver ibidem, pp. 174-175.

(13) Modo que se ha-de ter nos collegios da Companhia en o reçeber dos estudantes d'ella, publicado em "Monumenta Historica Societatis Iesu" (daqui em frente abreviado em "MHSI"), Epistolae PP. Paschasii Bröeti, Claudii Jaji, Joannis Codurii et Simonis Roderici, Madrid 1903, pp. 859-861. Sobre o documento ver ibidem, p. 449; Francisco Rodrigues, ob. cit., t. I, vol. 1, p. 487; t. II, vol. 1, p. 338; Isräel-Salvator Révah, "Les origines" cit., p. 88. Francisco de Borja Medina, ob. cit., pp. 592-593.

(14) Ver ibidem, pp. 594-601. 
fez Manuel Lopes, um jovem cristão-novo, aceite no colégio de Coimbra, em $1545^{(15)}$. A linha de mestre Simão, partilhada também, ao que parece, por Francisco Xavier, não conseguiu impor-se oficialmente em Portugal ${ }^{(16)}$. Mas o aparecimento, desde os anos quarenta, duma corrente segregacionista entre os jesuítas portugueses, e ainda para mais apoiada pelo padre provincial, por um lado, mitigava as posições de $\mathrm{D}$. Henrique e do Santo Ofício para com a Companhia, por outro, causava fortes tensões e contrastes no interior da província lusitana.

Durante os anos Quarenta, outro factor contribuiu para a superação das iniciais dúvidas do inquisidor mor em relação aos jesuítas. Refiro-me à intervenção de Inácio a favor das pretensões da corte portuguesa no negócio da Inquisição que então se tratava em Roma. O zelo do fundador da Companhia é atestado por muitos documentos, como, por exemplo, a carta escrita a mestre Simão Rodrigues, no dia 28 de Julho de 1542, onde se lê: "[...] hablé a S. S. asaz largo, y en su cámara á solas, informándole de los grandísimos errores y grandísimas neçesidades de los nuebos xpianos, contándole cómo se yban á labar al pozo, etc., segund que me escrivistes largo sobre ello: asímismo instando, y poniendo las mejores razones, que yo podia hallar en el Señor nuestro, para moverle á la expedicçión del negoçio de la santa inquisiçión"(17).

(15) Sobre o caso de Manuel Lopes ver Isräel-Salvator Révah, "Les origines" cit., pp. 87-88.

(16) Sobre as posições de Francisco Xavier ver Francisco de Borja Medina, ob. cit., pp. 587-589.

(17) Carta do padre geral Inácio de Loyola ao padre mestre Simão Rodrigues, Roma, 28 de Julho de 1542, publicada em "MHSI", Monumenta Ignatiana. Sancti Ignatii de Loyola Societatis Jesu fundatori epistolae et instructions (daqui em diante MI Epp), 12 vols., Madrid, 1903-1911; vol. I, pp. 220-223. Ver também: carta do padre geral Inácio de Loyola ao infante D. Henrique, Roma, 16 de Julho de 1542, ibidem, pp. 214-215; carta do infante D. Henrique ao padre geral Inácio de Loyola, Lisboa, 28 de Maio de 1542, ibidem, pp. 215-216; carta do padre geral Inácio de Loyola ao padre mestre Simão Rodrigues, Roma, 28 de Julho de 1542, ibidem, pp. 216-220; carta do padre geral Inácio de Loyola ao padre mestre Simão Rodrigues, Roma, 17 de Agosto de 1542, ibidem, pp. 223-226; carta do rei D. João III ao padre geral Inácio de Loyola, sem data, mas escrita no mês de Agosto de 1545, em Corpo Diplomatico Portuguez contendo os actos e relações politicas $e$ diplomaticas de Portugal com as diversas potencias do mundo desde o século XVI, 11 tomos, Lisboa, Typographia da Academia Real das Sciencias, 1862-1898, t. V, 
O apoio de Inácio foi um dos elementos decisivos que levaram o Papa Paulo III a conceder, em 1547, a bula Meditatio cordis, em virtude da qual se restabeleceram e se aumentaram os poderes do Santo Ofício.

Nos primeiros anos as relações entre a Inquisição e a Companhia de Jesus eram ainda oscilantes. Por um lado, Inácio de Loyola tinha ajudado a causa do Santo Ofício em Roma e entre os jesuítas portugueses tinha aparecido uma notável tendência segregacionista mas, por outro lado, era um facto irrefutável que não funcionava nenhuma forma de vigilância sobre o ingresso de cristãos-novos na Companhia, assim como se perpetuavam graves suspeitas sobre as modalidades da espiritualidade jesuítica. Além disso, entre o fim dos anos quarenta e o início dos cinquenta, quando a Inquisição era ainda uma instituição bastante frágil, semelhante a um organismo com cabeça grande e corpo pequeno, a Companhia de Jesus podia parecer um possível concorrente, por causa das faculdades especiais que, por privilégio pontifício, tinham alguns padres jesuítas. Entre elas contava-se o poder de absolver de qualquer delito de heresia no foro da consciência ${ }^{(18)}$. Este privilégio, que sempre causara atritos nas áreas onde havia Inquisição, fazia parte de uma série de poderes transmitidos oralmente pelo Papa Paulo III a Inácio. Em 1551, o Papa Júlio III confirmaria o privilégio vivae vocis oraculo ao padre Alfonso Salmerón, na presença do dominicano Ambrogio Catarino Politi(19). Por fim, em 1552, Júlio III enviou um breve a Inácio em que renovou o poder de absolvição no foro da consciência já outorgado à Companhia ${ }^{(20)}$. Aliás, já no mês de

pp. 454-455. Sobre o papel de mediador de Inácio de Loyola no negócio da Inquisição portuguesa ver Ludwig von Pastor, Storia dei Papi dalla fine del Medio Evo, vol. V, Roma, Desclée e C. ', 1924, pp. 382-385; José Luis González Novalin, "La Inquisición y la Compañia de Jesús", Anthologica Annua, vol. XXXVII, 1990, pp. 11-56; em particular pp. 23-24; John W. O'Malley, ob. cit., p. 343. Ver também Francisco Rodrigues, ob. cit., t. I, vol. 1, pp. 598-601; este autor, todavia, tenta reduzir as implicações do envolvimento do geral da Companhia no negócio da Inquisição portuguesa, declarando: "Tôda essa actividade porém do santo fundador era sobretudo uma simpática manifestação dos finos sentimentos que nutria para o insigne bemfeitor da sua Ordem [scil. o rei D. João III]" (p. 601).

(18) Ver John W. O' Malley, ob. cit., pp. 159; 343-344.

(19) Ver "MHSI", P. Hieronymi Nadal Commentarii de Instituto Societatis Iesu, Roma, 1962, p. 351, nota 18.

(20) Ver o breve Sacrae Religionis, Roma, 22 de Outubro de 1552, publicado em Institutum Societatis Iesu, vol. I, Bullarium et Compendium Privilegiorum, Florentiae, ex Typographia a SS. Conceptione, 1892, pp. 28-31. Depois de ter confirmado os 
Maio de 1551, Inácio tinha conferido a faculdade de absolver de heresia a uma trintena dos principais padres jesuítas, a maioria dos quais eram portugueses ou moravam ou eram destinados a morar em Portugal ${ }^{(21)}$.

privilégios já concedidos à Companhia, o breve continuava assim: "ac quoscumque a casibus haeresis et aliis contra fidem, et consequentibus censuris quibuscumque, etiam per te et successores tuos vel alios similiter Professos ad id idoneos, per te et pro tempore existentem Praepositum Generalem Societatis huiusmodi deputandos, absolvendi, et, quatenus opus sit, in foro conscientiae dispensandi, per fel. rec. Paulum Papam III, praedecessorem Nostrum et per Nos, tam in genere quam in specie, et alias quomodolibet et sub quibuscumque tenoribus et formis concessa, eorum omnium tenores et causas propter quas concessa sunt, praesentibus pro sufficienter expressis habentes, apostolica auctoritate, ex certa Nostra scientia, tenore praesentium approbamus et confirmamus, ac illis perpetuae et inconcussae firmitatis robur adiicimus" (pp. 28-29).

(21) Ver "MHSI", MI Epp., vol. III, pp. 475-477: "Ignatius de Loyola, Societatis Jesu praepositus generalis. Charissimo in Christo fratri Ambrosio Perez, sacerdoti eiusdem Societatis, salutem in Domino sempiternam. Cum probata nobis sit tuae vitae integritas, doctrina et studium illum charitatis, quo animarum salutem iuvare pro virili parte curas, ad Dei gloriam et communem utilitatem fore confidimus, si arma illa spiritualia, quae nobis apostolica sedes dispensanda tribuit, etiam circa heresis casus, in bulla, quae legi in cena Domini consuevit, reservatos, comittamus. Simul ergo cum omnibus aliis gratiis et facultatibus, Societatis nostrae quocunque modo per praepositi generalis dispositionem concessis, quae privatis fratribus nostris usui esse possunt (praeterquam de legendis libris haereticis), hanc etiam absolvendi a quibusvis casibus ad haeresim pertinentibus, in foro conscientiae tantum, tibi in nomine Patris, et Filii, et Spiritus Sancti conferimus; precarumque Deum altissimum, ut tibi hac authoritate ad aedificationem animarum et ipsius laudem uti perpetuo concedat. Datum Romae XXII Maii 1551. In margine. Pro Ambrosio Perez. De Absolutione a casibus haeresis. Similis pro Francisco Palmio. Similis pro Anthonio Brandon. Similis pro Ludovico Gonzalez. Similis pro Ludovico de Grana. Similis pro Urbano. Similis pro Joanne de San Miguel. Similis pro domino Gonzalo de Silveira. Similis pro Gonzalo Vaaz. Similis pro Joanne Nunnez. Similis pro Melchiore Ludovice. Similis pro Manuele Godiño. Similis pro Joanne de Aragon. Similis pro magistro Gonzalo. Similis pro Lupo Leyton. Similis, dempta tamen restrictione librorum hereticorum, pro Magistro Simone. Similis doctori Antonio [scil. Michäeli] de Torres. Similis Francisco de Strada. Similis Joanni Gonzalez, praepositi Valisoleti. Similis Francisco de Villanova, rectori collegii complutensis. Similis praeposito barchinonensi. Similis valentino. Similis caesaraugustano. Similis gandiensi. Similis superioribus Antonio Perez. Similis Petro Diez, portugalensi. De dispensatione circa ieiunia Mag. Andreae Frusio, similis praecedentibus. De absolutione haereticorum, eidem. Similes duae rectori paduano". 
Tratava-se dum poder que, provavelmente, tinha sido criado para ser usado em situações extraordinárias, nas regiões do Norte da Europa conquistadas pela Reforma ou nas terras dos infiéis, onde os jesuítas actuavam como missionários ${ }^{(22)}$. Mas depois de concedido, era muito difícil controlar a faculdade de absolvição que podia ser usada também em países onde actuava o Santo Ofício, como aconteceu em Espanha, onde surgiram por isso violentas polémicas ${ }^{(23)}$.

Pouco se sabe acerca da aplicação concreta deste poder em Portugal. Pelo carácter essencialmente oral duma prática que se cumpria no segredo do foro da consciência é muito raro encontrar rastos documentais do

(22) Por exemplo, já em 1551, havia entre os jesuítas quem tentasse limitar o privilégio da Companhia em Espanha: "illis in regnis [scil. Hispaniae] propter auctoritatem Sancti Officii Inquisitionis moderatissime illa utendum esse prudentes existimabant; nam aegre ferre Inquisitores videbantur aliis quam ipsis facultatem eam concedi" (em "MHSI", Juan Alfonso de Polanco, Vita Ignatii Loiolae et rerum Societatis Jesu historica [Chronicon] (daqui em frente abreviado em Chron.), 6 vols., Madrid, 1894-1898; vol. II, p. 354. E em carta escrita de Roma, no dia 11 de Abril de 1553, pelo padre geral Inácio de Loyola aos padres prepósitos dos colégios de Espanha, lê-se: "esta será solo pera advertiros de lo que nos ha parecido en el Señor nuestro á mayor alabanza y gloria de su divina magestad acerca de la facultad y grazia que S. S. nos ha concedido, como vereis por el breve auténtico que os embiamos, para absolver in foro conscientiae de casos de heresias; $y$ es, que por justos y debidos respectos os encargamos, que en ninguna manera los nuestros de esos reynos usen de esta gracia, aunque usen y gocen de las otras todas" (publicada em "MHSI", MI Epp., vol. V, pp. 8-9). Alguns anos depois, o padre Jeronimo Nadal insistiu de maneira muito explícita no assunto na Plática quinta das Exhortationes Complutenses (1561): "También tenemos privilegio en una bulla de Julio $3^{\circ}$. de absolver de heregía in foro interiori, pero nosotros interpretamos la voluntad del Papa, que es que favorezcamos en todo a la Inquisición, como os dixe ser de nuestro instituto; y assì no usamos ni usaremos de esta gracia en España, porque no conviene para el fin dicho. En otras partes, como en Alemania, donde este crimen es más ordinario y no ay perjuizio a otros, puédese usar y se usa deste privilegio, porque allí conviene para el fin que la Compañia pretende" (em "MHSI", P. Hieronymi Nadal Commentarii cit., pp. 351-352).

(23) Sobre o caso de Espanha ver Stefania Pastore, "Esercizi di carità, esercizi di Inquisizione. Siviglia, 1558-1564", Rivista di Storia e Letteratura Religiosa, vol. XXXVII, 2001, pp. 231-258; em particular pp. 249-252; Eadem, Il Vangelo e la spada. L'Inquisizione di Castiglia e i suoi critici (1460-1598), Roma, Edizioni di Storia e Letteratura, 2003, pp. 286-291; 337-342; 439-451. 
seu uso pelos sacerdotes da Companhia. Mas é evidente que este poder constituía uma ameaça para a Inquisição, porque tendia a escapar ao seu controlo. No caso de João Nunes, um padre jesuíta que actuava como missionário em Tetuán (Marrocos), no início dos anos cinquenta, o problema foi superado graças à concessão duma idêntica faculdade pelo cardeal infante D. Henrique ${ }^{(24)}$. Mas é improvável que uma estratégia análoga tenha sido seguida pelo inquisidor geral no caso do padre Gonçalo Vaz de Melo que, entre 1551 e 1552, esteve em missão no Algarve, recorrendo, ao que parece, ao poder de absolver os hereges no foro da consciência ${ }^{(25)}$. Até que ponto os jesuítas usaram esta faculdade e em que medida os inquisidores foram informados disto e tentaram intervir, não se sabe. Contudo, ainda no final dos anos cinquenta do século XVII, o jesuíta Pedro Soares, que durante muitos anos tinha leccionado teologia moral no colégio de $\mathrm{S}$. Paulo de Braga, reivindicava a validade dos privilégios concedidos à Companhia pelo Papa Paulo III, sublinhando que, pelo menos para Portugal, nunca tinham sido anulados ${ }^{(26)}$.

(24) Ver a carta de António de Quadros ao padre geral Inácio de Loyola, Lisboa, 16 de Março de 1554, publicada em "MHSI", Litterae Quadrimestres ex universis praeter Indiam et Brasiliam locis in quibus aliqui de Societate Jesu versabantur Romae missae (daqui em frente abreviado em Litt. Quadr.), 7 vols., Madrid-Roma 1894-1932; vol. II, pp. 583-587. Uma cópia sem data da licença dada pelo cardeal infante D. Henrique ao padre João Nunes acha-se publicada em Isaías da Rosa Pereira, Documentos para a história da Inquisição (Século XVI), Lisboa, Cáritas Portuguesa, 1987, pp. 31-32.

(25) Chronica dos PP. Jezuitas de Portugal, em Biblioteca Pública Municipal do Porto, cod. 162 (764), pp. 445-446. Trata-se de uma crónica manuscrita anónima que deve ser datada do fim do século XVII e que relata a história da Companhia de Jesus em Portugal entre 1556 e 1570, continuando a narração do padre Baltasar Teles. Sobre o episódio ver também a carta de Frutuoso André ao padre geral Inácio de Loyola, Algarve, 22 de Julho de 1552, em "MHSI", Litt. Quadr., vol. 715-718, em particular p. 717. Mais em geral sobre as missões no Algarve do padre Gonçalo Vaz de Melo em 1551-1552, ver Francisco Rodrigues, ob. cit., t. I, vol. 1, pp. 673-676.

(26) Ver Pedro Soares, Tractatus de casibus in hoc Archiepiscopatu Braccharensi et in Episcopatibus suffraganeis reservatis, em Biblioteca Geral da Universidade de Coimbra, ms. 1040, fls. 126-127. 


\section{Os fundamentos da futura colaboração entre a Inquisição e a Companhia de Jesus}

Os anos cinquenta não foram, em todo o caso, um período de conflito entre inquisidores e jesuítas, mas antes a época em que se lançaram os fundamentos da futura colaboração entre ambas as partes. Neste período houve episódios e experiências que tiveram uma importância decisiva.

Em Agosto de 1550, a comunidade académica de Coimbra foi atingida pela prisão de três dos mais afamados professores do Colégio das Artes, recentemente fundado em 1547. OSanto Ofício culpou-os de serem hereges luteranos. Tratava-se dos portugueses Diogo de Teive e João da Costa e do escocês George Buchanan, todos provenientes do Collège de Guyenne de Bordeaux e discípulos de André de Gouveia. A notícia fez escândalo, mas a única voz que tomou a defesa dos professores bordoleses foi a do doutor Navarro, o canonista Martín de Azpilcueta, naquele tempo também docente universitário na cidade do Mondego. No dia 8 de Setembro, Navarro escreveu à rainha $D$. Catarina uma carta em que afirmava: "nunca oy yo que en una sola vez se prendiessen tres maestros lientes de una Universidad por ereies"(27).

Os processos inquisitoriais que se realizaram em Lisboa entre 1550 e 1551, magistralmente estudados por Mário Brandão, foram o ponto culminante de um ataque das hierarquias eclesiásticas, já posto em prática havia alguns anos, contra os expoentes dos ambientes mais animados e abertos às influências culturais e religiosas, de marca principalmente erasmiana, provenientes do estrangeiro ${ }^{(28)}$. Em Coimbra, onde os jesuítas

(27) Publicada em Mário Brandão, Alguns documentos respeitantes à Universidade de Coimbra na Época de D. João III, Coimbra, Biblioteca da Universidade, 1937, pp. 38-39.

(28) Ver o fundamental estudo de Mário Brandão, A Inquisição e os professores do Colégio das Artes, Coimbra, Universidade de Coimbra, 1948-1969, 2 vols. Os processos de Buchanan, Teive e Costa são publicados respectivamente em George Buchanan in the Lisbon Inquisition. The records of his trials, with a translation thereof into english, fac-similes of some of the papers and an introduction, by Guilherme J. C. Henriques, Lisboa, Typ. História de Portugal, 1906, pp. 21-40; Mário Brandão, O processo na Inquisição de Me. Diogo de Teive, Coimbra, Casa Tipográfica Alves \& Mourão, 1943; Idem, O processo na Inquisição de Mestre João da Costa, Coimbra, Arquivo e Museu de Arte da Universidade de Coimbra, 1944. 
iam adquirindo, gradualmente, cada vez mais importância, não tinham faltado disputas entre os padres da Companhia e os professores bordoleses ${ }^{(29)}$. Os jesuítas, na realidade, não desempenharam um papel directo e activo na acusação dos três mestres detidos mas, alguns deles, participaram nos processos como testemunhas, denunciando os erros dos réus ${ }^{(30)}$. Muito significativo foi o depoimento do padre provincial, mestre Simão Rodrigues, ouvido pelos inquisidores de Lisboa no dia 1 de Setembro de 1550, durante uma sessão do processo contra João da Costa ${ }^{(31)}$. A intervenção de mestreSimão integrava-se numa mais geral atitude hostil do jesuíta para com os mais inquietos representantes da vida religiosa portuguesa. Daí a poucos dias, em 24 de Setembro, Rodrigues voltou a ser chamado pelo Santo Ofício de Lisboa para ser reperguntado acerca de uma denúncia que tinha feito em Setembro de 1545 aos inquisidores de Évora contra o humanista Damião de Góis, o franciscano frei Roque

(29) Para uma apresentação global das tendências no ensino dos jesuítas em Portugal, cf. o clássico estudo de Francisco Rodrigues, A Formação Intellectual do Jesuita. Leis e Factos, Porto, Livraria Magalhães \& Moniz Editora, 1917. Sobre as tensões existentes em Coimbra entre o fim dos anos quarenta e o início dos cinquenta ver Mário Brandão, A Inquisição cit., vol. II, pp. 27-58.

(30) Ver ibidem, vol. II, pp. 87-107. Os jesuítas que testemunharam foram cinco: Luís de Grã, Diogo Gomes Teles, Diogo de Alarcão, Maurício Serpa e o padre provincial Simão Rodrigues. A presença de jesuítas, aos quais em 1555 foi entregue a direç̧ão do Colégio das Artes, desencadeou uma longa polémica entre os historiadores acerca das responsabilidades directas da Companhia na organização dos processos contra os professores bordoleses. As acusações, surgidas já em alguns libelos anti-jesuíticos da época pombalina, foram tomadas e relançadas por Teófilo Braga, História da Universidade de Coimbra nas suas relações com a instrução pública portugueza, 4 vols., Lisboa, por Ordem e na Typ. da Academia das Sciencias, 1892-1902; vol. II, p. 269. A revisão da tese da conspiração jesuíta começou por Guilherme J. C. Henriques, George Buchanan cit., pp. VIII-XI, seguido por Francisco Rodrigues, ob. cit., t. I, vol. 2, pp. 336-354. O debate é resumido em Mário Brandão, ob. cit., vol. II, pp. 4-9, o qual depois evidencia também a parcialidade de todas as precedentes interpretações, reconstruindo em detalhe o episódio da entrega do Colégio das Artes à Companhia e demonstrando que a principal responsabilidade no ataque aos professores bordoleses pertence ao grupo de teólogos formados na Sorbonne de Paris liderados por Diogo de Gouveia o Velho (ver ibidem, pp. 905-961).

(31) Ver Mário Brandão, O processo na Inquisição de Mestre João da Costa cit., pp. 44-45. 
de Almeida e o deão da Sé da Guarda, Lucas d'Orta, acusando-os de terem ideias luteranas. Neste caso não foram instruídos processos, mas mais uma vez o mestre Simão mostrava o seu alinhamento com posições do cardeal infante $\mathrm{D}$. Henrique e a sua propensão para o recurso à arma inquisitorial ${ }^{(32)}$.

Durante a celebração dos processos contra os professores do Colégio das Artes, acabados em Julho de 1551, chegou a Évora o dominicano frei Luís de Granada, a convite do cardeal D. Henrique. Granada juntou-se aos "sacerdotes recogidos" espanhóis, discípulos de Juan de Ávila, que actuavam na cidade alentejana, desde o fim dos anos quarenta, sob a direcção de Diego de Santa Cruz, o qual, em 1550, tinha entrado na Companhia de Jesus ${ }^{(33)}$. Este acontecimento, juntamente com a boa opinião sobre os jesuítas que tinha o influente dominicano Granada, persuadiu D. Henrique, que era arcebispo da cidade, a oferecer, em 1551, o Colégio do Espírito Santo à Companhia de Jesus, que fez assim a sua entrada oficial em Évora ${ }^{(34)}$. No mês de Outubro, os primeiros nove

(32) As denúncias de Simão Rodrigues, apresentadas aos inquisidores de Évora nos dias 5 e 7 de Setembro de 1545 e aos inquisidores de Lisboa no dia 24 de Setembro de 1550, encontram-se no fascículo que abre o processo contra Damião de Góis iniciado em Abril de 1571, publicado em Inéditos Goesianos. Fac-simile da edição de 1896-1898, por Guilherme J. C. Henriques, vol. II, O Processo na Inquisição, Arruda dos Vinhos, Arruda Editores, 2002. Sobre os depoimentos de Rodrigues contra Góis, cf. Francisco Rodrigues, História cit., t. I, vol. 2, pp. 23-29. Segundo a sua opinião, um pouco apologética "não só não se revela ódio nem rancor de nenhuma espécie, mas só se transparece o desejo de acertar e receio de exceder a verdade por pouco que fosse" (pp. 25-26); José Carlos Monteiro Pacheco, ob. cit., pp. 58-60. Mais em geral, sobre o processo de Góis, ver o estudo de José Pedro Paiva, "'Católico sou e não luterano': o processo de Damião de Góis na Inquisição (1571-1572)", em Damião de Góis. Um humanista na Torre do Tombo, por José Vicente Serrão, Lisboa, Instituto dos Arquivos Nacionais da Torre do Tombo, 2002, pp. 20-42.

(33) Sobre a chegada de Luís de Granada, ver Alvaro Huerga, Fray Luis de Granada. Una vida al servicio de la Iglesia, Madrid, Biblioteca de Autores Cristianos, 1988, pp. 96-100. Sobre o papel tido por Juan de Avila na chamada de Granada ver Luis Sala Balust, Obras Completas del B. Mtro. Juan de Avila. Edicion critica, 2 tomos, Madrid, La Editorial Catolica, 1970-1971; t. I, pp. 134-135. Referências ao colégio de "sacerdotes recogidos" acham-se ibidem, t. I, pp. 75-76; José Sebastião da Silva Dias, ob. cit., pp. 173-174; Idem, A política cultural da época de D. João III, Coimbra, Universidade de Coimbra, 1969, pp. 463-465.

(34) Ver Francisco Rodrigues, ob. cit., t. I, vol. 1, pp. 579-582. 
jesuítas chegaram à cidade e começaram com entusiasmo a actividade religiosa, sobretudo através da predicação, dos exercícios espirituais, da administração dos sacramentos (em particular a confissão) e das primeiras missões no interior ${ }^{(35)}$. Em breve D. Henrique reconheceu na Companhia de Jesus um importante aliado para o seu projecto de relance das instituições eclesiásticas e da vida religiosa do arcebispado e, mais em geral, do país. A experiência dos anos Cinquenta numa Évora atravessada por uma profunda renovação da vida cultural e religiosa e das correntes espirituais, graças também à presença de personagens como frei Luís de Granada, frei Bartolomeu dos Mártires ou Gaspar de Leão, a qual mereceu ao Alentejo desta época o epíteto de "un des foyers de la piété la plus christocentrique", dado por Marcel Bataillon, foi decisiva para o futuro da Companhia, tendo-lhe permitido ganhar a confiança e a simpatia do cardeal infante D. Henrique ${ }^{(36)}$.

O processo de legitimação da presença dos jesuítas em Portugal sofreu uma dramática interrupção por causa da grave crise que atingiu a Companhia a seguir à destituição do provincial Simão Rodrigues, determinada por Inácio de Loyola, no fim de 1551. Rodrigues tinha uma extraordinária popularidade em Portugal e gozava do pleno favor dos soberanos, mas o nivel de poder alcançado e a multiplicação de episódios de insubordinação e desobediência expuseram-no às críticas provenientes do estrangeiro, acabando por provocar a sua queda. A crise prolongou-se até 1553, tendo o governo da província passado ao espanhol Diego Mirón,

(35) Sobre as missões no interior dos jesuítas na arquidiocese de Évora ver Federico Palomo del Barrio, Fazer dos campos escolas excelentes. Os Jesuítas de Évora e as missões do interior em Portugal (1551-1630), Lisboa, Fundação Calouste Gulbenkian-Fundação para a Ciência e Tecnologia, 2003. Ver também, mais em geral, Marie-Lucie Copete-Federico Palomo del Barrio, "Des carêmes après le carême. Stratégies de conversions et functions politiques des missions intérieures en Espagne et au Portugal (1540-1650)", Revue de synthèse, 4e sér., vol. 120, 1999, pp. 359-380. Novos dados também em Federico Palomo del Barrio, "'Fazer arripiar as carnes e os cabelos'. Les cérémonies de la pénitence dans les missions des Jésuites au Portugal (1540-1650)", em Religious Cerimonials and Images: Power and social meaning (1400-1750), edited by José Pedro Paiva, Coimbra, E.S.F.-C.H.S.C.-Palimage Editores, 2002, pp. 155-176.

(36) Sobre as características da espiritualidade dos jesuítas em Portugal durante estes anos ver José Sebastião da Silva Dias, Correntes cit., pp. 169-175; 641-642. Para o juízo de Marcel Bataillon ver ob. cit., p. 224. 
enquanto a gestão imediata foi cometida a um visitador plenipotenciário, o doutor Miguel de Torres, que procedeu a uma verdadeira depuração, expulsando da Companhia os numerosos fiéis de mestre Simão ${ }^{(37)}$.

À terrível tempestade seguiu-se uma lenta, mas inexorável recuperação. O novo provincial Diego Mirón era um orgulhoso partidário do segregacionismo e já se tinha batido com veemência em Espanha para impedir o acesso de cristãos-novos à Companhia, suscitando as duras críticas de Juan de Ávila ${ }^{(38)}$. Em Portugal continuou a sua batalha, opondo-se à presença na Companhia de um jovem de origem judaica, destinado a tornar-se um dos mais famosos teólogos jesuítas lusitanos, Henrique Henriques, irmão de Manuel Lopes. Henriques tinha sido recebido na India, por Francisco Xavier, na segunda metade dos anos quarenta. $O$ seu caso, que apresentava também a agravante de ele ter vestido o hábito franciscano antes de entrar na Companhia, tinha sido debatido muito tempo até à intervenção de Inácio no início de 1552, quando o fundador da Companhia se exprimiu definitivamente a favor de Henriques ${ }^{(39)}$. Mas entre o fim de 1553 e o início de 1554 a questão chegou a ser discutida também em Portugal e Mirón pronunciou-se contra o jesuíta cristão-novo, alegando também a questão do hábito ${ }^{(40)}$. Inácio

(37) Para uma ampla descrição da crise da província portuguesa entre 1551 e 1553 ver Francisco Rodrigues, ob. cit., t. I, vol. 2, pp. 91-237. Para uma rápida síntese ver Ricardo García Villoslada, ob. cit., pp. 731-743; José Carlos Monteiro Pacheco, ob. cit., pp. 141-183; John W. O'Malley, ob. cit., pp. 364-367.

(38) Cf. Luis Sala Balust, ob. cit., t. I, pp. 163-165.

(39) Para a posição de Mirón enquanto provincial de Portugal acerca dos cristãos-novos ver Francisco Rodrigues, ob. cit., t. I, vol. 1, pp. 487-488; José Sebastião da Silva Dias, ob. cit., p. 175. Sobre o caso de Henrique Henriques ver Isräel-Salvator Révah, "Les origines" cit., pp. 89-90; Francisco de Borja Medina, ob. cit., pp. 589-592. Mais em geral, em relação à presença de cristãos-novos na Companhia em Índia ver Josef Wicki, "Die 'Cristãos-novos' in der indischen Provinz der Gesellschaft Jesu von Ignatius bis Aquaviva", Archivum Historicum Societatis Iesu, vol. XLVI, 1977, pp. 342-361.

(40) Ver a carta de Inácio de Azevedo por comissão do padre provincial Diego Mirón ao padre geral Inácio de Loyola, Lisboa, 7 de Dezembro de 1553: "En la India ai un Padre en la Compañia que se llama Enrrique Enrriquez. Es mui virtuoso y haze mucho fruto en los christianos del Cabo de Comorín, los quales le tienen mucha reverencia. Este fue novitio y no sé por quánto tiempo en los frailes descalços de S. Francisco; este es impedimento essential para uno no ser de la Compañia. Mire V. Paternidad lo que se a de hazer en ello y mándenos dar 
interveio novamente com uma carta, datada a 5 de Abril de 1554. A sua resposta interessa-nos sobretudo em relação ao problema da linhagem. $\mathrm{Na}$ carta, enviada a Mirón, insistia na proibição de qualquer forma de discriminação, mas admitia a existência do problema e aconselhava a agir com cautela:

"Acerca del P. Enrrique Enrricquez, las dos cosas que scrive dél V. R. se sabían acá; y no obstante ellas, N. P. dispensó con él, para que stubiese en la Compañia, antes que las Constituciones se publicasen. $Y$ advierta $V$. R. que el ser de linaje de christianos nuevos no es empedimiento que escluya de la Compañia, aunque haze abrir los ojos más para el rescivir los tales con pruevas sufficientes, por lo que se suele muchas vezes hallarse en semejantes hombres, que es ser difficiles; y desto en fuera, en la Compañia non est distinctio judaei et graeci etc., quando son unidos en el mesmo spíritu del divino servicio con los otros. $Y$ advierta V. R. que es notado de mirar mucho en esto, ó por mejor dezir, de trattar dello algo más que convendría al descubierto, lo qual sería para desconsolar y aun tentar no ligeramente algún bueno supósito, á quienes toca algo desto. Es verdad que, si por la dispositión de los ánimos de una tierra, no fuese cosa edificativa aceptar alguno tal, diestramente se podria enderezar á otra parte, si fuese buen supósito"(41).

De qualquer maneira, o episódio mostrava a persistência da presença duma firme oposição aos cristãos-novos na direcção da Companhia em Portugal. Outros factos contribuíram para o crédito acordado pelo cardeal à Companhia naquele momento. Por exemplo, confirmações ulteriores da possível colaboração, entre os inquisidores lusitanos e os jesuítas provinham da Península Italiana, um dos destinos predilectos dos cristãos-novos que fugiam de Portugal. Ainda no mesmo dia 5 de Abril de 1554, foi enviada de Roma uma outra carta ao padre Mirón, em que se dava notícia que:

aviso, y ultra es christiano nuevo" (em "MHSI", Monumenta Brasiliae, 5 vols., Roma, 1956-68; vol. V, pp. 14-22, em particular p. 21).

(41) Carta escrita por comissão do padre geral Inácio de Loyola ao padre provincial Diego Mirón, Roma, 5 de Abril de 1554, publicada em "MHSI", MI Epp, vol. VI, pp. 567-570, em particular pp. 569-570. 
"uno de los nuestros, que se llama Mtro. Bobadilla, fué ymbiado á la Marca de Ancona, parte por visitar el clero de nuestra Señora de Loreto, parte por comisario de la inquisitión en aquellas partes. Después de haver quemado los Talmudes de los judíos y otros libros heréticos, quemó también este libro portugués, que para hazer daño era tanto al propósito, y más por ventura que el Talmud. Escreviósele de parte de N. P. que guardase un volumen para que allá ymbiásemos al señor infante cardenal, y así va con esta. V. R. la dé ó la ymbie á S. A."(42).

Segundo nos informam outras fontes, a queima de Talmudes e de outros livros judaicos escritos em língua portuguesa teve lugar em praça pública em Ancona no dia 1 de Fevereiro de $1554^{(43)}$. O episódio assume uma importância ainda maior se se toma em consideração que havia fama que o jesuíta Nicolás Bobadilla tivesse origem cristã-nova ${ }^{(44)}$.

A comunidade dos marranos portugueses de Ancona foi sempre objecto de uma cuidadosa descrição. Numa alarmante denúncia feita pelo antigo provincial lusitano, mestre Simão Rodrigues, em carta que

(42) Carta escrita por comissão do padre geral Inácio de Loyola ao padre provincial Diego Mirón, Roma, 5 de Abril 1554, publicada em "MHSI", MI Epp., vol. VI, p. 567.

(43) Ver Brevissima historiae vitae R. P. Mtri. Nicolai de Bobadilla, unius ex decem patribus Societatis Iesu, breviter incipit, publicada em "MHSI", Nicolai Alphonsi de Bobadilla sacerdotis e Societate Jesu Gesta et Scripta, Madrid, 1913, pp. 613-633; em particular pp.625-626; a carta escrita por comissão do padre geral Inácio de Loyola ao padre Nicolás de Bobadilla, Roma, 10 de Fevereiro de 1554, em "MHSI", MI Epp, vol. VI, pp. 307-308; a carta escrita por comissão do padre geral Inácio de Loyola ao padre Nicolás de Bobadilla, Roma, 10 ou 11 de Fevereiro de 1554, ibidem, p. 318; Chron., vol. IV, pp. 141-142. Sobre o episódio ver também John W. O'Malley, ob. cit., p. 346. "O livro português de que se fala era, sem dúvida, o Consolaçom as Tribulaçoens de Ysrael de Samuel Usque, publicada em Ferrara em 1553. Ver Samuel Usque, Consolação às Tribulações de Israel. Edição de Ferrara, 1553, com estudos introdutórios por Yosef Hayim Yerushalmi e José Vitorino de Pina Martins, Lisboa, Fundação Calouste Gulbenkian - Centro Cultural Português, 1989, 2 vols.

(44) Ver a carta do padre Antonio de Araoz ao padre geral Inácio de Loyola, Madrid, 14 de Janeiro de 1552: “Uno me dixo que sabía de çierto que Mtre. Bobadilla era hijo de un tornadizo, id est que por sus pyes fue a la pila, uu aiunt" (publicada em "MHSI", Epistolae mixtae ex variis Europae locis ab anno 1537 ad 1556 scriptae (daqui em frente abreviado em Epp. Mixtae), 5 vols., Madrid, 1898-1901 ; vol. II, p. 656). 
escreveu ao rei D. João III, no dia 10 de Julho de 1554, de Veneza, refere-se que cumpria as funções de informador do soberano e, indirectamente, da Inquisição sobre a vida e as opiniões dos marranos de Ancona. $\mathrm{Na}$ segunda parte convertia-se em conselheiro sugerindo ao rei uma estratégia determinada para obter a repatriação dos cristãos-novos portugueses presentes em Ancona, Ferrara e outras partes de Itália:

"Vossa Alteza he rei inclinado a piedade e misericordia, veja se convem perdoar a esta gente e dar-lhes licença para se tornar com perdão do Papa e por alguns particulares, se os ahi ouver, os quaes se podem exceituar, nam percam todos, he sera necessario huma pessoa que entenda neste negocio avendo-o Vossa Alteza por serviço de Deus e seu e que esforcem alguns fracos e vá a Ferrara honde tambem ha grão moltidão delles e outras partes donde elles estão e proceda destramente para que este serviço de Deus não se perca pollo máo modo que nisso se pode ter. A qual pessoa seguirá a ordem que nisso Vossa Alteza quiser que se tenha secreta ou publica e certo que em caso de tão extrema necessidade esperitual parece obrigação e tanto mais quanto menos elles por outra via parece não ter outro remedio"(45).

A oposição do provincial Mirón à admissão de cristãos-novos na Companhia, a acção repressora de Bobadilla contra os livros dos marranos portugueses em Ancona e o esforço do antigo provincial Rodrigues para pôr um freio ao escândalo das fugas dos cristãos-novos para Itália, eram sinais claros de uma cada vez maior convergência das atitudes da Inquisição e de uma parte dos jesuítas portugueses.

Foi neste clima que surgiu a proposta de oferecer a um jesuíta um lugar de inquisidor, vago no Tribunal de Lisboa ${ }^{(46)}$. Em Abril de 1555 o rei comunicou este propósito ao provincial Mirón, o qual logo escreveu um longa e pormenorizada carta cheia de entusiasmo ao padre Francisco de Borja. Depois de ter descrito o funcionamento da Inquisição em Portugal e de ter apresentado as suas propostas para uma eventual reorganização

(45) Publicada em As Gavetas da Torre do Tombo, 13 vols., Lisboa, Centro de Estudos Históricos Ultramarinos, 1960-1977, vol. I, pp. 655-658, em particular p. 657.

(46) Sobre o episódio ver Francisco Rodrigues, ob. cit., t. I, vol. 1, pp. 693-696; José Luis González Novalin, ob. cit., pp. 23-27; António Lopes, ob. cit., pp. 660-663; John W. O'Malley, ob. cit., p. 343. 
jesuíta do Santo Ofício, Mirón declarava-se à espera do parecer de Roma, mas já anticipava as possíveis objecções:

"Los inconvenientes que acá se apunctaron para no tomar este assumpto, uno era $1 .^{\circ}$ En que nos haríamos muy odiosos, y que nos ternían miedo, por la authoridad que trae consigo el santo officio, y castigos, que no pareçe quadrar tanto con nuestra humilde manera de proçeder. 2. ${ }^{\circ}$ Temor que estos christianos nuevos se aprovecharían poco de nosotros con el miedo que nos ternán. $3 .^{\circ}$ Que reçelarían nuestras confessiones, pensando que les accusaremos, o que nos levante alguno que le descubrieron la confessión, quando le prendiessen por otra vía".

O provincial replicava, declarando que o cargo inquisitorial não interessaria à Companhia, mas apenas a um ou dois padres (ele pensava, em particular, no padre Marcos Jorge, "que lee los casos en Évora, y es buen canonista"). Ainda mais, Mirón mostrava o exemplo da Ordem de S. Domingos, cujos frades já tinham militado na Inquisição em Portugal sem escandalizar o povo, pelo contrário aumentando a sua autoridade. Por fim, continuava o jesuíta, "este género de gente de christianos nuevos es muy odiosa, y el castigo dellos es muy bien acçeptado en el mundo, y con grande applauso: lo qual nos haraa más benévolos y seguros para el mundo, y darnos crédito, assy en la vida como en la doctrina, y seremos mucho mejor reçebidos con semejante authoridad y crédito que tienen de nosotros. Yá lo demás, muy malos serán los que nos levantaren falso testimonio, y essos ni aun ahora nos vernán á las manos, y aun si tal fuesse, por los mismos testimonios se vería su falsedad: y en fin sería cosa muy rara, ó que nunca aconteçeraa"(47).

Em Roma acolheu-se a notícia com moderação. A luta contra a heresia era um dos principais terrenos de acção dos jesuítas, mas não através da arma inquisitorial. Além disso, conhecia-se muito bem a regra funda-

(47) Carta do padre provincial Diego Mirón ao padre geral Inácio de Loyola, Lisboa, 20 de Abril de 1555, publicada em Epp. Mixtae, vol. VI, pp. 646-651. A carta revela um profundo conhecimento do funcionamento do tribunal da Inquisição por parte do provincial da Companhia, o qual, pelo contrário, Francisco Rodrigues não hesitou em qualificar, mesmo em relação à carta citada, como homem de "simplicidade" (ob. cit., t. I, vol. 1, p. 693) e de "simpleza" (ibidem, p. 695), procurando diminuir a concreta importância do seu apoio à proposta do rei. 
mental da Companhia segundo a qual o ministério espiritual dos jesuítas seria tanto mais eficaz quanto menos se envolvessem nos poderes temporais. De qualquer maneira, na segunda metade de Junho, Inácio nomeou uma comissão de seis jesuítas que, à excepção de Laínez, votou a favor da proposta (os outros cinco eram Polanco, Bobadilla, Salmerón, Cristóforo de Madrid e Martín de Olabe). Mas quando o parecer favorável chegou a Lisboa, o cardeal infante já tinha mudado de ideias, talvez sob pressão dos dominicanos, e tinha nomeado o experimentado frei Jerónimo de Azambuja, que ocupava cargos inquisitoriais já desde $1549^{(48)}$. Aliás, ficavam ainda motivos de dúvida sobre a autoridade da Companhia em Portugal, que talvez fossem a causa de ter negado, por uma segunda vez, aos jesuítas tarefas na Inquisição ${ }^{(49)}$. Como escrevia Mirón a Inácio, numa carta de 5 de Setembro de 1555, D. Henrique queria reabrir o Tribunal do Santo Ofício de Coimbra e pensava entregá-lo à Companhia de Jesus, cuja presença na cidade do Mondego se tornava cada vez maior e à qual, mesmo naqueles dias, foi entregue a gestão do Colégio das Artes ${ }^{(50)}$. Podia ser a peça definitiva da progressiva hegemonia que os jesuítas estavam a ganhar nas instituições académicas de Coimbra. Mas esta segunda tentativa também, misteriosamente para nós que não temos outra documentação, se malogrou.

(48) A carta de resposta favorável de Inácio de Loyola, enviada ao padre provincial Diego Mirón de Roma, no dia de 20 de Junho de 1555, pode ver-se em "MHSI", MI Epp, vol. IX, pp. 226-227. A carta é editada também em Cartas de San Ignacio de Loyola fundador de la Compañia de Jesús, $\mathrm{t}$. V, Madrid, Imprenta de Don Luis Aguado, 1889, pp. 255-259, onde, todavia, a datação referida é do dia 20 de Julho. Além disso, ver Memoriale seu Diarium Patris Ludovici Gonzalez de Camara, publicado em "MHSI", Fontes narrativi de S. Ignatio de Loyola et de Societatis Jesu initiis, 4 vols., Roma, 1943-1965; vol. I, pp. 728; 732. Sobre as possíveis pressões dos dominicanos, ver José Luis González Novalin, ob. cit., p. 26, nota 57.

(49) Sobre a proposta de conceder aos jesuítas o Tribunal de Coimbra, que se intentava restabelecer, e sobre o não cumprimento deste segundo projecto, cf. Francisco Rodrigues, ob. cit., t. I, vol. 1, pp. 696-697. O autor comenta assim o êxito do episódio: "O resultado final foi o que melhor convinha à Companhia de Jesus" (p. 697).

(50) Ver a carta do padre provincial ao padre geral Inácio de Loyola, Lisboa, 5 de Setembro de 1555: "La carta del asumpto de la inquisitión de V. P. [scil. a do dia 20 de Junho de 1555] recebí, y la mostré luego á la reyna y infante. Dixéronme que aquello era de Dios, porque después de estar estorvado por el cardenal 
Nos anos seguintes as relações entre a Inquisição e a Companhia limitaram-se quase exclusivamente à assistência espiritual aos condenados à morte pelo Santo Ofício, actividade que os padres jesuítas começaram a praticar desde o auto-da-fé de Évora de 1553. Em Lisboa, os jesuítas foram chamados a ocupar-se dos condenados pela primeira vez na ocasião do auto-da-fé celebrado durante a Quaresma de 1555 e continuaram nos anos seguintes ${ }^{(51)}$. Tratava-se de uma obra de caridade muito delicada e difícil, como, por exemplo, se deduz pela descrição do zelo dos padres durante o auto-da-fé de Lisboa, de Setembro de 1559:

"En Setiembro se hizo aqui un acto de la santa inquisicion en que los del sancto officio ocuparon los nuestros (como hazen cada año) para estar con los que avian de padeçer, creo que los ayudaron bien en lo que les convenia para la salvacion de sus animas. Dos dias con sus noches estuvieron con ellos que fue del viernes hasta el domingo, y alla comian

nosotros tomar la inquisitión de Lixbona, después el mesmo cardenal escrevió de suyo al infante que falasse con el rey para que tomássemos la de Coímbra; de maneira que como hasta gora no vuo sino dos inquisitiones en Portugal, scil., Lisbona y Evora, que agora se dividiessen en tres y nosotros tuviéssemos la de Coímbra. El infante me dixo que el rey le respondió que era mui contento y assí lo escrevió al cardenal. Y estando esto assí sin yo saber nada, viendo esta carta el infante y reyna, alabaron á Dios y asentaron que seria más para su servicio, viendo cómo Diós de todas partes en un mesmo tiempo assí lo concertó. Díxome la reyna que mostraría la carta á el rey. Esto fué ayer; de lo que sucediere escreviré á V. P. largo" (publicada em "MHSI", MI Epp, vol. XII, pp. 511-514; em particular p. 513). Ver também Chron., vol. V, p. 604.

(51) Sobre a assistência aos condenados pela Inquisição durante os anos Cinquenta ver Francisco Rodrigues, ob. cit., t. I, vol. 1, pp. 691-693, o qual afirma que os jesuítas não "exerceram na Inquisição outros emprêgos durante o tempo de que ora nos ocupamos, senão isso da pura misericórdia com os padecentes" (p. 693). Sobre o auto-da-fé de Lisboa em 1555 ver Chron., vol. V, pp. 571-572, onde se dão também notícias acerca dos condenados assistidos. Por exemplo, sobre o francês Guilherme Bro (cujo precioso processo foi estudado e publicado por Isaías da Rosa Pereira, “Um Francês do Languedoque na Inquisição de Lisboa: Guilherme Bro, Clérigo de Missa (1553-1555)", em Actas das III Jornadas Arqueológicas, Lisboa, Associação dos Arqueólogos Portugueses, 1978, vol. I, pp. 423-251) diz o padre Polanco: "Alius, natione gallus, qui Burdigalae diu Lutheri haereses docuerat, et in regnis Hispaniae sacramenta ministraverat et convictus tandem fuerat, quamvis et ipse obstinatus aliquamdiu fuisset, placuit Deo eius animum emollire, et ut decebat bonum et catholicum christianum mortuus est". 
y dormian, ò para mejor dizir, ni comian, ni dormian por que la mayor parte de las noches gastavan con los condenados y para lo que quedava avia tan mal aparejo que casi todo el tiempo vigiavan. Las camas eran el suelo con una steria llena de pulgas, y chinchas, y los dias deayuno. $\mathrm{Al}$ domingo muj de mañana los acompañaron hasta el cadahalso onde estuvieron hasta la noche que duro el acto; antes que los quemassen los absolvieron, y parece que murieron buenos cristianos: fueron cinco los que justiciaron, à fuera otros que pidieron misericordia, todos estos por judaizar"(52).

A par com a actividade de assistência aos condenados, os jesuítas cumpriam também outras tarefas na Inquisição, sempre respeitantes a esferas espirituais, como a catequização dos penitenciados e a administração dos sacramentos aos presos. Por exemplo, numa carta quadrimestral do colégio de Évora, datada a 12 de Setembro de 1560, refere-se:

"Tambien se hazen las doctrinas a los penitenciados de la inquisition aqui en una classe de nuestro collegio, y con mucho gusto y provecho de los oientes, como se supo de uno de los inquisidores que de ello estan bien satisfechos.

Los dias passados tuvimos el jubileo que el papa Pio 4 dio por causa del consilio [...] y se occuparon los padres de casa en oyr confessiones las quales por esta causa fueron muchas. A la Inquisition fueron algunos de los Doctores y maestros que leen con otros padres, y confessaron en la primera semana todos los que lo avian de ganar"(53).

Não faltaram, contudo, episódios de cooperação directa nas operações de polícia com as autoridades encarregadas da vigilância da ortodoxia. Em 1556, o jesuíta Leão Henriques, um dos chefes da corrente segregacionista, reitor do Colégio de Coimbra, contribuiu de modo decisivo para

(52) Carta da Casa Professa de S. Roque, Lisboa, 17 de Fevereiro de 1560, publicada em "MHSI", Litt. Quadr., vol. VI, pp. 522-523.

(53) Carta do Colégio do Espírito Santo, Évora, 12 de Setembro de 1560, publicada ibidem, p. 841 ss. Em Agosto de 1552, simultaneamente ao primeiro regimento da Inquisição portuguesa, tinha sido promulgado também o Regimento da pessoa que tever carguo do collegio da doutrina da fee, publicado em António Baião, A Inquisição em Portugal e no Brasil. Subsidios para a sua História, Lisboa, Edição do Arquivo Histórico Português, 1920, doc. XXXV. 
a captura dum herege pelo bispo de Coimbra, João Soares, que actuava como inquisidor ordinário da diocese. Segundo o que narra Polanco:

"O zelo e a diligência do reitor padre Leão Henriques permitiram a captura dum herege, o qual tinha chegado a Coimbra para semear a cisânia. Ele tinha vindo à nossa casa e tinha falado com o sobredito reitor, o qual, tendo ele cometido não sei que, fez sair alguns dos nossos, que o padre Luís [scil. Gonçalves da Câmara] tinha reconduzido consigo em Portugal, sob aparências de romeiros para que, dissimulando, falassem com aquele homem; e naquele primeiro encontro, ele começou a espalhar o seu veneno, e assim o bispo, admoestado pelo padre Leão, deitou-o à cadeia"(54).

\section{Os irmãos Câmara e o apogeu da corrente rigorista}

No Outono de 1555, o padre Torres substituiu o provincial Mirón e, poucos meses depois, chegou a Portugal o padre Luís Gonçalves da Câmara, o qual tinha sido, durante vários anos, secretário pessoal de Inácio de Loyola. Duro adversário de mestre Simão, Luís Gonçalves da Câmara tornou-se rapidamente o chefe da corrente rigorista, que juntava os que contrariavam seja os indulgentes, discriminados pela antiga amizade com mestre Simão Rodrigues, os quais eram chefiados pelo padre Manuel Rodrigues, seja os cristãos-novos, que contavam no interior da Companhia com altas personalidade como o padre espanhol Cipriano Suarez. Os rigoristas, entre os quais sobressaíam os padres Leão Henriques,

(54) "Ejusdem [scil. P. Leonis Henriquez Rectoris] industria ac diligentia haereticus quidam, qui ad zizzaniam seminandam Conimbricam venerat, fuit comprehensus. Venerat ille domum nostram, et praedictum Rectorem fuerat allocutus, qui, nescio quid offecisset, emisit in habitu peregrinorum quosdam ex nostris, quos secum in Portugalliam P. Ludovicus reduxerat, qui hominum illum dissimulanter alloquerentur; et in primo illo congressu coepit ille suum venenum depromere, et ita Episcopus a P. Leone admonitus, in carcerem illum conjecit" (em "MHSI", Chron., vol. VI, p. 717. A tradução em português é minha). Sobre a repressão da heresia na diocese de Coimbra durante os anos de suspensão da actividade do tribunal do Santo Ofício, cf. Elvira Cunha de Azevedo Mea, A Inquisição de Coimbra no Século XVI. A Instituição, os Homens e a Sociedade, Porto, Fundação Eng..$^{\circ}$ António de Almeida, 1997, pp. 81-96. 
primo de Gonçalves da Câmara, Maurício Serpa, Inácio Martins e Jorge Serrão, conseguiram impor o seu domínio durante quase a totalidade das duas décadas seguintes ${ }^{(55)}$.

O reforço da Companhia deveu-se igualmente à estreita aliança entre os rigoristas e o cardeal infante D. Henrique, o qual, depois da morte do rei D. João III, em 1557, por causa da menoridade de D. Sebastião, assumiu cada vez mais poderes políticos, até obter, em 1562, a regência, sucedendo a D. Catarina ${ }^{(56)}$. A nova aliança com os jesuítas foi sancionada, em 1559, pela abertura da Universidade de Évora, cuja direcção foi entregue à Companhia e, sobretudo, sempre no mesmo ano, pela escolha de Luís Gonçalves da Câmara como futuro preceptor de D. Sebastião. O cardeal conseguiu impor o seu candidato em vez do dominicano Luís de Granada e do agostiniano Luís de Montoia, ambos espanhóis, apoiados por D. Catarina ${ }^{(57)}$. O início dos anos sessenta distinguiu-se pela consolidação da Companhia, a qual, entre 1560 e 1561, abriu novos colégios no Porto, em Braga e em Bragança ${ }^{(58)}$. Também a Inquisição gozou do extraordinário poder alcançado pelo cardeal infante e obteve novas faculdades $e$ privilégios. Conseguiu até fundar um novo tribunal em Goa, após áspero debate, ocorrido desde meados dos anos quarenta até aos anos cinquenta, que teve nos missionários jesuítas partidários fervorosos da criação da Inquisição na Índia ${ }^{(59)}$.

(55) Sobre as divisões na Companhia em Portugal entre duas correntes, uma do "rigor" e outra da "brandura", ver Francisco Rodrigues, ob. cit., t. II, vol. 1, pp. 293-329.

(56) Sobre estes anos da vida política portuguesa ver Maria do Rosário de Sampaio Themudo Barata de Azevedo Cruz, As regências na menoridade de D. Sebastião. Elementos para huma história estrutural, Lisboa, Imprensa Nacional-Casa da Moeda, 1992, 2 vols.

(57) Sobre o conflito entre D. Henrique e D. Catarina pela escolha do mestre do rei D. Sebastião ver ibidem, vol. I, pp. 96-99. Sobre a obra educativa de Gonçalves da Câmara ver Francisco de Sales de Mascarenhas Loureiro, "O Padre Luís Gonçalves da Câmara e D. Sebastião", separata de O Instituto, vol. CXXXVI, 1973.

(58) Ver Francisco Rodrigues, ob. cit., t. I, vol. 2, pp. 401-432.

(59) Sobre o debate para a instituição do tribunal do Santo Ofício de Goa e sobre o papel desempenhado pelos jesuítas ver Ana Isabel Canas da Cunha, A Inquisição no Estado da India. Origens (1539-1560), Lisboa, Arquivos Nacionais Torre do Tombo, 1995, pp. 125-146. 
Outro episódio importante para a história das relações entre a Companhia e a Inquisição foi a questão da introdução no reino do índice universal dos livros proibidos do Papa Paulo IV, o único preparado pelo Santo Ofício romano. Portugal foi o único país fora da Itália onde se publicou o índice paulino, que foi editado em Coimbra, por iniciativa do bispo João Soares, no início de 1559. Esta edição foi realizada a partir da primeira e mais dura versão do índice paulino, a publicada em Roma por António Blado, no fim de Dezembro de 1558, que foi parcialmente moderada, no ano seguinte, pela Instructio circa Indicem ${ }^{(6)}$. As condenações categóricas e inauditas contidas no índice de Paulo IV suscitaram fortes polémicas, também entre os jesuítas, que temiam não poder continuar a usar muitos dos textos a que recorriam para as aulas nos seus colégios. Depois de alguns protestos, no dia 30 de Janeiro de 1559, o geral da Companhia, Diego Laínez, obteve do inquisidor mor do Santo Ofício Romano, o dominicano frei Michele Ghislieri, um privilégio pelo qual se concedia aos jesuítas a faculdade de ter e usar nos colégios alguns livros que eles já possuíam, contanto que os corrigissem ${ }^{(61)}$. Tratava-se duma licença extraordinária e sobre a qual se devia manter segredo. Não foi isso, todavia, o que sucedeu em Portugal, onde, ao contrário, foi dado grande realce à notícia, que foi interpretada como uma prova da confiança das hierarquias eclesiásticas romanas na Companhia. Além disso, esta prerrogativa marcava o ingresso dos jesuítas portugueses no mundo da censura dos livros, onde, como veremos, muito actuariam nos anos sucessivos. O relato dos jesuítas sobre a publicação do índice em Coimbra mostra claramente o entusiasmo dos padres para com o novo poder:

"Los dias pasados se publico en esta ciudad el breve de Su Santidad iuntamente con el catalogo de los libros prohibidos y en este mismo tiempo nos mando el padre provincial de Lisboa la facultad que Su Sanctidad conçedio a la Compañia y a los discipulos della para retener algunos de los libros prohibidos despues de vistos y en medados fue

(60) Sobre a edição portuguesa do índice paulino ver Index des Livres Interdits, vol. IV, Index de l'Inquisition Portugaise. 1547, 1551, 1564, 1581, par Jesús Martinez de Bujanda, Sherbrooke-Genève, Centre d'Études de la Renaissance-Droz, 1995, pp. 54-55.

(61) Ver John W. O'Malley, ob. cit., pp. 345-346. 
esta una cosa que despues de poblicada dio gran edificacion a los de fuera con ver el mucho credito que Su Sanctidad mostrava tener a los de la Compañia y muchos aun doctores deseavan ser nuestros discipulos oyendo hebraico. Ordeno el padre doctor Miron que un padre de casa tomase cargo con algunos que lo ayudavan de ver los libros de nuestros studiantes y cortar y enmendar todo lo que era necessario para se los daren enmendados y fue grande la copia de los libros que con este privilegio se les aprovecharon de que ellos tambien estan muy contentes $\mathrm{y}$ tomaron los estudiantes esto con tanta devocion y tanto de verdad que los demas dellos no solamente trayan los libros donde avia alguna duda mas aun los que era muy cierto no seren prohibidos no querian usar dellos sin primero seren aprovados y vistos por la Compañia"(62).

Pelo contrário, o facto de as duras condenações do índice espanhol, publicado pelo inquisidor geral Fernando de Valdés, poucos meses depois, não terem sido acolhidas em Portugal, é sinal evidente da posição diferente com que se olhava para as formas mais interiores de espiritualidade. Em Espanha proibiam-se obras de Juan de Ávila, Luís de Granada e do padre Francisco de Borja. A Companhia sentia-se sob acusação. Em Portugal, ao invés, o clima ficou sossegado, graças à protecção que o cardeal garantia a Granada e aos jesuítas, a tal ponto que o mesmo Borja passou a fronteira, onde achou abrigo ${ }^{(63)}$.

(62) Carta do padre Pedro Dias por comissão do padre Diego Mirón, Coimbra, 30 de Abril de 1559, em "MHSI", Litt. Quadr., vol. VI, p. 131 ss. Não é claro se o breve a que se refere a carta seja o Cum nihil atque, concedido pelo papa Paulo IV ao inquisidor geral de Espanha Fernando de Valdés, Roma, 5 de Janeiro de 1559. Este breve mandava aos confessores que interrogassem os penitentes sobre a posse e a leitura de livros proibidos e que se informassem também sobre os culpados conhecidos pelos penitentes. Em caso de suspeitas, os confessores deviam denegar a absolvição e enviar o penitente à Inquisição. Sobre este breve de importância fundamental para as relações entre confissão sacramental e Inquisição ver Adriano Prosperi, Tribunali della coscienza. Inquisitori, confessori, missionari, Torino, Giulio Einaudi Editore, 1996, pp. 230-232. Para Espanha ver Stefania Pastore, Il Vangelo cit., pp. 249-253.

(63) Sobre a passagem do padre Francisco de Borja a Portugal ver Cándido de Dalmases, "San Francisco de Borja y la Inquisición Española", Archivum Historicum Societatis Iesu, vol. XLI, 1972, pp. 48-135. Sobre a influência de D. Henrique sobre as tendências censórias em Portugal, ver as observações de Jesús Martinez de Bujanda em Index cit., pp. 117-118. 
Depois do fim do concílio de Trento, em 1563, a Companhia de Jesus representou uma das instituições mais activas na obra de evangelização e de relance da Igreja católica. Em Portugal, graças também à forte ligação com o poder político e com muitos bispos, os jesuítas foram dos maiores protagonistas da vida religiosa e cultural da Contra-Reforma. Ensinavam nos colégios e nas universidades, colaboravam na formação do clero através das aulas de casos de consciência, organizavam missões no interior, atingindo povoações distinguidas por um nível de cristianização muito escasso, as chamadas "Índias" de Portugal, pregavam, administravam os sacramentos ${ }^{(64)}$. Os seus colégios e casas atraíam os fiéis que encontravam nos jesuítas os mais preparados directores espirituais, sobretudo nestes anos de ardente propaganda a favor da confissão frequente.

Durante os anos sessenta alguns padres da Companhia continuaram a dar provas de fidelidade ao cardeal e à Inquisição, prosseguindo as actividades de catequização dos penitenciados pelo Santo Ofício, como se lê numa carta escrita por António Pacheco, em Setembro de 1564: "Despues del acto de la inquisission, de que abaxo hablare, van los Nuestros a petiçion del Serenissimo cardenal Inquisidor Mayor dos vezes en la semana, a instruir los penitenciados, de que con palabras de mucha satisfacion se muestran muy satisfechos assi el Cardenal como los los Señores Inquisidores". Aos padres da Companhia os inquisidores costumavam também enviar algumas pessoas para que com conselhos e admoestações os ajudassem a recuperar as almas deles, como mostra a mesma missiva de António Pacheco:

“Vinieron a esta Casa [scil. de S. Roque] 4 hombres los quale inspirados por Diós se venian a acusar a los Inquisidores de sus errores y ceguedades, fueron absueltos de los Señores Inquisidores con condiçion que viniessen a esta Casa algunos dias a se instruir en las cosas de la fee de lo que se sirvio mucho Dios Nuestro Señor. Otro tambien vino aqui, al qual avia aconteçido un grave caso, y tambien se venia a acusar, embiaron lo tambien aca los Inquisidores, para que lo informassen como al primero y

(64) Sobre a actividade dos missionários jesuítas nas áreas extra-urbanas dos países católicos europeus ver Adriano Prosperi, "'Otras Indias'. Missionari della Controriforma tra contadini e selvaggi", em Scienze, Credenza Occulte, Livelli di cultura. Convegno internazionale, Firenze, Olschki, 1982, pp. 205-234; Idem, Tribunali cit., pp. 551-684. 
esto hecho fue el padre a darles informaçion del dicho hombre, y pedirles lo despachassen con lo qual los Inquisidores se consolaron mucho dando muchos agradescimientos por las buenas obras y aiuda spiritual que desta casa se les dava, en esta y la demas que ïa dixe"(65).

O problema dos cristãos-novos, no entanto, mantinha-se em aberto. Uma carta escrita por Diego Mirón ao geral Laínez, no dia 12 de Novembro de 1564, afrontava a questão e revelava as razões sociais contidas nas pressões dos cristãos-novos para serem admitidos na Companhia:

"Communicando con el Padre Luis Gonzalez lo que el Padre Maestro Juan de Polanco me escrive de las personas que ratione generis acá se tiene por inconveniente reçebirlas, le pareçio que deviamos dar cuenta a V. P. de como en este Reyno no son como los de otras partes porque sus padres o avuelos fueron hechos christianos violentemente, y ellos mismos en su negoçios ado les puede ayudar esta causa la alegan al rey, y al mismo Padre Luis Gonzalez an venido con requerimiento de todos los desta nación en general iustificandolo con la misma razon. Tambien ay conçepto, que por acreditarse procuran de hazer algunos de sus hijos religiosos, y poco tiempo ha fueron condenados dos padres por judios publicamente en esta ciudad que en ella tenian hijos e hijas religiosas y professas, y avian hecho mucha deligençia por que se los reçibiessen en religion, y de mas desto ellos, y otros tambien condenados el mismo año frequentavan mucho los sacramientos. Por estas razones y por otras particulares de los desta naçion naturales destos Reynos, les tienen los principes y el pueblo muy poco credito, y se guardan mucho dellos como ya he escrito a V. P.".

Ainda na opinião de Luís Gonçalves da Câmara, ao escândalo dos cristãos-novos, que se queriam fazer religiosos para se acreditarem numa sociedade que lhes mostrava uma hostilidade firme e difusa, não se podia dar remédio enviando os candidatos para Roma ou para outras províncias, onde os recebessem:

(65) Carta de António Pacheco por comissão do padre Miguel de Torres, Lisboa, 1 de Setembro de 1564, em Archivum Romanum Societatis Iesu (daqui em diante ARSI), Lusitania (daqui em diante Lus.) vol. 52, fls. 140-142v; em particular fls. 140v-141. 
"Parecia más al Padre Luis Gonzalez que tanto o mayor inconveniente para esta provinçia era reçibirse subiectos desta nação naturales della, en otras provinçias por alla, de lo que seria reçibirlos aqui, por que los parientes se honran y alaban dello, y publican en las partes y entre las personas que mas haze a su caso saberlo, y como es la misma religion, que da el mismo escandalo, y embiarlos de aqui determinadamente para la Compañia para Roma y las demas provinçias agrava el negoçio, por que diran que tanto queremos esta gente que hazemos lo possible por no dexar de reçibirlos, y ya que en estos Reynos no tienen tan commodo lugar, le procuramos estotro remedio. $Y$ desto tenemos alguna experiençia por que algunos de los parientes de los nuestros que estan fuera de Portugal, y de otros que aca ay, an dado mucha occasion de pensarse que se gloriavan de sus parientes estar en la Compañia, y de ser personas en ella de cuenta de lo qual allende del conçepto cumum se ha recreçido lo que an dicho Sus Altezas, y otras personas notables. Parecia al mismo Padre Luis Gonzalez que se no dixese a ninguno que fuesse a Roma ni a otra parte dandole, ni no dandole palabra de que se reçibirian, y que se ellos tuvieren voluntad eficaz ellos iran pues saben ya que alla se reçibien".

A carta terminava com a referência a alguns pedidos de admissão de cristãos-novos, entre os quais se contavam: o irmão do reitor do colégio de Alcalá, ouvinte do curso das artes em Coimbra; dois legistas da Universidade de Coimbra que, com carta de apresentação do padre Gonçalo Vaz de Melo, tinham ido ao padre comissário, o qual não os quis receber; um de Évora "para que el Padre Maestro Nadal dexo liçençia", o qual "se fue a Sevilla, y alla le reçibieron segun dizen y escriviome el Padre Don Leon que se sabe en Evora y que ay escandalo dello"; por fim, um estudante do Colégio de S. Antão de Lisboa ${ }^{(66)}$.

Para os cristãos-novos o ambiente tornava-se cada vez mais pesado, e isso não sucedia especialmente na Companhia nos meados dos anos Sessenta, época em que, por exemplo, foram introduzidas as primeiras normas de exclusão numa das principais ordens religiosas do reino, a de S. Jerónimo ${ }^{(67)}$.

(66) Carta do padre Diego Mirón ao padre geral Diego Laínez, Lisboa, 12 de Novembro de 1564, em ARSI, Lus. 61, fls. 246-247v.

(67) Ver Cândido Augusto Dias dos Santos, Os Jerónimos em Portugal. Das Origens aos Fins do Século XVI, Porto, Gráf. Reunidos, $1996^{2}$ [1ª ed. 1980], pp. 44-50. 
Outro momento importante da história das relações entre Santo Ofício e Companhia foi o da passagem dos edifícios do Colégio das Artes, situados na parte baixa de Coimbra, à Inquisição, que foi restabelecida na cidade entre 1565 e 1566. Os edifícios deviam servir de casa para o tribunal e as cadeias. O negócio, que envolveu também o bispo João Soares - o verdadeiro promotor da refundação do Santo Ofício de Coimbra -, apresentou dificuldades, mas a Companhia mostrou-se disposta a satisfazer os desejos do cardeal, aceitando a deslocação provisória do Colégio para a parte alta da cidade. Contudo, surgiram perplexidades acerca da forma do pagamento dos edifícios por parte da Inquisição, que se pretendia fazer com o dinheiro dos confiscos dos condenados pelo Santo Ofício. Mais de uma vez, por exemplo, o padre Pedro Dias, procurador do colégio de Coimbra, tentou persuadir o padre Leão Henriques, provincial da Companhia, a partir de 1565, a que buscasse outra via que não a dos confiscos ${ }^{(68)}$.

Em geral, a incisiva capacidade de penetração dos jesuítas, o elevado número dos seus membros, o conhecimento aprofundado da realidade social e religiosa portuguesa acabaram por favorecer a decisão de envolver directamente a Companhia nas actividades da Inquisição. Tratou-se de um resultado das ligações cada vez mais chegadas entre $o$ cardeal infante, o qual, lembre-se, manteve a regência até 1568 , e a corrente rigorista e segregacionista chefiada por Luís Gonçalves da Câmara, mestre e confessor do rei D. Sebastião. A vida interna da Companhia durante estes anos era dominada por este grupo de padres, que conseguia ocupar os cargos mais importantes, como o de provincial, ocupado por Leão Henriques, desde 1565. Entretanto, o peso político dos jesuítas continuava a crescer. Em 1564 Martim Gonçalves da Câmara, irmão de Luís, foi eleito deputado da Mesa da Consciência e Ordens por iniciativa de D. Henrique.

(68) Sobre o assunto ver Francisco Rodrigues, ob. cit., t. II, vol. 1, pp. 150-155; 564-567. Ver também a carta do cardeal D. Henrique ao bispo de Coimbra João Soares, Lisboa, 6 de Outubro de 1565; a carta do cardeal infante D. Henrique aos inquisidores de Coimbra, Almeirim, 20 de Março de 1565; a carta do rei D. Sebastião aos deputados e oficiais da Inquisição de Coimbra, Lisboa, 14 de Maio de 1568; a carta do rei D. Sebastião ao padre provincial Leão Henriques, Lisboa, 28 de Fevereiro de 1566, publicadas respectivamente em Documentos para a Historia dos Jesuitas em Portugal, colligidos por António José Teixeira, Coimbra, Imprensa da Universidade, 1899, pp. 327-329; 334-335. 
Cinco anos mais tarde, no dia 14 de Junho de 1569, quando em conformidade com a bula da fundação da Inquisição o cardeal criou definitivamente o Conselho Geral do Santo Ofício, os três primeiros deputados nomeados foram Manuel de Meneses, o doutor Ambrósio Campelo e Martim Gonçalves da Câmara. Ogoverno do reino era já exercido por D. Sebastião, e foi durante os seus primeiros anos que os rigoristas atingiram o apogeu da influência nas instituições políticas e eclesiásticas lusitanas. Os irmãos Câmara foram dos principais protagonistas da vida portuguesa entre $o$ fim dos anos sessenta e o início dos setenta. D. Sebastião escolheu como seu principal conselheiro Martim Gonçalves da Câmara, ao qual foi atribuído o título de escrivão da puridade, enquanto o irmão Luís continuava a ser o confessor do rei ${ }^{(69)}$. As vozes de protesto contra o poder despótico dos Câmara não demoraram a levantar-se. Numa carta escrita em Junho de 1571 ao geral da Companhia, o padre Francisco de Borja, a rainha $\mathrm{D}$. Catarina não hesitou em definir os dois irmãos "absolutos señores del Reyno, y del Rey"(70).

Durante esta fase de extraordinário poder político dos jesuítas foi tomada a decisão de conferir um cargo oficial e estável à Companhia na Inquisição. A resolução foi precedida de alguns episódios que vieram a confirmar a confiança do cardeal D. Henrique nos discípulos de Inácio. Durante o Verão de 1570, o doutor Sebastião Vaz, que servia no Santo Ofício de Coimbra, fez uma visitação inquisitorial geral na região de Entre-Douro-e-Minho ${ }^{(71)}$. A primeira etapa foi a cidade do Porto, onde,

(69) Sobre a influência política dos irmãos Câmara ver Francisco Rodrigues, ob. cit., t. II, vol. 2, pp. 253-283; 373-392; José Maria de Queirós Veloso, D. Sebastião. 1554-1578, Lisboa, Emprêsa Nacional de Publicidade, $1945^{3}$ [1 $1^{\text {a }}$ ed. 1935], pp. 89-258; Francisco de Sales de Mascarenhas Loureiro, O papel de Martím Gonçalves da Câmara e do irmão junto do "desejado", Lourenço Marques, 1974.

(70) Carta de D. Catarina ao padre geral Francisco de Borja, Enxobregas, 8 de Junho de 1571. Uma tradução em português do documento pode ver-se em Tomás Lino de Assumpção, História Geral dos Jesuitas, Lisboa, Moraes, 1982², p. 445. Cito a partir da cópia em língua original conservada na Biblioteca da Ajuda (daqui em diante BdA), 54-XIII-12, doc. 113.

(71) A documentação conhecida sobre a visitação de Entre-Douro-e-Minho encontra-se em ANTT, Inquisição de Coimbra, Livro 660-661. Um útil extracto do Livro 660, que contém as denúncias relativas à cidade do Porto, foi publicado em Visitação da Inquisição a Entre-Douro-e-Minho, 1570, por António do Rosário, Braga, Livraria Cruz, 1978. 
no dia 4 de Junho, no fim de uma procissão solene da Sé para a igreja de S. Domingos foi publicado o édito da fé pelo reitor do colégio da Companhia, o padre Rui Vicente, que fez também uma pregação em louvor da fé católica ${ }^{(72)}$. Mas a participação dos jesuítas na visitação do doutor Vaz não se limitou a isto. Segundo o que se lê numa carta escrita, no dia 3 de Julho, por João Peres ao geral Francisco de Borja, quando ainda continuava a visitação no Porto, "por todo este mes pasado el [scil. Rui Vicente] y el padre Fernam Carvalho, el qual es grandemente acçepto de todos, en los sermones que uvo persuadieron mucho al pueblo cumpliessen esta obligacion de la inquisiçion y el inquisidor entendio bien el zelo de los padres y esta grandemente edificado de la Compañia y concedio que todos los que viniesen denunciar a este collegio satisficiesen lo que era de personas que escogian esto por poder hazerlo mas libremente a sus confessores que a el y asi en esto como en confesiones que mandaa nos ocupo bien e se hizo mucho fructo"(73).

Não é completamente claro qual foi o papel dos jesuítas do Porto durante a visita inquisitorial, mas resulta evidente que eles colaboraram activamente sendo provável que tenham recolhido as denúncias dos que costumavam habitualmente confessar-se no Colégio da Companhia, os quais conseguiam mais facilmente desencarregar suas consciências perante um jesuíta do que perante o inquisidor. A documentação sobrevivente não diz muito sobre as estratégias adoptadas pelos padres da Companhia. Só se depreende que o doutor Vaz, depois de ter ouvido a confissão judicial de alguns culpados, principalmente de judaísmo, e de os ter reconciliado, os enviou ao Colégio dos jesuítas para que fizessem também uma confissão sacramental e, depois de confessados, voltassem a certificá-lo ao inquisidor ${ }^{(74)}$. Encontram-se também dois padres entre os acusadores. Trata-se do padre Manuel Rodrigues, antigo reitor do

\footnotetext{
(72) Ver ibidem, pp. 2-3.

(73) Carta de João Peres ao padre geral Francisco de Borja, Porto, 3 de Julho de 1570, em ARSI, Lus. 64, fls. 66-68v, em particular fl. 66.

(74) Foi o caso, por exemplo, de Simão Álvares, cristão-novo, mercador, de sua filha Catarina Vaz, de Domingas Álvares, cristã-velha, de Maria Gomes, cristã-nova, e de João Eanes, cristão-velho, carpinteiro. Ver Visitação cit., pp. 3-4; $6 ; 11 ; 14-17 ; 35-36$.
} 
Colégio, o qual, no dia 13 de Junho, denunciou ao inquisidor um João Rodrigues de Sá o Velho, por ter dito que as igrejas não deviam ter outras rendas senão os dízimos, e do padre Gaspar Âlvares, o qual, a 10 de Julho, contou ao doutor Vaz que estando na cadeia secular onde fora para confessar um preso, ouviu dizer a um António Luís Barrosinho que tinha recebido um recado dum despacho que não o satisfazia, pelo que se havia de tornar luterano ou mouro, pois o não despachavam bem ${ }^{(75)}$. Em todo o caso, a visitação do Porto demonstra a existência de sintonia entre a Inquisição e uma parte da Companhia de Jesus. Uma confirmação ulterior proveio, no mesmo ano, ainda dos jesuítas do Porto. Um peregrino que tinha chegado do estrangeiro à cidade do Douro começou a propagar uma doutrina herética. Informados do facto, os padres debateram publicamente contra o peregrino estrangeiro, persuadindo os habitantes do Porto a evitar os seus erros, tendo o tal peregrino acabado por ser preso pelos inquisidores ${ }^{(76)}$.

Em 1571, finalmente, D. Henrique assentou que fosse reservado permanentemente a um jesuíta um lugar de deputado no Conselho Geral do Santo Ofício, segundo nos informa a carta anual da província lusitana:

"Esta por la bondad del Señor la Compañia bien recebida y acepta en este Reyno, assi de lo secular i ecclesiastico como de los señores inquisidores, i della se aiudan y sirven los señores temporales y perlados ecclesiasticos en negocios graves. En dos partes examinan los nuestros a los clerigos pera las confisiones y a instancia del cardenal iffante inquisidor maior concedio V. P. que un padre assistiese al Consejo General de la Inquisicion en tres partes en que ella esta. Ocupan los señores inquisidores

(75) Ver ibidem, pp. 9; 26-27.

(76) "Appulsus est in hunc portum peregrinus, qui transmarina quadam, et impia disciplina quam secum evexerat, rudiorum animos imbuere conabatur, ac non nullus etiam in errorem per imprudentiam induxerat, res nostris indicatur, hominis errores publie convincuntur, cives quomodo vitandae sunt nebulonum insidiae edocentur, ipse false opinionis autor ab inquisitoribus comprehenditur, et in custodiam traditur. Itaque parvo labore, cura tamen et providentia nostrorum, haec scintilla restincta fuit, quae si diutius inguisset, magnum fortasse incendium, quod in aliis gentibus evenisse cernimus, excitasset" (Littera Annua de 1570 do colégio do Porto, escrita por António Gonçalves por comissão do padre reitor Rui Vicente, Porto, 1 de Janeiro de 1571, em ARSI, Lus. 52, fls. 227-228v, em particular fl. 227v). 
muchas vezes a los nuestros con los presos, $y$ tratan dubdas de importancia con ellos"(77).

Nos primórdios o padre que mais assistiu ao Conselho Geral foi Leão Henriques, então confessor de D. Henrique. Assim escrevia o padre Henriques ao geral Francisco de Borja numa carta datada a 21 de Março de 1571: "Agora estou aqui em São Roque e confesso ao cardeal, o qual me ocupa não somente nisto, mas em outras cousas de sua consciencia, como he nos carregos que tem dar-me conta e atentar eu tambem nas faltas que neles podem aver e avisa-lo disso pera que ele remedee, e tambem chamar-me cada dia hum ou duas vezes a tratar cousas spirituais e de Deos $[. . .]^{\prime \prime(78)}$.

Não há dúvidas que entre os "carregos que tem", a que se referia Leão Henriques, se contassem também os da Inquisição ${ }^{(79)}$. $O$ ingresso da Companhia no principal órgão do Santo Ofício aponta para o triunfo da corrente rigorista. A partir do início dos anos setenta, portanto, as altas esferas dos jesuítas esforçaram-se por colocar à disposição do Santo Ofício as estruturas e os meios de acção social e religiosa da Companhia. Por outro lado, a Inquisição garantiu a sua protecção aos jesuítas e, ainda

(77) Littera Annua de 1571 da província lusitana, escrita por padre Luis Perpiñan por comissão do padre provincial Jorge Serrão, Lisboa, 15 de Janeiro de 1572, em ANTT, Manuscritos da Livraria 690, "Cartas Anuais dos Jesuítas. 1571$-1629^{\prime \prime}$, fl. $1 v$.

(78) Carta do padre Leão Henriques ao padre geral Francisco de Borja, Lisboa, 21 de Março de 1571, em ARSI, Lus. 64, fls. 177-179v; em particular fl. 177rv.

(79) Numa outra carta, escrita por D. Henrique ao vigário geral Polanco, logo depois da congregação provincial de 1572, convocada após a morte de Borja para eleger os delegados portugueses para a congregação geral em Roma, a referência aos cargos inquisitoriais de Leão Henriques é manifesta: "Estando o Padre Jorge Sarrão, provincial, pera partir pera essa congregação, adoeceo de maneira que pareceo que não devia de ir; e foi eleito em seu lugar o P. Lião Anrriquez, meu confessor, e de que me eu ajudo muito en as cousas da Santa Inquisição: dei-lhe licença pera ir, posto que tivesse delle muita necessidade, por me parecer que importava muito sua ida pera o serviço de nosso Senhor, e pera as cousas da Companhia por ter dellas muita experiencia, e ter a virtude, letras e mais partes que pera o tal cargo são necessarias" (Carta do cardeal infante D. Henrique ao vigairo geral padre Juan Alfonso de Polanco, Évora, 22 de Janeiro de 1573, publicada em "MHSI", Polanci Complementa. Epistolae et commentaria P. Joannis Alphonsi de Polanco, 2 vols., Madrid, 1916-1917; vol. II, pp. 228-229). 
mais, cometeu-lhes poderes cada vez maiores, sobretudo no campo da censura literária.

\section{Os cristãos-novos na Companhia de Jesus: a luta e o triunfo da corrente segregacionista}

Para uma análise mais correcta e uma melhor compreensão das relações entre a Companhia e a Inquisição durante as décadas finais do século XVI podem-se salientar três questões diferentes, mas absolutamente conexas entre si. Para maior clareza, será melhor encarar singularmente cada uma delas.

O primeiro aspecto a considerar é o das lutas no interior da Companhia acerca da presença e do papel desempenhado pelos padres cristãos-novos. Até ao início dos anos setenta, como afirmou Borja Medina, a tendência integradora, apesar de muita oposição, manteve-se dominante na província lusitana ${ }^{(80)}$. Mas, a seguir à ampliação do poder dos rigoristas, também a luta contra os cristãos-novos se tornou mais áspera. Em 1570, o cardeal opôs-se com firmeza à nova eleição, disposta pelo geral Francisco de Borja, do padre Pedro Pablo Ferrer, cristão-novo, professor de Sagrada Escritura, para chanceler-mor da Universidade de Évora. Por carta de Leão Henriques a Borja, no dia 6 de Agosto de 1570, explicava-se: "V. Padre me manda que pussesse o Padre Ferrer outra vez por canchelario na Universidade de Evora, o que eu quisera loguo fazer e sabendo o cardeal me disse que o não fizesse e V. Padre o avera assi por bem, porque era biscainho e isto sabia por via de hum seu irmão medico que andou nestes reinos e que quasi todas as religiões deste reino estavão determinadas a não receber pessoa alghuma que fosse da nação quanto mais polas em carguos publicos onde a gente toda se escandalizava"(81).

(80) Ver Francisco de Borja Medina, ob. cit., p. 580.

(81) Ver ARSI, Lus. 64, fls. 82-83v, em particular fl. 82v. Nos anos seguintes, um irmão de Ferrer, chamado Baptista ou Rafael, teólogo e médico, tentou entrar na Companhia e teve também problemas por ser cristão-novo; ver a carta do padre Pedro Pablo Ferrer ao vigário geral padre Juan Alfonso de Polanco, sem lugar, 28 de Dezembro de 1572, em ARSI, Lus. 65, fls. 297-298v; a carta do padre Pedro Pablo Ferrer ao padre geral Everardo Mercuriano, Évora, 14 de Maio de 1574, em ARSI, Lus. 66, fls. 134-135; a carta do doutor Rafael Ferrer ao padre geral Everardo Mercuriano, Ossuna, 20 de Maio de 1574, ibidem, fls. 142-143. 
A perseguição caiu sobre muitos padres cristãos-novos, ou tidos por tal. O padre Cipriano Suarez, por exemplo, um dos mais afamados mestre de humanidades da Companhia, foi sempre alvo dos ataques dos segregacionistas. Em 1570, achou abrigo num dos colégios menos sujeitos aos rigoristas, o de Braga, onde actuou como reitor até 1574, ao lado do arcebispo dominicano frei Bartolomeu dos Mártires, naquela altura um dos prelados mais tolerantes para com os cristãos-novos e mais autónomos em relação à Inquisição ${ }^{(82)}$. Contudo, a presença de Suarez não deixou de levantar protestos, como se depreende de uma carta escrita por um jesuíta do colégio de Braga ao geral Borja, em 1572. Depois de ter afirmado que no Colégio "não faltão alguns desgostos e emfadamentos", o seu autor prosseguia:

"A maior occasião que há para aver algumas cousas destas me parece que nace de não sermos os que aqui estamos todos consumados na virtude, e por isso não gostamos dos trabalhos que aqui não faltão. Este collegio he pobre e não tem casas, e por isso á aqui poucos, os quais he necessario que suprião por muitos. $E$ os que não tem muito espiritu afogan-se com tanto trabalho e assi esta he huma raiz do enfadamento. Outra tenho entendido que he mais principal: o modo do padre Cypriano Soarez, reitor deste collegio, cuja virtude posto que seja grande e ponha grande cuidado para se acomodar, contudo não pode tirar de todo o que a natureza dá, porque como quer que os portugueses sejão mais sobre $e$ malicioso não fica nada que não notem, e ainda que conheção a virtude

(82) Sobre Bartolomeu dos Mártires permito-me remeter o leitor para o meu artigo "Il governo dell'arcidiocesi di Braga al tempo di Bartolomeu dos Mártires (1559-1582). Riflessioni e documenti sull'episcopato portoghese nell'età del concilio di Trento", Archivio Italiano per la Storia della Pietà, vol. XV, 2003, pp. 81-150. As relações entre os bispos e a Inquisição em Portugal, durante a segunda metade do século XVI, foram, em geral, bastante positivas, apesar de alguns prelados (como, para além de Bartolomeu dos Mártires, António Pinheiro e Jerónimo Osório) terem optado, às vezes, por estratégias autónomas de controlo sobre a heresia. Cf. o meu artigo "'Catequização pelo medo'?" cit. Pelo contrário, a tese duma colaboração quase completa entre bispos e inquisidores é defendida por José Pedro Paiva, "Os bispos" cit., o qual retoma e desenvolve as conclusões de um precedente artigo intitulado "Inquisição e visitas pastorais. Dois mecanismos complementares de controle social?", Revista de História das Ideias, vol. 11, 1989, pp. 85-102. 
da pessoa não deixão de desgostar do modo, donde toma o demonio occasião a tirar o gosto as cousas da obediencia, e de se não ter o amor que se deve ao superior, disse tambem elle ser christão novo de todos os quatro costados. E isto não sómente o sabem aqui os mais da casa, mas segundo tenho entendido a principal gente da cidade, e em casa do arcebispo, e o vigairo geral daqui o conhece da sua terra e seus parentes e irmãos que aqui vem algumas vezes tratar em cousas de mercadoria e a mim mo tem dito algumas pessoas tomar-se isto não muito bem em casa e creo que pior fora. E se não fosse sua virtude tomar-se-ia pior, isto digo a V. P. como a pai que pode remediar tudo"(83).

Os ecos da violenta campanha dos rigoristas contra os cristãos-novos ouviram-se em Roma. Na altura da congregação geral de 1573, os delegados da província portuguesa (Luís Gonçalves da Câmara, Leão Henriques, Miguel de Torres e Inácio Martins) tentaram por todas as vias impedir a eleição para vigário geral do cristão-novo Juan Alfonso de Polanco ${ }^{(84)}$.

(83) Carta de Gaspar de Barros ao padre geral Francisco de Borja, Braga, 6 de Janeiro de 1572, em ARSI, Lus. 64, fls. 241-242v, em particular fl. 241.

(84) Em carta escrita ao Papa, a 22 de Janeiro de 1573, o cardeal, após ter apresentado o padre Leão Henriques nos mesmos termos com que o fez na carta escrita no mesmo dia ao vigário geral Polanco (citada atrás na nota 79), prosseguiu, revelando ter aceite enviar para Roma o seu confessor "também e principalmente por se tratar de negócio, como julgo, necessário não sòmente à Companhia mas a todo êste reino, e de grande pêso e momento, para poder contar a Vossa Santidade tudo o que êle sabe, viu e experimentou desta nação de neófitos ou cristãos-novos, além do que de mim recebeu, para o transmitir a Vossa Santidade. Peço a Vossa Santidade com a maior instância e com tôda a humildade que posso, que lhe dê neste ponto inteiro crédito, e em tudo o mais que em meu nome lhe disser, e o oiça com atenção e benevolência, pois dirá a verdade, movido unicamente e levado pelo zêlo do serviço de Deus, bem e proveito da Companhia. Peço também com o maior empenho a Vossa Santidade que tome as mais acertadas providências, para que nenhum cristão-novo nem alguém que pareça favorecê-los, seja eleito Geral; e que não se recebam na Companhia homens dessa raça, nem sejam nela superiores. Se não se emprega o remédio a tempo, é de temer não venha a perigar e destruir-se essa Companhia. Porquanto, se principia a relaxar-se, o que é próprio dos cristãos novos, faltando-lhe a perfeição e integridade de vida que a deve animar, sem demora cairá na sepultura. Pelo que, a Vossa Santidade rogo encarecidamente e com a maior força da minha alma, que aplique o remédio a tamanho mal, porque nesta 
Por fim, resultou eleito Everardo Mercuriano, o qual, porém, não esqueceu o espectáculo das indecorosas maquinações dos jesuítas de Portugal. Uma carta do fim de 1574 confirma como os padres portugueses, e em particular Leão Henriques, trabalharam para estorvar a eleição de Polanco: "Un letrado que se hallo en Roma en tiempo de la congregacion general, amigo del P. Leon Enriquez, me dixo que el P. hizo con que no fue electo Polanco; ya el año pasado el agente del cardenal avia escrito aca que el P. Leon Enriquez hizo maravillas sobre la eleccion, o finezas" (85).

O autor da carta era Manuel Rodrigues, o principal adversário dos rigoristas, que Mercuriano, em 1574, tinha nomeado novo provincial de Portugal, pondo fim à hegemonia do grupo chefiado por Gonçalves da Câmara. De qualquer maneira, também Rodrigues tinha uma posição segregacionista, por isso, a despeito do parcial declínio dos rigoristas, a condição dos jesuítas cristãos-novos na província lusitana não melhorou $^{(86)}$. Durante o ano de 1574, a questão da eleição do novo provincial e a dos cristãos-novos misturaram-se frequentemente. Em Janeiro, o padre Suarez escreveu uma carta ao novo geral pedindo a sua transferência:

"Yo a que estoy en la Compañia 24 años, en la mayor parte dellos se an ofreçido tantos encuentros y molestias que mi deseo es cubrirlas con perpetuo silencio y olvido y asi, supuesta la informacion que V. P. dize

diligência prestará Vossa Santidade a Deus o maior obséquio, e a mim fará o mais estimado benefício" (Carta do cardeal infante D. Henrique ao papa Gregório XIII, Évora, 22 de Janeiro de 1573, publicada em Antonio Astrain, Historia de la Compañia de Jesús en la Assistencia de España, 7 vols., Madrid, Est. Tip. "Sucesores de Rivadeneyra"-Administración de "Razón y Fe", 1912-1925; vol. III, pp. 695-696. Eu cito porém a partir da tradução do latim efectuada por Francisco Rodrigues, ob. cit., t. II, vol: 1, pp. 349-350.

(85) Carta do padre Manuel Rodrigues ao padre geral Everardo Mercuriano, sem data, escrita entre 8 de Outubro e 3 de Dezembro de 1574, em ARSI, Lus. 66, fls. 362-363v; em particular fl. 363v. Alguma tradição historiográfica jesuíta, desde Ribadeneira até Astrain, afirma que os portugueses sentiam uma aversão pessoal por Polanco e que aproveitaram a sua acendência judaica para obstaculizar a sua eleição a geral. Contra esta interpretação tomou posição Francisco Rodrigues, ob. cit., t. II, vol. 1, pp. 353-354, nota 4. A questão fica pouco clara, mas o documento citado no texto, efectivamente, deixa entrever uma acção dos jesuítas portugueses dirigida contra Polanco.

(86) Sobre a aversão aos cristãos-novos por parte do padre Manuel Rodrigues ver Francisco de Borja Medina, ob. cit., pp. 583-586. 
tener, digo que me consolare de estar en qualquiera provinçia de Hespanha que V. P. ordenare y, porque e oydo que el P. Cordeses viene a una dellas ordenandolo V. P., me consolare estar en ella. En Portugal por el mucho tiempo que lo e procurado y diversas circunstancias de las personas que lo an ocasionado no tendre la tranquilidad que V. P. a sus hijos desea. Las fuerzas por que V. P. pregunta son algo flacas por la edad ser de 50 anos o quasi, mas la salud es mediana y sin achaques. Esto es lo que me se ofrecio delante del Señor que ecrevira V. P. Donde quiera que V. P. ordenare mj residencia creo que ayudare un poco en predicar si asi me lo mandaren"(87).

Poucas semanas depois Suarez, que tinha, entretanto, deixado o cargo de reitor do Colégio de Braga, escreveu ao geral relatando a situação da Companhia em Portugal ${ }^{(88)}$. Antes de mais, tratava da congregação geral acabada havia pouco, recordando que "los Padres que fueron a Roma desta provinçia y el P. Mauricio hacen un cuerpo con el P. Luis Gonzalez el qual a tomado mucho poder sobre el P. provincial y como el P. Luis Gonzalez procede con impetu y vehemente aprehension y pasion paricular favoreciendo a unos y desfavoreciendo a otros y esta encontrado con muchas personas de la provincia y de las mas antiguas que estan sentidos

(87) Carta do padre Cipriano Suarez ao padre geral Everardo Mercuriano, Braga, 19 de Janeiro de 1574, ARSI, Lus. 66, fls. 24ro, em particular fl. 24. Poucos meses depois, sabendo que o padre Suarez estava desocupado, o padre Ferrer, que queria deixar o cargo de professor de Sagrada Escritura e de chanceler mor da Universidade de Évora, propunha ao padre geral o antigo reitor do Colégio de Braga como seu substituto. É possível tratar-se de uma tentativa de aplicar uma estratégia de promoção dos cristãos-novos na hierarquia da Companhia: "La necessidad desta Universidad se puede, si ay voluntad, facilmente supplir, porque ay muchos que pueden lier aqui Scritura y hazer officio de cancellario, como son el padre Cypriano Suarez, que esta agora desocupado en Coimbra, leyendo Mathematicas a quatro hermanos" (Carta do padre Pedro Pablo Ferrer ao padre geral Everardo Mercuriano, Évora, 14 de Maio de 1574, ibidem, fls. 134-135; em particular fl. 135).

(88) "Porque yo deseo que los padre y los hermanos que quedan en esta provinçia despues de tantas calamidades y naufragios tengan algun sosiego avisare a V. P. del estado della" (Carta do padre Cipriano Suarez ao padre geral Everardo Mercuriano, Coimbra, Março de 1574, ibidem, fls. 95-96v, em particular fl. 95). 
del y el dellos por diversos respectos desto se siguen los inconvenientes siguientes" ${ }^{\prime \prime 99}$. Em seguida, Suarez apresentava uma longa lista de defeitos e faltas atribuídas a Gonçalves da Câmara, a partir da desobediência às ordens e às recomendações provenientes da Casa do Geral, chegando a tanto que os jesuítas encarregados de escrever para Roma "lo hazen con miedo buscando maneras que sus cartas puedan ir seguras" ${ }^{\prime(90)}$. Lembrava, depois, a pretensão dos rigoristas "que todos los que fueron a Roma a la election fuesen de su cuerpo"(91). Em síntese, concluía Suarez, era um problema do carácter da nação portuguesa: "Por este pareçe que conviene poner remedio en las cosas desta provinçia con toda brevedad y tomar entera [r]is[olu]çion dellas y de la condiçion del P. provincial. Adelante para asegurar esta provinçia puede ver que serviria mucho ir sacando algunos y meter algunos buenos spiritos italianos, catalanes y valencianos que son naçiones bien quietas. Esto parece de mucha importançia porque esta naçion asi como es muj dificultosa de se dexar governar, asi tiene grandes siniestros para governar" ${ }^{\prime 22}$.

A centralidade do problema dos cristãos-novos nas lutas intestinas que dividiam a Companhia em Portugal é confirmada por duas cartas do padre Miguel de Torres, bom conhecedor da realidade portuguesa. No dia 31 de Agosto de 1574, escrevia ao geral Mercuriano: "La causa principal desta zizania en esta provincia me pareçe el odio yntrinseco que desde la mama tienen los cristianos viejos contra los nuevos". E prosseguia propondo uma solução de compromisso de sabor segregacionista: "seria grandissima parte o total remedio sy se diese orden que daqui adelante no se recibiessen y que para pacificacion de los recebidos [y par]a la union que la Compañia pide entre todos los della se pusies un grave precepto contra todos los que en esta materia hablasen unos contra otros, y para que en el tratar los unos y los otros tratasen con mucha ygualdad y fraterna charidad"(93). O mesmo tom era usado por Torres em 26 de Novembro:
(89) Ibidem, fls. 95ro.
(90) Ibidem, fl. $95 v$.
(91) Ibidem.
(92) Ibidem, fls. 96ro.
(93) Carta do padre Miguel de Torres ao padre geral Everardo Mercuriano, Évora, 31 de Agosto de 1574, ibidem, fl. 233 ro. 
"la causa total o casi unica desta molesta y perniciosa desunion era por el yntrinseco odio o aborecimiento que los cristianos viejos tienen contra los nuevos mostrado exteriormente con palabras y otras y que me parecia que podria ser grande remedio si ordenase V. P. que de aqui adelante no se admitiesen en esta provincia los nuevos, y para la paç de los ya admitidos, y union de los unos y de los otros mandase severa y estrechamente que los unos directe ny indirecte ni hablasen ny tratasen en preiuiçio ny diminuçion de los otros en publico ny en secreto, mas antes que los que oyeren a otros dello los reprehendan y avisen al superior y podria ser que este fuese bastante remedio, porque facilmente los menos principales seguiran la doctrina y exemplo de los que tienen mas authoridad y estos no ay que dudar sino que cumpliran a la letra lo que se les ordenase" ${ }^{\prime(94)}$.

No entanto, outras opiniões chegavam a Roma a partir de Portugal. No dia anterior o padre jesuíta italiano Bernardino Ferrario, que se achava em Lisboa à espera dum embarque para a Índia, tinha escrito uma carta pormenorizada ao geral sobre a questão dos cristãos-novos:

"come mi son occupato in udir le confessioni dopo che son qui, mi son occurse molte persone di molte buone parti tanto naturali, quanto di lettere, desiderose di servir N. Signore in religione et dicono di non ritrovar entrata in niuna religione de quante se ne ritrovano in Portogallo, et non solo per questo mas ne anco gli è concesso che siano clerici d'ordine sacro, et per questo non per altro sino perche tengono origine di hebrei, et questo non solo è con gl'huomini, m'anchora con le donne che desiderano di essere religiose, le quali per niun modo le vogliono admettere. La causa di questo ordine et constitutione è stata il malo esempio che alcuni di questa natione han dato de se (non pero religiosi, ma secolari, come intendo), tuttavia non mi par causa sufficiente che tutti generalmente siano privati d'un tanto bene d'esser religiosi, et mi par caso degno che Sua Santità vi ponessi alcun buon ordine di modo che havessiro li mali che timer et alli buoni non mancasse occasione d'esser più perfecti et conservarsi nelli lor buoni propositi perché in vero $\mathrm{mi}$ pare un[a] grande afflictione vidersi l'huom che, [si] vive nel stato seculare

(94) Carta do padre Miguel de Torres ao padre geral Everardo Mercuriano, Évora, 26 de Novembro de 1574, ibidem, fls. 326rv, em particular fl. 326. 
è privato di tutte sorte di honore et dignita et, si vuole lasciar il secolo, non gli e dato luoco, perche, anchorche alcuni ritrovarebbono commodita fuor di questo regno, non tutti tengono forze spirituali massime al piu di voler anchora spontaneamente andar in esilio, ne ancho altri tengono tante forze et commodia corporali di volersi esporre alli travagli del camino et di navigationi, per questo veda V. P. se si potra porre alcun remedio"(95).

Por fim, como vimos, no início de Dezembro de 1574, foi constituído provincial o padre Manuel Rodrigues, cuja aversão aos cristãos-novos não era menor da que praticava Gonçalves da Câmara e os outros rigoristas. Noutra carta, escrita entre o fim de 1574 e o início de 1575 , o novo provincial afrontava o problema, com especial referência aos portugueses que entravam na Companhia em Espanha, onde as admissões não eram limitadas pelas restrições que havia em Portugal:

"En Castilla reciben Nuestro[s] Padres en la Compañia algunos mancebos de Portugal que en esta provincia no se reciben por ser cristianos nuevos y estar esta gente mui infamada en este Reino. $Y$ despues los embian aca a visitar sus parientes, de lo qual se escandaliza el pueblo viendo que agora se reciben en la Compañia tan conocidos crisianos nuevos, y que persuaden a otros que vaian a Castilla y alla los recibiran. El año passado vino de la provincia de Andaluzia a Evora con este escandalo que digo el padre Garcia Xuarez y despues que se fue, salio un hermano suyo al cadahalso en el acto publico de la inquisicion, con lo qual se augmento el escandalo. Agora lo quiere el P. Provincial de Andaluzia embiar otra vez a Evora: impedimoslo como podemos, no see si bastara. Si viniere sera notable la infamia que aquella ciudad concebira de la Compañia"(96).

Os inícios do provincialato de Manuel Rodrigues não foram fáceis, porque os rigoristas não deixavam de representar uma ameaça e um elemento de forte instabilidade. Numa carta do início de 1575 o provincial

(95) Carta do padre Bernardino Ferrario ao padre geral Everardo Mercuriano, Lisboa, 25 de Novembro de 1574, ibidem, fls. 315-316v, em particular fl. 315.

(96) Carta incompleta do padre provincial Manuel Rodrigues, dirigida provavelmente ao padre geral Everardo Mercuriano, sem data, mas escrita entre o fim de 1574 e o início de 1575, ibidem, fl. $363 a$. 
escrevia a Mercuriano: "Los Padres que estos años passados governavan entiendo que andan mui llenos y quasi para rebentar, o rebentan ya, por no les aver succedido las cosas segun sus humores o deseños". O grupo a que Rodrigues se referia era formado, naturalmente, por Luís Gonçalves da Câmara, Jorge Serrão e Leão Henriques. Sobre o último afirmava:

"Es de temer que, como el Padre Leon Enriquez costumbra tratar muj familiarmente (etiam cosas de la Compañia) con el cardenal, venga a dezirle palabras que lo provoquen a meter la mano en la Compañia, como haze en las otras religiones. Un Padre, de quien mucho fiavan los padre Luis Gonzalez y Leon Enriquez y lo instruyan en rigores, me dixo que el Padre Leon Enriquez le dixen que no avia de traer Dios sus praedesttinados a la Compañia sino a los capuchos y a otras religiones, y que era menester hazer con el cardenal nos mandasse reformar por algum fraile jeronimo. Esto segun el timpo en que el Padre me dixo que passo no entiendo que fuesse despues de tener yo este officio, mas no a mucho que fue y hablava contra San Roque. Pareceme que el remedio es apartar estos padres, mas el Rey y el cardenal no lo consienten, porque los quieren traer consigo".

A influência dos rigoristas na corte lusitana, portanto, mantinha-se muito forte. O perigo de que eles persuadissem o inquisidor geral a intervir na vida interna da Companhia era muito elevado e não seria fácil contrastá-lo, porque D. Henrique tinha um poder enorme sobre as instituições eclesiásticas em Portugal. O padre Leão Henriques até tinha declarado que o rei e o inquisidor geral eram tão poderosos que podiam fazer depor Mercuriano: "Avisome el Padre Leon Enriquez en Evora que era necessario no saberse que V. P. pretendia sacar de la corte a el o a personas que el Rei y el cardenal queria, porque (dixo el) son poderosos el Rei y el cardenal para hazer deponer al general. Pareciame que devia escrivir esto para V. P. estar avisado de todo"(97).

Além das preocupações acerca dos rigoristas, todavia, Rodrigues mantinha um alto nível de alarmismo sobre a questão da infiltração dos cristãos-novos na Companhia. Numa outra carta enviada ao geral tratava

(97) Carta do padre provincial Manuel Rodrigues ao padre geral Everardo Mercuriano, sem data, mas escrita depois do dia 6 de Janeiro de 1575, ibidem, fls. $364 r v$. 
o problema das entradas de cristãos-novos portugueses nos colégios espanhóis: "Algunos christianos nuevos deste Reino que van a entrar en la Compañia en Castilla porque aca no los reciben, vienen aca despues a visitar sus parientes o a algunos negocios. Sientese esto ser alguna afrenta o abatimiento desta provincia, porque acontece ser algunos destos de qualidad que, si estuvieran en la provincia de Portugal, V. P. tuviera por bien embiarlos para fuera della por ser muy conocidos sus parientes y algunos penitenciados por la Inquisicion"(98).

Durante os anos seguintes a discussão prolongou-se oscilando entre as tendências segregacionistas dos portugueses e a ausência de qualquer pronunciação oficial da Companhia contra a admissão de cristãos-novos. Foi um período de transição durante o qual a hostilidade contra os cristãos-novos fez cada vez mais prosélitos e o padre Manuel Rodrigues se tornou o maior porta-voz das instâncias anti-judaicas da província lusitana. Em 1579, tentou fazer pressão sobre o geral alegando também a posição do rei Filipe II de Espanha:

"Acreçento mas Don Theotonjo que en España christiano nuevo o confeso (que asi se llama) es tan grande infamija, como en Portugal o mas, y que para un cavallero tomar algun criado se informa si es confesso y siendo lo no se atreve a tomarlo, y que algunos religiosos, antes de reçebir el que pide su religion, van muy largos camjnos a saber si es confesso, para no recebirlo. $Y$ que el Rey Filipe porque sabe que en la Compañia ay muchos en España, aunque siente bien de nuestro instituto, no se atreve a tratar con los nuestros, por no aconteçerle tratar con algun confesso. Destas cosas me parecio avisar a V. P."(99)

Pelos meados dos anos oitenta os jesuítas portugueses continuavam a pressionar o novo geral da Companhia, o italiano Claudio Acquaviva, para que introduzisse o princípio de exclusão dos cristãos-novos. Manuel Rodrigues insistia na sua posição segregacionista, chegando a defender

(98) Carta do padre provincial Manuel Rodrigues ao padre geral Everardo Mercuriano, Lisboa, 29 de Março de 1575, em ARSI, Lus. 67, fls. 63-64v, em particular fl. 63.

(99) Carta de padre Manuel Rodrigues ao padre geral Everardo Mercuriano, Évora, 4 de Janeiro de 1579, em ARSI, Lus. 68, fls. 50-52v, em particular fl. $51 v$. 
que tal era a vontade original de Inácio de Loyola, como escreveu numa carta de 22 de Abril de $1584^{(100)}$.

Em 1585, o problema dos cristãos-novos perturbava a casa de S. Roque. $\mathrm{O}$ padre Pedro da Fonseca fez vários relatórios a Acquaviva sobre a situação. Em 22 de Fevereiro, por exemplo, informava que "sientese tambiem algun affecto poco ordenado entre algunos pocos de hablar de christianos nuevos, y no tal algunos que tienen dello algo en la Compañia cosa que me daa mucha pena, porque aunque el delecto al recibir sea necessario, maxime en estas partes, despues de uno reçebido es cosa muy agena de la charidad fraterna hablar en ello, sino fuera entre superiores para no ponerle en lugar o officio de que naciesse offension del pueblo"(101).

No início dos anos noventa, um outro episódio mostrou que o clima estava a mudar na Companhia. Após prolongada expectativa, em 1591, fundou-se o Colégio de Todos-os-Santos, em Ponta Delgada, na ilha de São Miguel. Em 1568, um rico habitante da ilha, João Lopes, irmão dos jesuítas Manuel Lopes e Henrique Henriques, cristãos-novos, tinha doado aos jesuítas o rendimento de trinta moios de trigo para a fundação de um Colégio. Quando, finalmente, se instituiu o Colégio, João Lopes pretendia o título de "fundador", provocando o levantamento de uma acalorada polémica ${ }^{(102)}$. Existiam muitas razões por causa das quais os

(100) Ver a carta de padre Manuel Rodrigues ao padre geral Claudio Acquaviva, Roma, 22 de Abril 1584: "Dizese que si nuestro padre Ignacio agora viviera dexara la cosa más apertada en las Constituciones; y que aun assi como las dexo es este impedimento de la raça, según ellos, esencial o muy próximo a esencial, por la causa de la notable deformidad y infamia que en tiempo de nuestro padre Ignacio aún no era tan descubierta como agora" (citada por Francisco de Borja Medina, ob. cit., p. 585).

(101) Carta do padre Pedro da Fonseca ao padre geral Claudio Acquaviva, Lisboa, 22 de Fevereiro de 1585, em ARSI, Lus. 69, fls. 44-45v, em particular fl. 44. Ver também a carta do padre Pedro da Fonseca ao padre geral Claudio Acquaviva, Lisboa, 11 de Maio de 1585, ibidem, fls. 94-95v.

${ }^{(102)}$ Sobre a ascendência judaica de João Lopes ver Isräel-Salvator Révah, ob. cit., p. 88. Para uma parcial reconstrução histórica da polémica acerca da sua pretensão de ter o título de "fundador" do colégio da Companhia de Jesus de Ponta Delgada ver José Maria Teixeira Dias, Todos os Santos. Uma casa de Assistência Jesuíta em São Miguel, Dissertação de História da Educação, apresentada a Provas de Doutoramento, na Universidade dos Açores, 2 vols., Angra do Heroísmo 1997, vol. I, pp. 212-220. 
desejos de João Lopes eram contrariados, mas a principal era que os jesuítas não podiam aceitar a mancha desonrosa de terem um cristão-novo como fundador de um seu colégio. É o que esclarecia, em 1592, o relato do padre Fernão Guerrero numa carta enviada ao padre geral:

"Quanto al Collegio que Juan Lopez pretiende en aquella ciudad y Isla de $\mathrm{S}$. Miguel yo contava con accion e deligencia possible, he mjrado e examinado todo y en substancia lo que salle es bien que todo lo declare a V. P. conforme a mi obligacion para que vea lo que se deve hazer y primeramente es necessario declarar no que le toca a la qualidad de la persona de Juan Lopez e de la reputacion que aqua es tenido para que le myre la consideracion que se le deve tener en dalle titulo de fundador que es lo que el mas insaciablemente pretiende y por que muere aun que el diera sufficiente dote para el Collegio quanto mas no lo dando sino lo que V. P. vera en esta.

De natalibus bien oico que sabe V. P. quien sea este buen hombre, y como es de la nacion de los christianos nuevos gente por aqua tan mal vista (e principalmente en estos tiempos en que tan pocos escapam en estos reynos que no sean presos), que hablar en uno dessos es hablar en una cosa abominable y indigna de que los hombres la vean. $Y$ aun que este siempre ha probado hombre de bien en esta parte, toda via absorto per uno dellos y por que de otros tenido em mui maior reputacion que el que e hallado todo ser fingido, no dexa de creer en la opinion de los hombres como cada uno de los demas"(103).

Eram os últimos ecos de uma luta que estava a acabar. No ano seguinte, as correntes do segregacionismo conquistariam também as hierarquias romana e durante a quinta congregação geral, em 1593, os adversários dos cristãos-novos, entre os quais os mais aguerridos eram os padres portugueses, conseguiram o êxito esperado. $\mathrm{O}$ decreto 52 estabeleceu

(103) Carta do padre Fernão Guerrero ao padre geral Claudio Acquaviva, Angra, 2 de Agosto de 1592, parcialmente publicada ibidem, vol. II (Documentação Anexa), pp. 16-25; em particular p. 18. Dias Teixeira, além de alguns erros de leitura, não indica o destinatário da carta, mas pelo conteúdo, deduz-se ser o padre geral da Companhia. 
"que, em geral, ninguém dos que descendem de raça de judeus ou de mouros, se receba daqui em diante na Companhia"(104).

\section{Os inquisidores protegem a Companhia de Jesus}

O segundo aspecto que permite entender as relações existentes entre a Inquisição e a Companhia de Jesus em Portugal, nas últimas décadas do século XVI, é a firme protecção que o Santo Ofício garantiu aos jesuítas. O episódio mais exemplar aconteceu em 1576, quando o dominicano espanhol frei Alonso de la Fuente, discípulo de Melchor Cano, chegou a Portugal exportando a sua campanha de acusação contra a espiritualidade jesuíta ${ }^{(105)}$. De Lorena, onde se achava, Alonso de la Fuente decidiu passar a Portugal, entre o fim de Fevereiro e o início de Março. Foi a Lisboa onde, naquela altura, estavam ausentes o rei e o cardeal D. Henrique. Sabia, além disso, que no Conselho Geral do Santo Ofício havia um jesuíta como deputado(106). Para evitar o choque directo, dirigiu-se a Jorge Gonçalves Ribeiro, inquisidor na mesa de Lisboa, que durante os anos passados tinha sido o mais activo juiz do Santo Ofício contra os suspeitos de "alumbradismo"(107). O dominicano entregou a Ribeiro um memorial

(104) "ut nullus omnino ex huiusmodi hominibus, qui ex Hebraeorum aut Saracenorum genere descendunt, deinceps in Societatem recipiatur" (Decreta Congregationis V, decr. 52, em Institutum Societatis Iesu, vol. II, Examen et Constitutiones, Decreta Congregationum Generalium, Formulae Congregationum, Florentia, ex Typographia a SS. Conceptione, 1893, pp. 278-279; em particular p. 278). Sobre o papel desempenhado pelos jesuítas portugueses na quinta congregação geral acerca da exclusão dos cristãos-novos ver Francisco Rodrigues, ob. cit., t. II, vol. 1, p. 360. Contra o segregacionismo tomou posição o padre espanhol Pedro de Ribadeneira, que apresentou à congregação um seu parecer intitulado De prognatis genere hebraeorum Societatis aditu non excludendis, publicado em "MHSI", Patris Petri de Ribadeneira Societatis Jesu sacerdotis Confessiones, epistolae aliaque scripta inedita, 2 vols., Madrid, 1920-1923; vol. II, pp. 374-384.

${ }^{(105)}$ Sobre o assunto ver Alvaro Huerga, Historia de los Alumbrados, 5 vols., Madrid, Fundación Universitaria Española, 1978-1994; vol. I, Los Alumbrados de Extremadura (1570-1582), pp. 160-223.

(106) Ver ibidem, p. 163.

(107) Para a acção inquisitorial contra os "alumbrados" portugueses ver José Sebastião da Silva Dias, ob. cit., em particular o capítulo IX, O iluminismo e suas manifestações, pp. 363-407. 
de denúncia contra frei Luís de Granada e os padres da Companhia de Jesus. O documento acabava com o pedido da licença de pregar em Lisboa, Évora, Coimbra e nos outros lugares onde se achavam os jesuítas para descobrir a heresia deles ${ }^{(108)}$. Sem esperar resposta, por conselho de Ribeiro, frei de la Fuente passou a Évora, onde encontrou o cardeal infante D. Henrique, ao qual também deu outro mais breve memorial ${ }^{(109)}$. Depois, foi ao convento de S. Domingos, onde achou o provincial da Ordem, frei Estêvão Leitão, e entregou-lhe um outro memorial para o provincial o transmitir aos professores da Universidade de Coimbra e aos inquisidores do reino ${ }^{(110)}$. Tratava-se duma tentativa alargada de ataque e perseguição, mas o frade espanhol não encontrou aliados propensos a colaborar, nem sequer entre a Ordem dominicana ${ }^{(111)}$. Diferentemente da Espanha,

(108) O documento está publicado em Alvaro Huerga, Historia cit., vol. I, pp. 443-451.

(109) O documento está publicado ibidem, pp. 454-454.

(110) $\mathrm{O}$ documento, entregue a frei Leitão, no dia 18 de Março de 1576, está publicado ibidem, pp. 455-465.

(111) As relações entre a Companhia de Jesus e a Ordem de S. Domingos em Portugal durante o século XVI foram menos difíceis do que em outras partes, graças também à grande colaboração que existiu entre os jesuítas e alguns dos principais dominicanos, como frei Luís de Granada e frei Bartolomeu dos Mártires. Contudo, não faltavam precedentes de outros ataques dos dominicanos contra os jesuítas em Portugal, apesar de estes ataques remontarem a muitos anos antes. Em 1549, por exemplo, o abade Pedro Domenech conheceu em Lisboa um frade dominicano castelhano, capelão de D. Henrique, que tinha grande hostilidade à Companhia (ver José Sebastião da Silva Dias, ob. cit., p. 658). Em carta de 1553 Melchior Cota contava que os jesuítas "en algunos an allado contradiçion, no tanto de los seculares como de los ecclesiásticos, en espeçial de hun çierto fraile predicador, que hizo sermones exprofesso contra ellos y su modo de proceder. De uno me contaron que, estando el P. Miron presente oiéndole, desdel principio hasta la fin no hizo otra cosa sino dezir lo que le pareçia contra la Compañia y los Padres, descendiendo ha algunas particularidades. Los de la villa que le oian, como estavan muy afficionados á los Padres y á la Compañia, y disgustaban de le oir, tanto que dezian entre sy mal del pobre fraile; y algunos ubo que mandaron llevar las sillas y saliéronse de la predicaçion; otros dezian al P. Miron que el fraile era simple, que no devia hazer caso del ni de sus palabras, porque ellos le conoçian y sabian que no era cosa, etc. El P.e Miron se reia y mostrava contentamiento y alegría. Acabada la predicaçion, le fué el P.e Miron [á] aguardar, para que en saliendo del púlpito le besase la mano, y hincóse de rodillas delante dél, mirándole todo el pueblo y pidióle la mano: el fraile se la 
em Portugal não existiam contrastes significativos entre a Companhia de Jesus e as outras instituições eclesiásticas, a partir da Inquisição. Não somente as acusações de frei Alonso de la Fuente não foram sequer tomadas em consideração, mas o cardeal infante, depois de uma reunião em que participou também frei Leitão, decidiu defender os seus principais colaboradores, como eram Luís de Granada e os jesuítas, e passar ao contra-ataque, propondo um castigo exemplar para o frade espanhol ${ }^{(112)}$.

O episódio acabou por provocar um choque relevante entre os inquisidores gerais dos dois reinos peninsulares. D. Henrique ordenou ao seu capelão e secretário particular, Manuel Antunes, que fosse a Espanha como embaixador extraordinário para seguir de perto o negócio da punição de frei Alonso de la Fuente. A questão prolongou-se durante algum tempo, porque o inquisidor geral Gaspar de Quiroga não tinha intenção de castigar um antigo informador do Santo Ofício como era Alonso de la Fuente. O embaixador português achou valiosos aliados nos jesuítas espanhóis e, em particular, os do colégio de Madrid, onde ele mesmo residia, os quais esperavam aproveitar a acção do inquisidor geral de Portugal para se vingarem das perseguições do frade dominicano. O objectivo era uma firme condenação de Alonso de la Fuente ${ }^{(113)}$. Por fim, em 1577 o frade foi submetido a um procedimento inquisitorial em Sevilha. Quando o caso chegou ao Conselho Geral, os deputados, que bem conheciam o temperamento de Alonso de la Fuente, decretaram

dió, y él la besó; y más movimiento hizo esto en los coraçones de los que vieron que hun muy buen sermon; porque muchos se movieron á lágrimas de ver la humildad del Padre. Es verdad que otros con zello grande no podian sufrir lo que vian hazer al fraile y dizian algunas palabras duras contra él" (Carta de Melchior Cota por comissão do padre Manuel Godinho ao padre geral Inácio de Loyola, Coimbra, 2 de Janeiro de 1553, em "MHSI", Litt. Quadr., vol. II, pp. 92-97, em particular p. 95). Em geral, sobre as disputas entre jesuítas e dominicanos ver a obra manuscrita do padre jesuíta Pierre Poussin, Historia controversiarum quae inter quosdam e S. Praedicatorum Ordine et Societate Iesu agitatae sunt ab anno 1548 ad 1612 sex libris explicata, em ARSI, Historia Societatis 143; com especial referência a frei Alonso de la Fuente, ver pp. 30-39.

(112) A reunião teve lugar em Évora a 24 de Março de 1576, ver Alvaro Huerga, Historia cit., vol. I, p. 168.

${ }^{(113)}$ Sobre todas as tentativas de D. Henrique e dos jesuítas portugueses e espanhóis de fazer castigar frei Alonso de la Fuente, cf. ibidem, pp. 169-212. 
que se parasse o processo e que o frade fosse deixado em liberdade ${ }^{(114)}$. De qualquer maneira, além do êxito da pressão a favor dum castigo exemplar para frei de la Fuente, todo o acontecimento contribuía para estritar ainda mais os já fortes laços da aliança entre a Companhia de Jesus e o Santo Ofício, dando um claro sinal a todos os potenciais inimigos dos jesuítas em Portugal.

\section{Os jesuítas ao serviço dos inquisidores}

O terceiro e mais interessante aspecto das relações entre as duas instituições é o da colaboração directa dos jesuítas nas actividades inquisitoriais. Podem-se determinar três âmbitos principais de intervenção. Antes de mais, o do Conselho Geral. Nos primórdios dos anos setenta o cargo de deputado foi ocupado por Leão Henriques, substituído por Jorge Serrão, cuja nomeação remonta a 5 de Janeiro de 1579. Ao lado deles é necessário lembrar também Martim Gonçalves da Câmara, cujas ligações com a Companhia eram muito íntimas. Os deputados jesuítas contribuíam para definir as estratégias gerais da acção do Santo Ofício, por via de instruções e consultas enviadas aos inquisidores e das trocas de correspondência com os tribunais locais. Às vezes intervinham directamente nos processos mais importantes, não somente fornecendo pareceres durante as várias fases processuais, mas até, dirigindo-se pessoalmente aos tribunais locais para organizar as operações.

Assim aconteceu no caso da "conjuração de Beja" (um intrincado episódio de denúncias cruzadas, em que alguns cristãos-velhos foram acusados de judaizarem $\left.{ }^{(115)}\right)$, quando, no Verão de 1572, no momento mais delicado das averiguações judiciais, D. Henrique enviou a Évora Leão Henriques, acompanhado por um outro deputado do Conselho Geral, Manuel de Quadros, para esclarecerem a complicada situação que se vivia. No dia 29 de Julho, D. Henrique escrevia aos inquisidores de Évora: "posto que eu tenha provido em tudo o que até hora me pareceo

(114) Ver ibidem, pp. 212-217.

(115) A chamada "conjuração de Beja" (1570-1574) não foi ainda atingida pelo estudo aprofundado que mereceria. Entretanto, ver António Borges Coelho, Inquisição de Évora. Dos primórdios a 1668, 2 vols., Lisboa, Editorial Caminho, 1987; vol. I, pp. 314-320. 
necessario e vos procedais nelle com muita consideração e prudencia, sam taes os inconvenientes que se podem seguir, que não bastam pera elles remedios ordinarios e comuns. Pello que, com parecer do Conselho, mando a essa cidade e casa o padre Liao Anrriquez e o licenciado Manuel de Coadros, pera que todos pratiqueis e examineis mui particularmente tudo o que for necessario e tiver difficuldade e pera que todos saibão, em qualquer evento, que não deixei de applicar a este caso todos os remedios, que parecéram necessarios"(116).

Os dois deputados ficaram em Évora um mês, o tempo necessário para resolver os casos mais graves. No dia 2 de Setembro, D. Henrique voltou a escrever aos juízes do Santo Ofício eborense:

"polo padre Lião Anriquez soube o cuidado e diligencia que em tudo o que toca a esse Santo Officio pondes e o trabalho que nisso levais, e particularmente agora em examinardes a conjuração que temeis que os christãos novos fizerão contra os christãos velhos do que, depois de descuberto de todo, não pode deixar de se seguir grande serviço a Nosso Senhor e grande credito e reputação a esse Santo Officio e casa, pois cousa semelhante se não pode encobrir (por mais que os conjurados fizessem) sem se saber e castiguar, como merece de que se seguira não ousarem mais a cometer, nem inventar cousa semelhante, polo que vos agradecerei muito levardes este negocio polos termos que o padre Lião Anriquez me disse que levaveis $[\ldots]^{\prime \prime(117)}$.

Poucos meses depois, no dia 14 de Dezembro, os quatro cristãos-novos julgados responsáveis da presumida conjuração foram condenados à fogueira.

Os outros dois âmbitos de cooperação entre a Companhia e a Inquisição pertenciam à esfera da regular actividade dos jesuítas, que punham à disposição dos inquisidores a capacidade de obter importantes informações pelos tradicionais ministérios da Companhia: a prática das missões e a administração do sacramento penitencial. Segundo o que se lê no manuscrito da História da fundaçam e progresso da Casa de Sam Roque, cuja

(116) ANTT, Inquisição de Évora, Livro 72, fls. 105-106v, em particular fl. 105.

${ }^{(117)}$ Carta do cardeal infante D. Henrique aos inquisidores de Évora, sem lugar, 2 de Setembro de 1572, ibidem, fl. 72 da segunda série de numeração. 
versão final é de 1587, os jesuítas "algumas vezes hião a missões fora da cidade" por conta do Santo Ofício $^{(118)}$. Não devia tratar-se dum cargo que todos os jesuítas aceitavam de boa vontade, porque muitos sentiam a distância existente entre os violentos métodos inquisitoriais e as formas de intervenção mais suaves, marcadas pela misericórdia e a propensão ao perdão, mais conformes com o espírito e o estilo original da Companhia. Contudo, muito dificilmente os padres podiam escapar a um encargo que lhes havia sido confiado pela Inquisição. $\mathrm{O}$ caso do padre Diogo Coelho, um jesuíta do Colégio de Bragança encarregado, no fim de 1572, de fazer alguns inquéritos por conta dos inquisidores de Coimbra, é disso claro exemplo. A carta pela qual o padre enviava aos juízes de Coimbra os resultados das suas indagações, começava com um longo passo, que exprimia o dissídio interior do jesuíta português:

"O desejo que tenho de ver nestas partes exaltada a nossa santa fe catholica e a alegria que levaria em ver toda esta gente com novo lume nela, me faz parecer a grande carga que vs. ms. me puserão menos carregada e molesta. E posto que a suavidade do praecepto e obedientia qual me foi imposta pela authoridade apostolica aleviava o jugo, todavia não deixei de sintir o pezo dela. Porque alem de não ser de minha profissão, estado e vida o entender em negocios judiciais, ainda que tocantes a fe e augmento dela, ajunta-se a isso minha insufficientia e inhabilidade, a qual bastava para vs. ms. arecearem de me cometerem cousas desta qualidade".

O padre Coelho aconselhava os inquisidores a terem em consideração que "nem a mim, nem a pessoas de nossa Companhia devem de cometer, nem mandar semelhantes cousas, ainda que assi nisto como em o de mais professamos todos a obedientia e inteira resignação de nossas vontades a Se Apostolica e aos officiais e praesidentes do Santo Officio, como filhos que somos obedientes a cadeira de S. Pedro e ajudadores na vinha do Senhor". E os inquisidores não deviam esquecer que fora o padre Coelho

(118) Historia da fundaçam e progresso da Casa de Sam Roque, e padres e irmãos de notavel exemplo e virtudes que nella faleçeram ou frutificaram, e cousas mais notaveis conforme à ordem de N. Pe Geral Claudio Aquaviva, e começa do anno de 1553, em Biblioteca Nacional de Lisboa, cod. 4491, Livro I, cap. VII, fl. 6 rv (a numeração é minha). 
o primeiro que lhes tinha escrito, "porque como medico humano quis curar com brandura o doente que achei desposto, que bem entendi poder-se fazer com maior satisfação de vs. ms. e quietação por ventura do penitente se logo o remetera a vs. ms., mas como digo a humanidade me venceo e zelo que tinha e tenho de ver a todos ajudados e alevantados com brandura quanto puder ser". Por isso, continuava o jesuíta, "peço a vs. ms. como fraco, que daqui por diante me não ponhão em semelhantes cargas pois entendem que não he de nossa Companhia exercitar-se ex professo nestas cousas, nem ainda que em alguns se aja de sofrer em mim nnao parece conveniente, pois se conhesce minha insufficientia e inhabilidade". Contudo, depois do longo desabafo, Coelho aceitava colaborar com os inquisidores, justificando assim o seu comportamento:

"certo que primo ingressu fiquei algum tanto perplexo em as commissões, porque por huma parte obstava o não ser de nossa profissão este negotio tam de proposito e a duvida de vontade do superior fazia ainda a cousa mais indifferente; por outra parte ser cometido por vs. ms. isto, que neste caso são tambem meus superiores, a quem devo obedientia polas vezes que tem da Se Apostolica. Mas livrou-me da perplexidade e duvida o precepto que nelas poserão dizendo, et authoritate apostolica mandamos, ao qual não achei effugio, mas recebendo a carga fiz a diligentia, não constrangido, mas com alegre animo e prompta vontade, pelo desejo que tenho de ver prosperada em tudo nossa santa fé"

O padre Coelho revelava aos inquisidores todas as aflições e agitações interiores escondidas atrás da zelosa obediência às autoridades do Santo Ofício. Contudo, tinha cumprido com cuidado a sua tarefa, fornecendo não somente as informações pedidas sobre João de Morais, um homem muito velho preso pela Inquisição de Coimbra sob acusação de luteranismo, mas relatando também muitos outros casos, que se referiam sobretudo a cristãos-novos e de que tinha notícias recolhidas durante a sua regular acção de religioso ${ }^{(120)}$.

(119) Carta do padre Diogo Coelho aos inquisidores de Coimbra, Bragança, 6 de Janeiro de 1573, em BdA, 49-IV-26, "Vários papeis sobre a Inquisição", doc. 3.

${ }^{(120)}$ João de Morais, cristão-velho, de família nobre, morador em Vinhais, foi preso pelo Santo Ofício de Coimbra, a 26 de Janeiro de 1572, acusado de ter proferido proposições heréticas e ter lido livros defesos. Saiu no auto-da-fé celebrado em Coimbra, a 7 de Junho de 1573, condenado à abjuração de vehementi 
Aliás, durante as normais actividades das missões no interior, ou durante as deslocações duma cidade a outra, quando os jesuítas reconheciam casos suspeitos de heresia, tentavam dirigi-los à Inquisição. Por exemplo, .em Agosto de 1579, dois jovens membros da Companhia, Duarte de Meneses e Belchior Paulo, que iam de Gouveia a Coimbra, pararam numa pequena venda junto da ponte da Mocela, na estrada entre Seia e Coimbra. Determinaram passar ali a noite. Sem os jesuítas causarem preocupação, as conversas que eles tiveram com o vendeiro e, a seguir, com alguns dos habitantes locais, durante um sermão, permitiram-lhes descobrir um cristão-novo judaizante. Sem demora, os jesuítas escreveram uma carta pormenorizada de denúncia aos juízes do Santo Ofício de Coimbra:

"Aos 21 dias do mes d'agosto de 1579, em huma venda que esta junto da ponte de Mocella da parte de leste, quoatro legoas de Coimbra na estrada que vai pera Sea vindo nos Duarte de Meneses e Belchior Paulo ambos da Companhia de Jesus do Spirito Sancto de Gouvea e anoutecendo-nos em o dito lugar de Mocela onde dormimos aquella noite aconteo que estando nos falando de Deos se chegou a nos hum homem que dizião ser o vendeiro da dita venda e nos disse: 'Padre, que direis vos d'hum homem que diz que Deos não tem chagas?', e contando a cousa como passara disse: 'Os dias passados estando aqui huma pessoa doente ou pera morrer e chamando pollas chagas de Deos, disse este homem: Calai, calai-vos que Deos não tem chagass. A isto estavão presentes cinquo pessoas, huma das quais the disse: Calai-vos, não digais isso, que por isso vos levarão as casinhas. E com isto se calou. Isto vio', disse elle 'huma filha minha e não eu e indo-me eu confessar com hum letrado me não quis asolver ate não ir dar conta disto, mas eu o não fui nunca dizer porque este homem he casado com huma irmã de minha molher e he aqui meu vezinho'. Isto disse o vendeiro. E não somos bem lembrados se nos disse que hera christão novo e tambem nos disse que o pai deste se deitara d'hum ponte no rio $\mathrm{e}$ fora enterrado no monturo.

e à pena de dois anos de cadeia, ver ANTT, Inquisição de Coimbra, processo 8725. A sentença foi publicada em Elvira Cunha de Azevedo Mea, Sentenças da Inquisição de Coimbra em metropolitanos de D. Frei Bartolomeu dos Mártires (1567-1582), Porto, Arquivo Histórico Dominicano Português-Movimento Bartolomeano, 1982, pp. 305-306. 
Depois disto estando nos fazendo a doutrina a noite a gente do lugar e chegando a lhes ensinar as partes da penitencia e de como se avião de aparelhar pera a confissão, acodio hum homem dos que ali estavão presentes dizendo: 'Padre, dizei alguma oração a esses meninos por que isso não lhes fica', e dizendo-lhe os que estavão presentes: 'Aquillo disse pera vos e para os outros que aqui estão', respondeo elle: 'Tudo aquillo eu sei tambem como elle', repetindo estas e outras semelhantes palavras. E depois nos disserão que aquelle hera christão novo e que se chamava Foão Anriquez, donde nos juntamente con outras circunstancias collegimos ser este o que disse que Deos não tinha chagas"(121).

Também pelas muitas confissões sacramentais que ouviam durante as missões, os jesuítas podiam descobrir hereges e, conforme às indicações do Santo Ofício, remetê-los para os inquisidores ${ }^{(122)}$. Não era raro um caso como aquele de André Fernandes, cristão-velho, alfaiate, morador em Brinches, perto de Serpa, o qual teve dúvidas durante algum tempo sobre o facto de que "sem o bautismo ninguem se podia salvar". Tinha falado da sua opinião com alguns letrados e sacerdotes, sem nunca tornar públicas as suas ideias. Na Quaresma de 1583, durante a confissão, tinha

(121) Carta de Duarte de Meneses e Belchior Paulo aos inquisidores de Coimbra, sem lugar nem data, em ANTT, Inquisição de Coimbra, Livro 79, fls. não numeradas.

(122) Além do problema da aplicação, ou não, em Portugal do breve de Paulo IV de 1559, a Inquisição tinha já estabelecido no capítulo VI do Regimento de 1552 que o édito da fé devia declarar que "todos os que souberem algumas cousas contra alguma ou algumas pessoas de qualquer estado e quallidade que sejão tenham feito ou dito contra a nosa santa fé catolica e Santo Officio da Inquisiçam o venhão notificar e denumciar ao inquisidor [...] e [...] o que assi souberem tocando à Santa Inquisiçam nam o diguam ne descubram a alguma pessoa de quallquer qualidade que seja, salvo a seus confessores sendo taes pessoas que lhes possam bem aconselhar o que sam niso obriguados a fazer e os confessores lhe mandarám que o venham loguo denunciar aos inquisidores" (publicado em António Baião, ob. cit., doc. XXXI). Assim, por exemplo, no édito da fé promulgado em Lisboa, a 12 de Fevereiro de 1594, declarava-se: "E auctoritate appostolica mandamos aos theologos e confessores, que tenham muito tento no conselho que devem aos culpados e denunciadores que com elles se forem aconselhar $e$ quanto for possivel os movam a vir confessar suas culpas, tirando-lhes o medo e declarando-lhes com quanta misericordia seram recebidos e avizando aos denunciadores da grande obrigação que tem a virem denunciar" (cf. ANTT, Conselho Geral do Santo Oficio, Livro 369, fls. 303-308). 
revelado o seu erro ao cura de Brinches, padre João Nunes, o qual não o quis absolver e dirigiu-o para um padre jesuíta que estava em Serpa a pregar e administrar os sacramentos. André Fernandes foi ao padre da Companhia, mas, segundo o que declarou ao inquisidor de Évora, no dia 9 de Abril do mesmo ano,"posto que tem a bulla da Trindade e lhe dizia que o absolvesse por ella, o não quiserão absolver e o mandarão que viesse a esta mesa"(123).

O episódio antecedente abre a porta sobre o universo das relações entre a Companhia e a Inquisição com referência à esfera do sacramento da confissão. Trata-se de uma questão de notável importância, que envolve o conjunto das posições mais gerais dos jesuítas para com o Santo Ofício. Desde a fundação, a Companhia de Jesus entregou-se com grande ardor aos ministérios espirituais, entre os quais assumiu um lugar central a administração do sacramento penitencial. Momento fundamental na obra de direcção das consciências dos fiéis, os jesuítas transformaram a confissão numa prática cada vez mais difusa na sociedade portuguesa. Eles tornaram-se rapidamente os especialistas da consiência e os confessores mais procurados pelo penitentes ${ }^{(124)}$. Não tiveram êxito fácil, porque encontraram muitas resistências de clérigos de outras tendências espirituais que, por vários motivos, tinham suspeita da acção dos jesuítas neste âmbito e, em particular, da luta deles a favor da confissão e comunhão frequentes. Por exemplo, durante a Quaresma de 1552, o padre Gonçalo Vaz de Melo, que se achava em missão no Algarve, teve que enfrentar em Lagos uma violenta campanha de agressão verbal e de intimidações contra os que acediam frequentemente aos sacramentos. A rebelião foi conduzida por um frade visitador da diocese. Após um silêncio inicial, o jesuíta decidiu desafiar o frade, convidando-o a ter com ele um debate público sobre a prática dos sacramentos frequentes. $O$ frade acabou por admitir a superioridade dos argumentos aduzidos pelo padre Vaz de Melo e retratou-se publicamente. A vitória definitiva do missionário da Companhia foi sancionada pela intervenção do bispo do Algarve, João de Melo e Castro, de acordo com o referido numa crónica manuscrita do século XVII:

(123) Confissão de André Fernandes apresentada ao inquisidor de Évora no dia 9 de Abril de 1583, em ANTT, Inquisição de Évora, Livro 10, fls. 250v-252v.

(124) Ver John W. O'Malley, ob. cit., pp. 151-168; Adriano Prosperi, ob. cit., pp. 440-444; 484-507. 
"Divulgada esta publica retractação, se principiou tambem a dissipar este nublado; e de todo se desvaneceu a tempestade, quando o reverendissimo e excelentissimo bispo ordenou a este reverendo visitador, que fosse aos mesmos pulpitos, em os quais tinha pregado, e junto o povo todo no maior concurso se desdicesse do que tinha ditto, e pregasse persuadindo a todos a frequencia dos Sacramentos"(125).

Em Portugal, as últimas oposições à frequência dos sacramentos foram vencidas depois do fim do concilio de Trento, que relançou com força a centralidade da confissão. Também o cardeal infante se resolveu a favorecer o acesso frequente aos sacramentos. Em 1565, imitando o que já tinha feito havia dois anos o arcebispo de Braga frei Bartolomeu dos Mártires, D. Henrique pediu ao Papa Pio V uma bula de indulgência plenária em forma de jubileu para os súbditos da arquidiocese de Lisboa, que naquele altura ele governava. À concessão da bula seguiu-se uma provisão sua pela qual evidenciava os privilégios contidos na dita bula, exortando os fiéis a confessarem-se e a comungarem, não somente na Páscoa, mas também nas outras quatro principais festividades litúrgicas do ano: o Natal, o Pentecostes, a Assunção e o dia de Todos-os-Santos. A provisão declarava que a frequência dos sacramentos era o remédio mais eficaz contra os erros da vida espiritual e que a experiência ensinava "que as pessoas que muitas vezes os recebem, ordinariamente vivem de muy differente maneira, do que vivem os que se descuidã em os receber". Por isso admoestava os fiéis a que "não somente nestas festas, mas tãbem em todas as outras, procurem frequentemente receber estes divinos Sacramentos, \& todas as mais vezes que poderem, segundo o conselho de seu prudente confessor". A intervenção de D. Henrique sintonizava-se com o grande esforço dos jesuítas para introduzir a frequência dos sacramentos. Por esta causa as duras penas estabelecidas na provisão para quem falasse contra a confissão e a comunhão frequente foram sentidos pelos jesuítas como a autorização oficial da doutrina defendida pela Companhia. A provisão de D. Henrique afirmava, de facto, que "nenhuma pessoa ecclesiastica, inda que seja regular de qualquer ordem, ou secular de qualquer qualidade e condiçã que seja, presuma prègar, ensinar, ou amoestar o contrario, publica, ou occultamente, per qualquer

${ }^{(125)}$ Ver Chronica dos PP. Jezuitas cit., pp. 445-446. 
modo. E a pessoa que contra isso for, saiba certo que se procederá contra elle, \& lhe sera dado grave castigo, como sua culpa merecer"(126).

Sobretudo a partir do fim do concilio de Trento os inquisidores fizeram uma contínua pressão sobre os sacerdotes para que eles transformassem o sacramento da penitência numa arma à disposição do Santo Ofício. O confessor alcançava a consciência dos homens e chegava a conhecer os segredos deles. Os inquisidores, por um lado, procuravam obter informações úteis dos confessores, por outro, estes actuavam como agentes da Inquisição negando a absolvição aos penitentes que descobriam erros heréticos e mandando-lhes que fossem à mesa inquisitorial para se denunciarem ${ }^{(127)}$. Os jesuítas, naturalmente, achavam-se dentro deste sistema. Mas com referência a estas práticas a Companhia nunca teve uma linha unitária. Havia padres que recusavam abrir aos inquisidores os segredos da confissão. Por exemplo, durante a visita inquisitorial de Braga, em 1565, o inquisidor Pedro Álvares de Paredes mandou chamar o jesuíta António Mendes para ser perguntado sobre uma conversa suspeita acerca do Santíssimo Sacramento que tinha tido com uma Catarina Fernandes. Às insistentes interrogações do inquisidor, o jesuíta respondeu "que nam lhe lembra. Que bem poderia ser que fosse a dicta molher falar com elle, mas nam em sua lembrança. E se alguma cousa lhe dissese, seria em confissão"(128).

${ }^{(126)}$ A provisão dada pelo cardeal infante D. Henrique é datada a 20 de Julho de 1566. Um exemplar impresso original, mas rasgado, encontra-se em BNL, Res. 804//3 V. Uma cópia foi inserida nas Constituições Extravagantes do Arcebispado de Lisboa (Lisboa, António Gonçalves, 1569), const. IV, Dos grandes bens spirituaes, que alcanção os que frequentão os Sacramentos da confissam, E sagrada cõmunhão: E da diligencia que os Rectores acerca disto devem fazer, ff. 4-6v. Acerca da reacção positiva dos jesuítas à provisão ver Baltasar Teles, ob. cit., t. II, pp. 188-189.

(127) Para uma visão global sobre as relações entre a confissão sacramental e a Inquisição em Portugal, permito-me remeter o leitor para o meu artigo "'Catequização pelo medo'?" cit., pp. 178-193.

${ }^{(128)}$ Denúncia do padre António Mendes contra Catarina Fernandes, datada a 9 de Fevereiro de 1565, publicada em Livro da Visitação que se [a Inquisição] fez na Cydade de Braga e seu Arcebispado [1565], por António do Rosário, Porto, Arquivo Histórico Dominicano Português-Movimento Bartolomeano, 1974, p. 35. Ojesuíta foi mandado chamar pelo inquisidor a seguir à denúncia de Cecília Fernandes contra João, filho de Catarina Fernandes, datada a 21 de Janeiro de 1565, em que a denunciante tinha invocado o nome do padre Mendes (ver ibidem, pp. 11-12). 
Aliás, a confissão sacramental era um âmbito que tendia a escapar ao controlo do Santo Ofício e alguns jesuítas inclinavam-se pelas várias soluções para praticar uma gestão suave da heresia, oferecidas por jubileus, bulas especiais e, sobretudo, pelo privilégio de absolvição no foro da consciência que a Companhia se vangloriava de possuir, mas acerca do qual se devia observar o silêncio absoluto. Juntamente à faculdade dos bispos de absolver da heresia oculta concedida pelo Concilio de Trento, o privilégio de que gozavam os jesuítas constituía um sistema alternativo ao da Inquisição, a qual o receava, propendendo à negação da legitimidade de qualquer poder de bispos, ordens religiosas e confessores sobre o crime de heresia. Por exemplo, em 1564, o provisor de Coimbra mandou prender um mestre João, cristão-novo, por andar excomungado por não ter cumprido a obrigação da confissão anual. Após poucos dias o réu foi transferido ao Santo Ofício de Lisboa, onde foi processado. Durante o interrogatório, de 8 de Janeiro de 1565 mestre João declarou que durante o ano passado, quando se achava no cárcere eclesiástico de Coimbra, tinha confessado os seus pecados a um padre jesuíta e "lhe comfesou que avia tanto tempo como se não comfesava, sómente que se encomendava ao Santissimo Sacramento, e lhe dise o dito apostolo que era isto mal feito em se não comfisar tanto tempo e ho asolveo"(129). Contudo, os inquisidores de Lisboa, como era previsível, não reconheceram a validade da absolvição do jesuíta de Coimbra e acabaram por condenar mestre João à abjuração pública durante o auto-da-fé de 1 de Julho de 1565 . Ao contrário, um episódio semelhante, também ocorrido em Coimbra, durante 1563, revela uma conduta dos jesuítas completamente diferente. Uma carta, datada a 1 de Setembro de 1563, relata:

"Acontecio agora venir por aqui muchos para las galeras por diversas vezes y muchos dellos venian sin se confessar avia tiempos, yvan luego alla de casa algunos padres a confessarlos y tambien se les djeron missa y dieron el Sanctissimo Sacramento. En estos presos avia un hombre honrado el qual mando pedir a este collegio un padre letrado para communicar con el certa dubda que tenia, y yiendo alla el padre diole

${ }^{(129)}$ Interrogatório de mestre João de Coimbra, datado a 8 de Janeiro de 1565, em ANTT, Inquisição de Lisboa, processo 1609, fls. 23 ro. 
cuenta de algunas cosas que avia visto hazer a un su sogro y a una sua suegra y palabras que le avia oydo que eran contra nuestra santa fee y pertenecian a yudaismo pediendole consejo y el padre le dixo que era obrigado a denunciar dellas luego animandolo a tener mas en cuenta con la honra de nuestro Señor y con la salvaçion de su anima que con los inconvenientes que en aquello se le podian representar lo qual el tomo de mui buena voluntad y dixo que avia dias que traya esta dubda y puesto que en otras partes por donde anduvo avia algunos letrados nunca se satisfizo delo communicar con ninguno esperando venir aqui para lo communicar con los padres de la Compañia que pues el le dizia que avia obligaçion que lo haria luego. Viendo el padre su buena determinaçion fue luego a dar cuenta al vicario desta ciudad a quien perteneçe tomar estas denunçiaçiones para las mandar a la Santa Inquisiçion y hizolo venir a la carçel con un escrivano adonde el preso depuso todo lo que sabia mui largamente. Quedo el vicario muj edificado desta obra y dizia al padre que no podia ser menos si no que por los de la Compañia avia nuestro Señor de descubrir cosas semejantes por el zelo que tienen de su honrra y de defender y dilatar su santa fee"(130).

Portanto, no primeiro caso, o confessor jesuíta actuou como um possível concorrente do Santo Ofício absolvendo um excomungado, enquanto, no segundo exemplo o padre da Companhia prestou-se a colaborar activamente com o vigário e, consequentemente, com a Inquisição. Às vezes esta duplicidade descortina-se na mesma pessoa, como aconteceu ao padre Diogo Coelho, cuja carta de 1573 já apresentámos nas páginas precedentes. Como vimos, apesar das suas dúvidas, o padre Coelho acabou por cumprir a tarefa que os inquisidores lhe tinham dado. Mas é muito provável que antes tivesse posto em prática uma estratégia alternativa à da denúncia inquisitorial, usando os privilégios da Companhia, ou satisfazendo ao preceito da correcção fraterna. Penso que assim se deva interpretar o seguinte passo, já acima referido: "como medico humano quis curar com brandura o doente que achei desposto, que bem entendi poder-se fazer com maior satisfação de vs. ms. e quietação por ventura do penitente se logo o remetera a vs. ms., mas como digo a

(130) Carta de Pedro da Silva por comissão do reitor do colégio de Coimbra, Coimbra, 1 de Setembro 1563, em ARSI, Lus. 52, fls. 29-32v, em particular fl. $30 v$. 
humanidade me venceo e zelo que tinha e tenho de ver a todos ajudados e alevantados com brandura quanto puder ser"(131).

Após o fim do concilio de Trento a questão dos poderes de absolvição no foro da consciência foi debatida frequentemente. A faculdade dos bispos foi posta em dúvida pela bula In coena Domini de 1568, que reservava a remissão dos pecados elencados nela ao Papa e aos seus delegados, os inquisidores do Santo Ofício. A incerteza ficou e foi ainda maior no caso da Companhia de Jesus, cujos antigos privilégios, ao menos em Portugal, não tinham sido revogados. Entre os jesuítas não faltou, até, quem tentasse aproveitar a confusão de poderes para obter uma confirmação das faculdades concedidas à Companhia. Assim fez, em 1571, o padre Luís de Vasconcelos, que residia no colégio de Angra, nos Açores. O seu pedido surgia também da particular situação da ilha, que ficava distante do continente e tinha graves faltas nas instituições eclesiásticas locais. Numa carta enviada ao padre geral Francisco de Borja, em Janeiro de 1571, escrevia Luís de Vasconcelos:

“Como esta isla está trezientos legoas, o perto dellas, afastada de Portogal, vea V. P. si converna que alguno de los padres tenga licencia para poder absolver de heresia in foro conscientiae en algun caso secreto, como podria ser si una donzella, o otra muger casada, caese en el, maiormente aviendo dubda si el obispo puede absolver del, porque puesto que el concilio Tridentino aya dado poder a los obispos que lo puedan absolver, dubdan aca varones doctos si el papa revoga la tal licencia por la bulla de la coena, en la qual diz Su Santidad que ninguno absolva de aquellos casos, si no fuere in articulo mortis, revogando para esto qualquer decreto del concilio general, por onde dizen que no es seguro, ni licito al obispo absolver de haeresia hasta que Su Santidad declare esta dubda, y ansi puede una pobre muger quedar por muchos años escomungada y apartada de los sacramentos con mucho peligro de su anima, y de su salud espiritual. Vea V. P. si alguno de los professos que aqui aora estan terna este poder para algun caso secreto"(132).

(131) Carta do padre Diogo Coelho aos inquisidores de Coimbra, Bragança, 6 de Janeiro de 1573, em BdA, 49-IV-26, "Vários papeis sobre a Inquisição", doc. 3.

(132) Carta do padre Luís de Vasconcelos ao padre geral Francisco de Borja, Angra, 30 de Janeiro de 1571, em ARSI, Lus. 64, fls. 156-157v, em particular fl. $156 v$. 
Poucos meses depois, no início de Julho, um outro jesuíta que então se achava em Angra, Pedro Gomes, escreveu uma carta a Diego Mirón na qual se voltava a afrontar a questão dos poderes de absolvição no foro da consciência em relação a um caso concreto:

"Padre nuestro, estos dias passados vino de Roma, pareçeme que del penitençiario mayor do papa, un breve a esta insula en que estamos en que dispensava con hun hombre no foro da conciençia neste caso: avjendo una muger conversado con hun hombre vino despues con su ignorancia a casar con hun hermano de aquel hombre y asi estuvo muitos anos casada con el, ecc. Suplico a Su Santidad dispensase con ellos para poder estar casada com este marido que tiene, no obstante el impedimento del cuñadio que tenia antes de casar, y vinole aora la dispensaçion, mas venia remjtida a hun doctor en teologia o en canones, para que este in foro conciençie dispensase ela. Vino el caso a nos e como nestas insulas no aya doctor nj pareçe que lo avera y las personas são tan pobres [...] pidieronme que escriviendo a Roma qujsese pedir algun padre se se poderia [...] que aquella dispensacion que venja dirijida a un doctor, vistos que aquj no lo ay, se remitta al rector del colegio, ou a qualquiera confesor en su absençia, porque los padres tienen cujdado desta penjtiençieria por amor de nuestro Señor, por la pobreza destas personas, e ja que con sempliiçidade les descubrieron esto y ellas estan en mal estado, que se puede hazer alguna cousa que $V$. R. lo encomiende a quien bien le pareçiere, porque en esto haga alguna diligençia, no obstante que al mesmo que me dio la letra avise que tornase a hazer otra peticion para que aquella letra venga endereçada al ordinario o a quien pareçiere, ja que aqui no ay doctor"(133).

(133) Carta de Pedro Gomes ao padre Diego Mirón, Angra, 6 de Julho de 1571, ibidem, fls. 204-205v; em particular fls. 204v-205. Sobre a presença da Inquisição nos Açores ver Paulo Drumond Braga, A Inquisição nos Açores, Ponta Delgada, Instituto Cultural da Ponta Delgada, 1997. A p. 159 encontra-se uma breve referência ao papel dos confessores jesuítas durante as visitas inquisitoriais, especificamente em relação à visita dos Açores nos anos 1619-1620. Sobre esta visitação ver também Célia Maria Ferreira Reis, "A Inquisição em Angra (1575-1620)", Islenha, vol. 8, Jan.-Jun. 1991, pp. 39-54. A pesar do caso citado no texto, a situação das ilhas devia favorecer várias formas de colaboração dos jesuítas com a Inquisição. Na Madeira, por exemplo, o reitor do colégio jesuíta de S. João Evangelista, fundado em 1570, contribuiu, durante os últimos decénios do século XVI, 
Apesar dos exemplos acima referidos, havia outros jesuítas que aproveitavam da confissão sacramental para reforçar a capacidade de penetração do Santo Ofício. Na segunda metade dos anos sessenta, por exemplo, tiveram lugar os processos contra dois sacerdotes rivais de Elvas, André Fialho e João Gonçalves, ambos acusados de solicitação no acto da confissão, um crime sobre o qual, naquela altura, a Inquisição ainda não tinha jurisdição, mas que o cardeal infante conseguiu julgar perante os inquisidores de Lisboa ${ }^{(134)}$. Durante o mês de Abril de 1568, Manuel Cerqueira, promotor do auditório eclesiástico de Évora, em cujo cárcere se encontrava preso João Gonçalves, deslocou-se a Elvas para recolher os testemunhos da acusação e da defesa e ratificar os depoimentos. Toda a estratégia do promotor procurava demonstrar a culpa do réu e contava com o apoio dos parentes e amigos do outro acusado, André Fialho, inimigo de Gonçalves, também porque este o tinha denunciado perante a Inquisição. Nesta represália organizada, de que o Santo Ofício procurou tirar vantagem, participou também o padre Manuel Sequeira, um jesuíta do Colégio de Évora, que tinha o cargo específico de pregar e confessar na arquidiocese. Como declarou Gonçalves, num libelo de defesa apresentado aos inquisidores de Lisboa, em Janeiro de 1569, o principal partidário de Fialho, Estêvão Mendes, gozou da colaboração de padre Sequeira que no confessionário "induzia as testemunhas e pesoas que fosem testemunhar e jurar contra elle reo"(135). Aliás, a história da perseguição do crime de solicitação no acto da confissão em Portugal

\footnotetext{
para o controlo sobre a fé dos cristãos novos, juntamente com o vigairo geral. Cf. Maria do Carmo Jasmins Dias Farinha, A Madeira nos Arquivos da Inquisição, Funchal, 1986, pp. 3-5. Outros dados sobre a actividade dos confessores jesuítas durante as visitas inquisitoriais encontram-se em Fernanda Olival, "A visita da Inquisição à Madeira em 1591-92", em Actas. III Colóquio Internacional de História da Madeira, Funchal, Secretaria Regional da Educação e Cultura-Centro de Estudos de História do Atlântico, 1993, pp. 493-519; em particular pp. 501-502. (134) Ver o processo de André Fialho (1567-1570), em ANTT, Inquisição de Lisboa, processo 1062, e o do João Gonçalves (1568-1570), em ANTT, Inquisição de Lisboa, processo 12645.

(135) Libelo de defesa de João Gonçalves apresentado aos inquisidores de Lisboa na primeira metade de Janeiro de 1569 . O documento consta de 12 folhas não numeradas e encontra-se nas actas do processo a seguir à f. $354 v$. $O$ passo citado acha-se na f. $10 v$ do dito libelo (a numeração é minha).
} 
(um crime que a Inquisição procurou ter sob sua jurisdição, pelo menos a partir da metade dos anos sessenta, por forma a adquirir uma maior capacidade de controlo sobre a acção dos confessores, mas que somente alcançou em 1599) está intimamente relacionada com a Companhia de Jesus. Um dos primeiros confessores que se conhece acusado de solicitação foi o jesuíta do Colégio de Coimbra, padre António Martins, delatado em 1567, e contra o qual o Santo Ofício não chegou a iniciar processo. Ojesuíta tinha sido anteriormente denunciado ao superior, que o castigou, proibindo-o de continuar a administrar o sacramento da penitência ${ }^{(136)}$. A confissão de mulheres era um problema que preocupava muito a Companhia. Durante os anos setenta, em muitas cartas acham-se instruções e normas para evitar que os confessores pudessem praticar actos ilícitos com as penitentes ${ }^{(137)}$. Tratava-se de defender a reputação da Companhia, a tal ponto que, quando, em 1575, se divulgou a notícia que em Espanha o irmão de padre Diego de Sepúlveda, vice-reitor do colégio de Bragança, estava preso pela Inquisição por crime de solicitação, foi necessário remover do cargo o jesuíta, porque já havia algumas suspeitas também sobre alguns excessos cometidos por ele, mas sobretudo porque, se o irmão de Sepúlveda tivesse saído no auto-da-fé e se tivesse sabido na cidade, a infâmia e o escândalo teriam envolvido a Companhia. Numa carta reservada enviada ao padre geral Everardo Mercuriano escrevia o provincial lusitano:

"El padre Diego de Sepulveda, vicerector de Bragança, aunque es buen hombre y se moveria por buen fin, tenia algun excessos con algunas divotas, de que el collegio andava disedificado, y siendo avisado por el padre Jorge Sarrano no se emmendava. Dizese que esta preso por la inquisicion un su hermano sacerdote por solicitar una su confessada y es probable que salga cedo al acto publico de la inquisicion. Temi que, publicandose este caso del hermano y durando la familiaridad que el

(136) Ver a denúncia de Maria Borges apresentada ao inquisidor de Coimbra Manuel de Quadros, datada a 12 de Fevereiro de 1567, em ANTT, Inquisição de Coimbra, Livro 624, fls. 410-411v.

(137) Ver por exemplo a carta de padre Miguel de Torres ao padre geral Everardo Mercuriano, Évora, 28 de Agosto de 1574, em ARSI, Lus. 66, fls. 241-242v; a carta de padre Manuel Álvares ao padre geral Everardo Mercuriano, Lisboa, 25 de Novembro de 1575, em ARSI, Lus. 75, fls. 254-255v. 
padre tenia con las devotas, se llevantasse en Bragança alguna murmuracion o escandalo y por esso parecia necessario sacar al padre de Bragança con tiempo, para que, quando se publicara el caso del hermano, estee ya estincto el del padre"(138).

Após se ter deslocado para Coimbra e depois para Lisboa, finalmente, o padre Sepúlveda conseguiu ir para Roma ${ }^{(139)}$. Outras acusações provieram também da campanha contra os jesuítas levantada por frei Alonso de la Fuente em 1576. Entre os vários pontos dos seus memoriais havia um que afirmava que eles tinham a opinião errada "que los tactos exteriores con mortificación no son peccado, y ansi los maestros tractan suciamente con las discípulas, diciendo que aquello no es peccado" e outro que declarava a presumida conviç̧ão dos jesuítas "que sus discípulas no se han de confessar con otros confessores"(140). Pelo contrário, na documentação relativa ao episódio de frei Alonso de la Fuente, descobre-se uma notícia acerca da acção da Companhia contra o crime de solicitação. Numa carta de 1576 escrita pelo cardeal infante D. Henrique ao inquisidor geral de Espanha Gaspar de Quiroga declarava-se:

"he muito grande inconveniente e contra o serviço de nosso Senhor e honra dos Regnos publicar facilmente que ha heresias e querer fazer de cousas, que polla ventura se fazem por cometter peccados de carne, fazelhas que são heresias e condenalas por taes e de sua própria authoridade. Em este Regno se acharão tres ou quatro sacerdotes confessores que cometião estos peccados de carne, assi na confissão como fora delle, e tinhão ajuntamente con suas confessadas e lhes dizião que

(138) Carta do padre provincial Manuel Rodrigues ao padre geral Everardo Mercuriano, sem data, mas escrita depois do dia 6 de Janeiro de 1575, em ARSI, Lus. 66, fl. 364rv, em particular fl. 364.

(139) Sobre o caso de padre Diego de Sepulveda ver a carta reservada de padre Diego de Sepulveda ao padre geral Everardo Mercuriano, Lisboa, 10 de Julho de 1575, em ARSI, Lus. 67, fls. 123-123v; a carta do padre provincial Manuel Rodrigues ao padre geral Everardo Mercuriano, Coimbra, 8 de Agosto de 1575, ibidem, fls. 160-161v; por fim, a carta sempre de Rodrigues a Mercuriano, Braga, 27 de Setembro de 1575, ibidem, fls. 202-203v.

(140) Memorial de frei Alonso de la Fuente para frei Estêvão Leitão, entregue no dia 18 de Março de 1576, publicado em Alvaro Huerga, ob. cit., vol. I, pp. 456-465 , em particular p. 462. 
os não confessasem, que não era peccado, pera se não saber o que elles fazião; e não tinhão contra cousa de heresia. E o principal destos foi descuberto por padres da Companhia de Jhú., que vierão a saber o que elle fazia"(141).

Até agora esta é a única menção conhecida sobre este caso, mas não se conhece a identidade do confessor culpado, nem se sabe se foi processado pela Inquisição.

Outras duas acusações de frei Alonso de la Fuente contra os padres da Companhia eram "que algunos de ellos revelan las confesiones, y es cosa mui usada entre esta gente" $\mathrm{e}$ "que algunos piden el cómplice del pecado para dar corrección" ${ }^{\prime(142)}$. As duas práticas estavam relacionadas entre si e, sobretudo em Espanha, foram objecto de encontros e debates que se prolongaram até o fim dos anos Oitenta. Em Portugal o problema atingia sobretudo a vida interna da Companhia. Numa carta enviada ao geral jesuíta, em 1573, o padre Manuel Rodrigues contava: "Entre algunos de casa y de fuera anda una imaginacion que llega a murmur que no se guarde exactamente el sigillo de las confessiones de los nuestros, lo qual a muchos de casa dà recelos de confessarse con superiores o consultores, y a algunos de fuera principio de escandalo: bien veo ser esto imaginacion aunque no sin fundamentos" ${ }^{\prime(143)}$. No fim do ano seguinte, durante o momento mais polémico da luta para a eleição do novo provincial, Rodrigues escrevia novamente uma carta sobre o assunto ao padre geral: "en San Roque andan tristes y hazen poco y [...] todo este nace de las desconfianças que con ellos se usan, las quales entienden personas de fuera. Tengo entendido que estas cosas no proceden solamente del p. provincial, sino tambien del p. preposito, que parece aver tomado de la doctrina e humor que estos años corre. Tambien me an dicho que los principales padres de San Roque recusan ser

${ }^{(141)}$ Carta do cardeal infante D. Henrique ao inquisidor geral de Espanha Gaspar de Quiroga, Évora, 24 março de 1576, publicado ibidem, pp. 608-609.

${ }^{(142)}$ Memorial de frei Alonso de la Fuente para frei Estêvão Leitão, entregue no dia 18 de Março de 1576, publicado ibidem, pp. 456-465, em particular p. 462.

(143) Carta de padre Manuel Rodrigues ao padre geral Everardo Mercuriano, Coimbra, 4 de Abril de 1573, em ARSI, Lus. 65, fls. 177-178v, em particular fl. 177. Sobre a questão ver também Francisco Rodrigues, ob. cit., t. II, vol. 1, pp. 581-582. 
confessores de los hermanos porque no se atreven guardar sigillo con el p. provincial $[\ldots]^{\prime \prime(144)}$.

A quebra do sigilo da confissão era oficialmente proibida, mas o caso da heresia apresentava algumas excepções ${ }^{(145)}$. Os inquisidores, normalmente, respeitavam o segredo do foro penitencial, mas às vezes a tentação do recurso às informações de que dispunham os confessores era muito forte. E havia sacerdotes que colaboravam de boa vontade, também entre os jesuítas. Existiam várias estratégias para rodear a probição e observar formalmente o sigilo. Por exemplo, podiam-se fornecer notícias úteis, calando o nome dos penitentes ou dos culpados e outros pormenores, pelos quais fosse possível reconhecer a identidade das pessoas às quais se referia o confessor. Assim fez, em 1597, um padre jesuíta para esclarecer uma situação de notável confusão, quando a seguir a capturas de cristãos-novos judaizantes, feitas em Évora e Coimbra, o Santo Ofício foi atingido por murmurações e polémicas acerca dos falsos testemunhos que se receberiam nos tribunais. É o que se depreende por uma carta do bispo de Elvas, António Matos de Noronha, naquela altura inquisidor geral:

"Vi a sua carta de 18 do presente em que dizem como os christãos novos reconciliados que sairão no Auto passado andão na doctrina, e que tem dado ordem pera os confessarem e tomarem o Santissimo Sacramento. E que por elles todos agora dizerem nas confissões sacramentais, como sempre foi seu costume, que nunqua forão judeus e que tudo o que tinhão confessado no Santo Officio era falso, os padres da Companhia que são seus confessores tiverão grande scrupulo ao menos em lhe darem a comunhão, e que os avisarão disto pedindo-lhes o remediassem. E que poserão este caso em mesa, com os deputados, e se assentou que os padres os confessassem, mas que lhe não dessem o

(144) Carta de padre Manuel Rodrigues ao padre geral Everardo Mercuriano, sem lugar nem data, mas escrita antes de Novembro de 1574, em ARSI, Lus. 66, fls. $365 \mathrm{rv}$, em particular fl. 365 .

${ }^{(145)} \mathrm{O}$ problema da quebra do sigilo pelos confessores em Portugal explodiu durante o século XVIII. Ver António Pereira da Silva, $A$ questão do sigilismo em Portugal no século XVIII. História, religião e política nos reinados de D. João V e D. José, Braga 1964; Adriano Prosperi, "Il sigillo infranto: confessione e inquisizione in Portogallo nel '700", em Idem, L'Inquisizione romana. Letture e ricerche, Roma, Edizioni di Storia e Letteratura, 2003, pp. 413-434. 
Santissimo Sacramento. E me pedem os avise do que sobre este negocio devem fazer. $O$ que parece que convem que se faça he que se estes reconciliados dizem fóra das confissões nunqua forão judeus e que o que confessarão no Santo Officio era falso, que se faça disso sumario avendo testemunhas que lho ouvissem dizer, e se proceda contra elles conforme a direito. Mas se isto se sabe somente por via de confissões sacramentais, devem avisar aos padres que fação seu officio com elles, e os aconselhem como lhes parecer que mais convem a serviço de Deos Nosso Senhor e salvação de suas almas, significando-lhes que manhosa he esta gente $e$ as invenções que buscão por todas as vias pera se acreditarem e desacreditarem o Santo Officio"(146).

Às vezes, por fim, havia confessores que não tinham receio de quebrar inteiramente o sigilo sacramental para denunciar um suspeito herege à Inquisição. Desta maneira agiu, em 1588, o padre Luís da Cruz, jesuíta do colégio de Bragança, que numa carta enviada aos inquisidores de Coimbra não hesitou em violar o segredo do que lhe tinha dito em confissão um Luís de Paiva, acerca de uma sua cunhada cristã-nova, que o jesuíta não tardou a identificar com uma Leonor de Valhadolid. Como escreveu ao Santo Ofício, "este Luis de Paiva veo ter comigo e disse que vinha tratar comigo hum caso de confissão em segredo, e não foi o segredo tal que não possa e deva dize-llo a vv. mm". O trecho da carta merece uma leitura mais ampla, porque se esboça o perfil dum típico confessor ao serviço da Inquisição. Assim começava o jesuíta: "Como esteja tão longe esse Santo Tribunal, não occorre outro meo mais accomodado pera recorrer nas duvidas que se offerecem que trata-las com vv. $\mathrm{mm}$. por carta dando conta do que parece que convem, como agora farei nesta". E prosseguia: "Huma molher da nação, chamada Breatis Nunes, a qual neste collegio se confessa muitas vezes", "veo ter comigo e tratando

(146) Carta do bispo de Elvas António Matos de Noronha, Lisboa, 27 de Novembro de 1597, publicada em Joaquim Romero Magalhães, "Em busca dos 'tempos' da Inquisição (1573-1615)", Revista de História das Ideias, vol. 9, 1987, pp. 191-228, em particular pp. 224-225. O autor não indica se a carta foi enviada aos inquisidores de Évora ou aos de Coimbra. Mais em geral, sobre o episódio ver João Lúcio de Azevedo, História dos cristãos novos portugueses, Lisboa, Livraria Clássica Editora, 1975 [1ª ed. or. 1921], pp. 137-138. 
alguns pontos da sua consciência, tudo o que della pude collegir pera referir a vv. mm. he o seguinte". Em seguida, contavam-se as discórdias surgidas entre Beatriz Nunes e um casal de cristãos-novos, Henrique Fernandes e Leanor de Valhadolid, depois de Beatriz Nunes ter apresentado um testemunho ao inquisidor Jerónimo de Sousa durante a visita inquisitorial do Trás-os-Montes em 1583, em que ela acusara o casal de judaizar. Continuava ainda o padre Luís da Cruz:

"E confirindo humas cousas com outras ajuntarei aqui huma circumstancia. Está nesta cidade hum Luis de Paiva, homem honrado, christão velho, pobre. Este esta casado com huma irmã desta Lianor de Valhadolid. Avera mais de hum anno que este Luis de Paiva veo ter comigo e disse que vinha tratar comigo hum caso de confissão em segredo, e não foi o segredo tal que não possa e não deva dize-llo a vv. mm. O caso foi este. Disse-me pouco mais ou menos o que se segue. Tenho huma cunhada, christã nova, etc. Então continuou dizendo. Há poucos dias que estando minha cunhada em hum forno e, metendo-se hum pão, huma moça disse: 'Filho de Deos, que pão tamanho!'. Acudio a cunhada: 'Filho de Deos, filho do demo!'. Estava então o bispo em visitação per sua pessoa, e porque as palavras em pessoa sospeitosa são as ditas, eu lhe disse $o$ que avia de fazer: ir ao bispo e leva-la que ella propria se accusase, $e$ devia de $o$ fazer porque as pessoas que a ouvirão se schandalizarão $e$ estavão pera ir a visitação e fazer denunciação. Pareceo-me que o bispo, como he de creer, faria seu officio e sendo o caso de vv. mm. avisaria esse Santo Tribunal. Não sei o que passa. Mas agora, cumprindo o que escrevi com esta minha narração, acho que pode ser a dita Lianor de Valhadolid. $\mathrm{E}$ assi escrevo tudo a vv. mm. que verão o que importa. E tanto mais devemos de ca fazer esta obrigação, quanto sentimos que esta terra esta solapada e que realmente ha judeus"(147).

A ameaça da quebra do sigilo para usos inquisitoriais era notável e grave, mas nunca se tornou uma prática frequente. De qualquer maneira, o recurso aos confessores jesuítas podia-se revelar uma arma extraordinária na mão dos inquisidores.

(147) Carta do padre Luís da Cruz aos inquisidores de Coimbra, Bragança, 18 de Julho de 1588, em ANTT, Inquisição de Coimbra, maço 58, doc. 95. 
Finalmente, existia uma outra área em que a colaboração entre o Santo Ofício e a Companhia era cada vez maior: a censura dos livros. Os poderes que os jesuítas foram adquirindo ao longo dos anos neste âmbito da actividade da Inquisição acrescentou ainda mais a capacidade de controlo da cultura por parte da Companhia em Portugal. Lembre-se que, já desde 1559 , os jesuítas geriam de forma totalmente autónoma a segunda universidade do reino, a de Évora. No início dos anos Setenta o cardeal infante D. Henrique promoveu uma forte intervenção inquisitorial no mundo dos livros. A 19 de Abril de 1571 mandou fazer visitações às livrarias públicas e promulgar desde os púlpitos das igrejas o édito em que revogava todas as licenças de leitura de livros proibidos outorgadas no passado e obrigava a entregar aos inquisidores o rol dos livros que possuíam ${ }^{(148)}$. Pela documentação relativa à Inquisição de Évora e de Coimbra compreende-se que a operação se inseria, provavelmente, numa mais ampla estratégia de reorganização dos equilibrios de poderes entre o Santo Ofício e as instituições académicas, com a importante mediação dos jesuítas, cuja hegemonia cultural nas duas cidades universitárias era cada vez maior. No fim de Janeiro de 1572, de facto, D. Henrique enviou aos inquisidores de Évora e de Coimbra a faculdade de conceder licenças para imprimir as conclusões das universidades e dos colégios: "Fazemos saber que avemos por bem e nos praz que os inquisidores d'Evora e de Coimbra possão dar licença pera se poderem imprimir as conclusões das universidades e collegios. E sendo necessario, as mandarám primeiro ver pellas pessoas que lhe parecer. E esta queremos que valha, posto que não seja passada por nosso Concelho". Os jesuítas, todavia, gozavam dum privilégio de isenção em relação à licença inquisitorial, como se presume por uma nota na margem que diz: "os da Companhia possam mandar emprimar"(149). Tratava-se dum considerável reconhecimento por parte da Inquisição da autoridade teológica e cultural da Companhia. Contudo, os jesuítas tentavam manter uma imagem de autonomia em

(148) Uma cópia do édito enviado ao Santo Ofício de Lisboa em 19 de Abril de 1571, juntamente à minuta duma carta de acompanhamento do cardeal infante D. Henrique escrita em Sintra no dia 19 de Julho de 1571, acha-se em ANTT, Conselho Geral do Santo Ofício, Livro 92, fls. 187-188.

(149) Provisão do cardeal infante D. Henrique, Almeirim, 31 de Janeiro de 1572, em ANTT, Inquisição de Évora, Livro 72, fl. 121. 
relação ao Santo Ofício, como mostra a reacção dos padres à pretensão de $\mathrm{D}$. Henrique de celebrar as reuniões do Conselho Geral no colégio da Companhia de Évora, quando o cardeal infante se achava na cidade alentejana. Em Março de 1573, o padre Jorge Serrão escrevia a Juan Alfonso de Polanco:

"La casa de Consejo Real de la Inquisicion, que alla se escrevio tenerse en este collegio, se ordeno por el cardenal y dello se dio aviso alla sin que yo lo supiesse, por estar en Coimbra. $Y$ veniendo a este collegio procure luego impedirlo y el cardenal me hablo en ello diziendo que, mientras el posava en este collegio, no podia el dicho tribunal estar en otra parte por ser inquisidor mayor y como presidente ser necessario hallarse muchas vezes presente. Ny el cardenal tiene en esta ciudad otros palacios, sino la habitacion que para sy hizo en este collegio, y seria cosa difficil a un principe y fundador tal pedirle que se saliesse de sus casas $y$, como el se sirve pelas eschuelas, no ay tanta occasion de inquietarnos"(150).

Por fim, a Companhia inclinava-se aos pedidos do inquisidor geral. A confiança de D. Henrique para com os jesuítas foi sempre muito profunda a partir dos anos Cinquenta. O cardeal infante não hesitou em estender alguns dos seus poderes aos padres da Companhia. Assim foi, por exemplo, em relação à licença de ler os livros proibidos. No fim de 1560, o inquisidor-geral obteve a faculdade de ler os livros de hereges e a possibilidade de delegar esta licença ${ }^{(151)}$. D. Henrique delegou a licença aos jesuítas que puderam ler livros de autores hereges e também as obras de autores aprovados que eram proibidas porque referiam os erros dos hereges, embora fosse apenas para os criticar e condenar. Foi provavelmente graças a uma precoce concessão da delegação que eles puderam obviar a regra do índice português de 1561 em que se estabelecia: "Tambem

(150) Carta do padre provincial Jorge Serrão ao padre vigairo geral Juan Alfonso de Polanco, Évora, 2 de Março de 1573, em ARSI, Lus. 65, fls. 136-137v, em particular fl. 136.

(151) Ver o breve Singularis, E eximia enviado pelo papa Pio IV ao cardeal infante D. Henrique, Roma, 2 de Dezembro de 1560, publicado no Collectorio de diversas Letras Apostolicas, Provisões Reaes, e outros papeis, em que se contém a Instituyção, $\mathcal{E}$ primeiro progresso do Sancto Officio em Portugal, E varios Privilegios que os Summos Pontifices, E Reys lhe concederão, Lisboa, nas casas da Sancta Inquisição, 1596, fls. 52v-53. 
por quanto temos por perigoso leerem todos hos livros de authores catholicos em que se reprovão \& confutão errores de lutheranos \& de outros hereges, mandamos que ninguem hos tenha sem licença de quem pera iso nossas vezes tiver" ${ }^{\prime 152)}$. A licença consentia aos jesuítas ler livros de importância fundamental para o estudo e o ensino da teologia católica. É provável que o cardeal infante tenha renovado a delegação aos padres da Companhia para eles exercerem mais livremente as próprias funções de vanguarda intelectual da Contra-Reforma em Portugal. Era uma medida necessária, porque apesar do índice tridentino de 1564 não conter a regra do índice português de 1561, o cardeal infante mandou observá-la de igual maneira nos anos seguintes ${ }^{(153)}$. Por isso, quando no fim dos anos setenta chegou de Roma a ordem de os padres não usarem a licença que tinham, a resposta de Portugal foi muito clara com referência aos graves inconvenientes que surgiriam:

“Recebi la de V. P. de 21 de Março. Y quanto a no usar de la faculdad que elRey quando era inquisidor mayor nos dio para usar de libros proibidos haremos como V. P. escrive. Esto se me offrece de proponer que $S$. A. siendo nuncio y inquisidor mayor prohibio ciertos libros que no estan prohibidos en el catalogo del Concilio Tridentino, entre los quales prohibio los que escriven contra herejes poniendo en forma las razones de los herejes, y por esta causa ay entre nos escrupulo de leer Soto de natura, et gratia, y usar de las partes de Santo Tomas que tienen iuntos opuscolos de Caietano, y de algunos otros buenos autores, que ponen en forma razones de herejes. Si pareciesse a V. P. dexarnos usar de la licencia de S. A., o que la pidamos de nuevo al inquisidor mayor para los libros

(152) Provisão dada pelo cardeal infante D. Henrique sobre a execução do Rol de livros defesos de 1561, em Rol de Livros defesos, Lisboa 1561, fls. 2-3. O documento é também publicado em Índice dos livros proibidos em Portugal no século XVI, Apresentação, estudo introdutório e reprodução fac-similada dos índices, por Artur Moreira de Sá, Lisboa, Instituto Nacional de Investigação Científica, 1983, pp. 76-78; em particular p. 78.

${ }^{(153)}$ Em 1564, de facto, o Index librorum proibitorum tridentino foi publicado em Portugal com uma carta introdutória do cardeal infante D. Henrique, que acabava revogando "quoscumque alios librorum prohibitorum Indices, qui ante hac prodiere, ut huic duntaxat deinceps integre et indubitata fides habeatur" (Carta do cardeal infante D. Henrique, Lisboa, 15 de Outubro de 1564, publicada ibidem, pp. 82-83). 
prohibidos en este catalogo particular deste Reyno, seria para nos grande alivio. Tambien en los escritos de letra de mano ay muchos escrupulos, de que estavamos quietos con aquella licencia de S. A."(154)

\section{Conclusão}

A imagem da Companhia nos últimos dois decénios do século XVI era a de uma instituição completamente integrada nas esferas do poder do reino lusitano. Nas duas universidades de Coimbra e de Évora a presença jesuítica era muito forte. Apesar de Portugal ter estado sob a dominação espanhola, a Inquisição portuguesa ficou absolutamente independente da sua vizinha ibérica e, até ao fim do século, manteve relações muito estreitas com a Companhia de Jesus. Os padres continuavam a obra de assistência aos condenados dos autos-da-fé. Mas muitos outros cargos se conferiam aos jesuítas na Inquisição ${ }^{(155)}$.

Em 1585, o padre Pedro da Fonseca pediu ao geral Acquaviva impetrasse ao Papa que os da Companhia não pudessem ser compelidos pelos inquisidores a desempenhar ofícios da Inquisição. Acquaviva respondeu que o Papa tinha já concedido um breve de isenção à Companhia ${ }^{(156)}$.

(154) Carta do padre Manuel Rodrigues ao padre geral Everardo Mercuriano, Coimbra, 30 de Maio de 1579, em ARSI, Lus. 68, fls. 148-149v, em particular fl. 148.

(155) Sobre estes cargos afirma, com intentos apologéticos, Francisco Rodrigues, ob. cit., t. II, vol. 1, p. 511: "Cargos no tribunal do Santo Ofício ou particulares incumbências também uma vez ou outra os aceitavam, se lho pediam, num tempo em que se olhava para êsse tribunal, como para uma santa instituição".

(156) Sobre o episódio, ver ibidem. O padre geral referia-se à bula Satis superque, promulgada pelo papa Gregório XIII, Roma, 10 de Setembro de 1584, em que se afirmava: "neminem ex Religionis sub praedictae Societatis obedientia degentem, a quibusvis, quacumque ecclesiastica vel saeculari dignitate seu auctoritate fungentibus, etiam si S. R. E. Cardinales, Patriarchae, Archiepiscopi, Episcopi vel alii Antistites et Praelati, nec non synodi, Communitates et Capitula quaecumque, aut officii haereticae pravitatis Inquisitores, ac Commissarii vel Iudices, tam ipsius officii, quocumque illi nomine censeantur, quam alii ordinarii vel delegati, vel etiam Imperator, reges et alii saeculares Principes, ad quodvis munus, officium vel exercitium obeundum, etiam praetextu quod alii inibi non inveniantur a quibus adiuvari possint, absque expresso sui Superioris consensu ac etiam mandato destinari, adigi vel cogi posse" (em Institutum cit., vol. I, pp. 99-100; em particular p. 99). 
Talvez se tratasse de uma tentativa de estorvar as tarefas na censura dos livros, como parece poder-se depreender pela carta que, em 1587, o padre Sebastião Morales escreveu ao padre geral:

"Por correo passado me escrevio V. P. que holgaria que el colegio de Coimbra fuesse libre de la occupacion que tiene de rever los libros por parte de la inquisition. Yo lo deseo mucho por el trabajo que los nuestro alli tienen, y aqui tambien en Evora, adonde se haze lo mismo, y ya en tiempo del arcobispo de Lisbona inquisidor mayor se procuro escuzar este trabajo, pero no se pudo, y mucho menos se podra aora sin sentimiento y offension del cardenal que es inquisidor mayor, a cuia peticion se haze esto. Y quanto a nos hazer este officio mal quistos, no lo pienso. Contudo iuzgando V. P. otra cosa, harsea lo que ordenara"157.

Mas, em todo o caso, os jesuítas continuaram a admitir o exercício de cargos no Sagrado Tribunal. A Inquisição, de facto, chegou a esboçar um novo projecto de envolvimento dos jesuítas. Após a morte do padre Leão Henriques (1589) e do padre Jorge Serrão (1590), que tinham servido como deputados no Conselho Geral, em 1592, o secretário do supremo órgão do Santo Ofício foi ter à Casa de S. Roque e comunicou ao prepósito, padre Manuel Sequeira, que Sua Majestade queria que a Companhia lhe desse seis padres para ajudar na mesa da Inquisição de Lisboa, Coimbra e Évora, três para revisores de livros e outros três para deputados. Não se sabe quem aconselhou a proposta ao rei, ou melhor ao cardeal arquiduque, então inquisidor-geral em Portugal, mas é certo que, pouco tempo antes, Martim Gonçalves da Câmara tinha terminado a visita geral aos três tribunais inquisitorias do reino e, no remate dela, escrevera um capítulo a propor que se pusessem naqueles ofícios padres da Companhia ${ }^{(158)}$. Como se depreende por uma carta de Pedro da Fonseca, datada a 8 de Agosto de 1592, Gonçalves da Câmara declarava que a Companhia não devia de modo nenhum deixar de aceitar o que se lhe oferecia, não somente pelos perigos que as coisas da fé corriam em Portugal,

(157) Carta do padre Sebastião Morais ao padre geral Everardo Mercuriano, Évora, 21 de Fevereiro de 1587, em ARSI, Lus. 70, fls. 73-74v, em particular fl. 74.

(158) Sobre a visita de Martim Gonçalves da Câmara (1591), ver Francisco Bethencourt, História das Inquisições. Portugal, Espanha, Itália, Lisboa, Círculo de Leitores, 1994, pp. 171-172. 
mas também porque tomariam mal estes príncipes se a Companhia não quisesse ajudá-los desta maneira. $O$ padre Manuel de Sequeira reuniu os principais padres que se achavam em Lisboa (Francisco de Gouveia, Jerónimo Dias, Pedro da Fonseca, Jerónimo Cardoso e Luís de Cerqueira) e, depois de muito discutir, assentaram que era bem se aceitasse o que Sua Alteza propunha, por ser coisa de grande serviço de Deus e crédito da Companhia. Também o padre provincial João Álvares, que se encontrava em Coimbra, se aconselhou com outros padres do colégio local e acabaram por concordar com a resolução dos de Lisboa. Foram escolhidos os seis padres (Rui Martins ou Francisco de Gouveia como deputados de Lisboa e Pedro Pablo Ferrer como revisor dos livros; Francisco Pereira como deputado em Coimbra e Rui de Góis como revisor; Fernão Rebelo como deputado em Évora e Cristóvão Freire como revisor). Fonseca foi ter com o cardeal arquiduque para lhe comunicar os nomes dos nomeados pela Companhia. Mas, tal como em 1555, a principiada eleição não teve seguimento ${ }^{(159)}$. De qualquer maneira, os jesuítas continuaram a gerir a censura literária. Em Dezembro de 1593, por exemplo, o cardeal Alberto pediu novamente ao vice-provincial Sequeira dois padres, um para revisor de livros, outro para qualificador. Foram nomeados Francisco Pereira e Pedro Pablo Ferrer, que foram com efeito por muito tempo simultâneamente revisores e qualificadores. Opadre Pereira ainda servia nesses cargos em 1614, e Ferrer desempenhou-os pelo espaço de dezasseis anos ${ }^{(160)}$. Sempre aos jesuítas eram confiados

(159) Sobre o episódio ver Francisco Rodrigues, ob. cit., t. II, vol. 1, pp. 512-514. Quando foi ao cardeal arquiduque Fonseca, por insinuação do provincial Álvares, lembrou ao inquisidor geral que o lugar de deputado no Conselho Geral do Santo Ofício estava ainda vago por morte de Jorge Serrão, que o teve por muitos anos, e seria desdoiro para a Companhia dar agora a seus religiosos cargos inferiores, retirando-lhes o superior e de mais importância, em que ela bem merecera, confiando-o a outrem. O cardeal mostrou sentimento de se não ter cometido à Companhia aquele lugar do Conselho Geral, significando que a repulsa não fora sua, mas de Madrid e de novo faria o que pudesse naquele particular (cf. ibidem, p. 514, nota 1).

(160) Ver Francisco Rodrigues, ibidem, pp. 514-515. Ferrer exerceu o cargo inquisitorial, apesar de ser, como já vimos, cristão-novo. Note-se que o douto jesuíta, que entre 1559 e 1577 foi também professor de Sagrada Escritura na Universidade de Évora, escreveu um breve tratado de apologética anti-judaica, que ficou manuscrito, intitulado Confutatio quinque potissimum errorum quibus 
pelos inquisidores os penitentes para que os aconselhassem a confessarem mais inteiramente os seus erros ao Santo Ofício ${ }^{(161)}$. Durante os processos contra os estrangeiros compareciam frequentemente os padres na qualidade de tradutores ${ }^{(162)}$. Conhecem-se casos em que foram nomeados como delegados dos ordinários na mesa da Inquisição ${ }^{(163)}$.

Esta era a situação no início do século XVII. Mas nos anos finais do século precedente, os jesuítas tinham desaparecido do Conselho Geral do Santo Ofício. Era o prelúdio do fim das boas relações que tinham existido durante os precedentes decénios e o anúncio dos conflitos que surgiriam dali a algum tempo. Entretanto, a partir de 1614, por iniciativa do rei Filipe III, à imitação da Inquisição espanhola, foi a Ordem de S. Domingos, que tinha dado, durante o século XVI, importantes inquisidores ao Santo Ofício português, a obter o privilégio de um lugar permanente no Conselho Geral.

Iudaei impudenter dissentiunt a Chistianis. Consultei a cópia conservada na Biblioteca Nazionale di Firenze, Conv. Soppr. I VII 51: "Controversiae nec non Ferrer et Gaspar Commentar. in S. Biblia", fls. 1-33.

(161) Ver por exemplo a confissão de Pêro de Miranda feita na Inquisição de Évora a 11 de Junho de 1571, em ANTT, Inquisição de Évora, Livro 10, fls. 150$-152 v$.

(162) Veja-se por exemplo o processo contra o alemão António Smith (1573-1574), em que interveio como tradutor padre João Vermer. Ver ANTT, Inquisiç̧ão de Évora, processo 6265.

(163) Por exemplo, o padre Jerónimo Dias em substituição do arcebispo de Évora. Ver a carta do Conselho Geral do Santo Ofício aos inquisidores de Évora, Lisboa, 26 de Janeiro de 1595, em ANTT, Inquisição de Évora, fl. 375. 


\section{Apêndice documental}

\section{O testemunho do padre Alfonso Cipriano sobre Isabel Fernandes na Inquisição de Lisboa (1544). (ANTT, Inquisição de Lisboa, processo 9287, f. 137)}

Aos 20 diãs de Março de 1544 annõs, em Lixboa, na casa do despacho da Samta Imquisição, estamdo hi o reverendo padre mestre frei Jorge imquisidor mandou vir perante si a Cepriano, sacerdote de missa que vive na casa de Samt'Antão da Mouraria desta cidade, e lhe deu juramento dos Samtos Evamgelhos que disese a verdade de que fose preguntado e ele asi o prometeo por o dito juramento. It. preguntado se conhecia huma Isabel Fernandez viuva que dizem aver comversado na dita casa, dise que si. It. preguntado que hera o que avia sentido na maneira de viver da dita Isabel Fernandez dise que sentia della ser pessoa de bem e de boa vida e temente a Deos. It. preguntado se sabia que ela se comungasse sem primeiro se comfessar e isso tivesse por costume, dise que avia ano e meo que a não comversava e o tempo que a comversou seria por espaço de dous meses pouco mães ou menos, no qual tempo a ouvio de comfissão algumas vezes e que despõis que ele testemunha viera d'Almeirim que avera nove ou dez meses huum de seus companheiros the disera que ella Isabel Fernandez tomava o Santo Sacramento sem se primeiro comfissar, que bradasse com ella, e que dali a dous ou tres meses ele testemunha a amoestara que o não fizese asi. It. preguntado se avia sabido ou ouvido que ela se afirmasse estar em estado de graça e não aver medo do imferno nem de pecar, dise que a vio com muita esperança e comfiamça em noso Senhor mas que ela nam tivese aquele medo que ele testemunha o nam sabia, e por comcrusão dise que não sabia della outra cousa somente ser ella muito carinhosa e ter gramde amor de noso Senhor e de star de padecer por elle e ter-se por mui vill e ter outros sinães de muito boa cristãa e que se em alguma cousa errar que sera por inoramcia e al não dise. Garcia Lasso o estprevi.
Frater Georgius
Sancti Iacobi ${ }^{(164)}$
Alphonsus Cyprianus

${ }^{(164)} \mathrm{Na}$ transcrição do documento, que não pretende ser uma edição crítica, adoptei um critério de modernização do texto conforme às normas seguintes: actualização da pontuação e do uso das letras maiúsculas e minúsculas; transcrição das letras $i, j$ e $y$ com a letra $i$ e das $c$ e ç com a $c$, quando tal é a forma moderna, deixando-as invariadas no caso contrário; contracção das vogais duplas (eg. aa) conforme à ortografia moderna com acentos; solução das formas contractas e abreviadas; uso de cifras árabes para os números. 